\title{
Relation Between Selected Water-Quality Variables and Lake Level in Upper Klamath and Agency Lakes, Oregon
}

\section{U.S. GEOLOGICAL SURVEY}

Water-Resources Investigations Report 96-4079

Prepared in cooperation with the BUREAU OF RECLAMATION

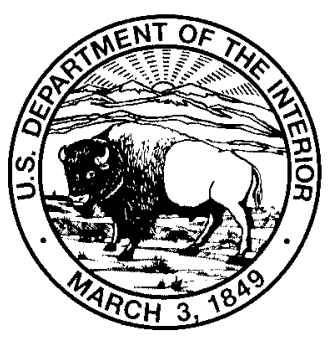




\section{Relation Between Selected Water-Quality Variables and Lake Level in Upper Klamath and Agency Lakes, Oregon}

By TAMARA M. WOOD, GREGORY J. FUHRER, and JENNIFER L. MORACE

U.S. GEOLOGICAL SURVEY

Water-Resources Investigations Report 96-4079

Prepared in cooperation with

BUREAU OF RECLAMATION

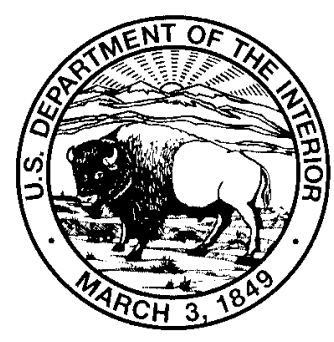

Portland, Oregon 


\section{U.S. DEPARTMENT OF THE INTERIOR BRUCE BABBITT, Secretary}

U.S. GEOLOGICAL SURVEY

Gordon P. Eaton, Director

The use of trade, product, or firm names in this publication is for descriptive purposes only and does not imply endorsement by the U.S. Government.

For additional information write to:

\section{District Chief}

U.S. Geological Survey, WRD 10615 S.E. Cherry Blossom Drive Portland, OR 97216
Copies of this report can be purchased from:

U.S. Geological Survey

Information Services

Box 25286, Federal Center

Denver, CO 80225 


\section{CONTENTS}

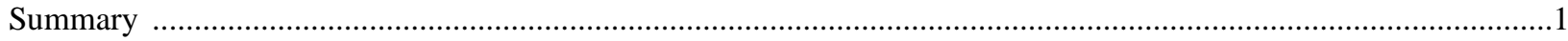

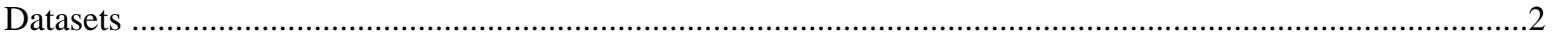

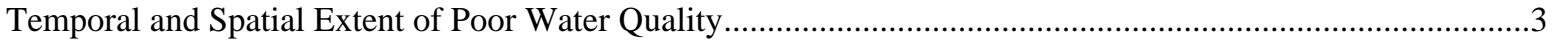

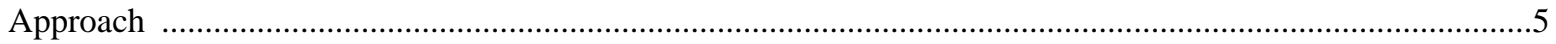

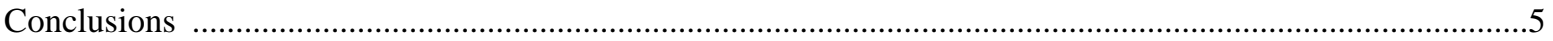

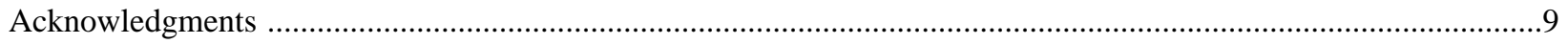

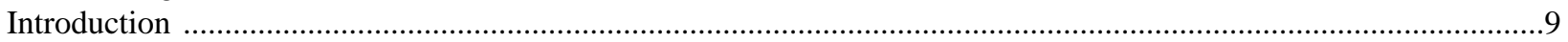

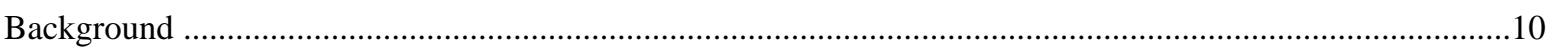

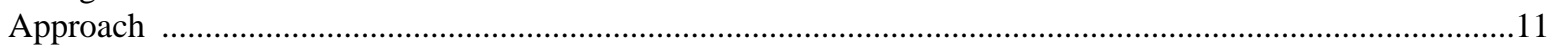

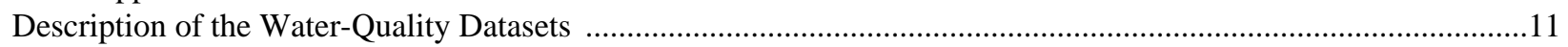

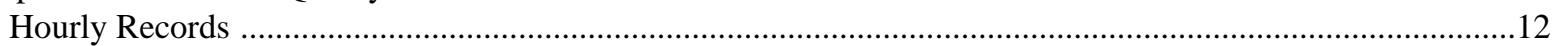

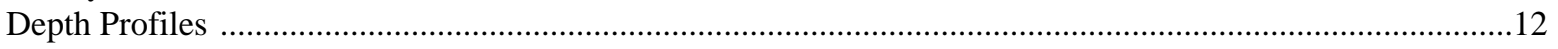

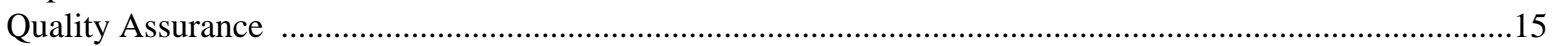

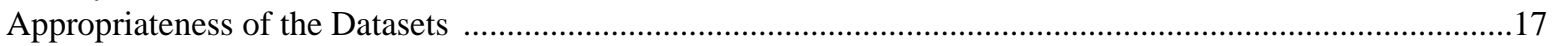

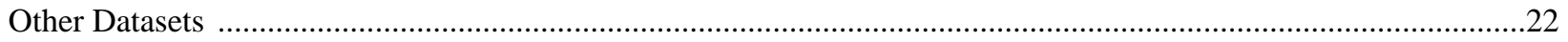

Description of the Temporal and Spatial Variability of Poor Water-Quality Conditions ......................................22

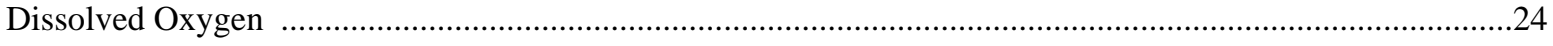

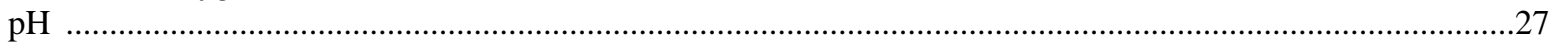

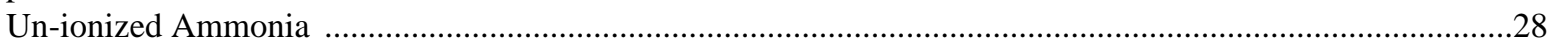

Hypotheses Relating Selected Water-Quality Variables to Lake Level ...............................................................31

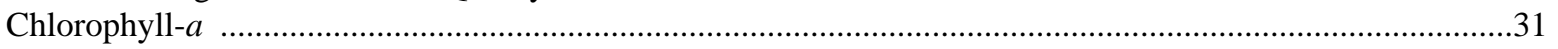

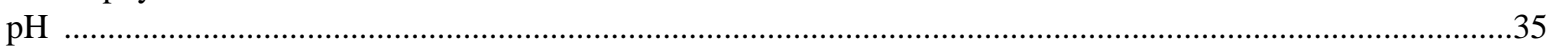

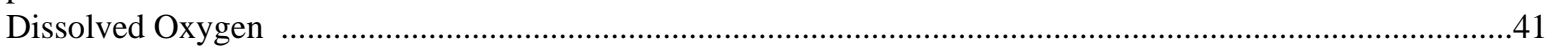

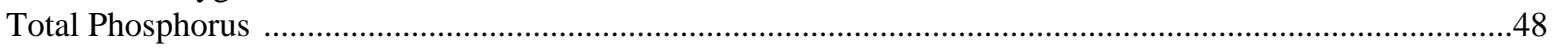

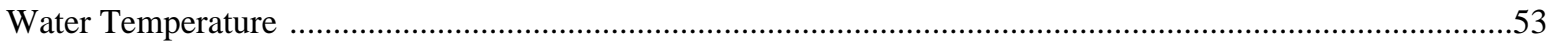

Hypotheses Relating Water Quality to Climatic Variables .............................................................................54

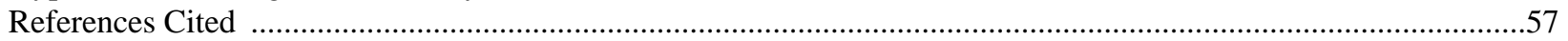




\section{FIGURES}

S1. Comparison of May through August end-of-month lake elevation for 1990-94 with the frequency distribution of the historical, post-dam end-of-month values for 1922-94, Upper Klamath Lake, Oregon.

1. Map showing Upper Klamath and Agency Lakes, Oregon, with sites where water-quality data were collected in 1990-94

2.- 3. Graphs showing:

2. Comparisons of depth-profile measurements with hourly measurements at 1-meter depth for dissolved oxygen, $\mathrm{pH}$, and water temperature, Upper Klamath Lake, Oregon, 1992-94 ... 15

3. Interagency comparisons of hourly and depth-profile dissolved oxygen concentration data at selected sites, Upper Klamath Lake, Oregon, July 1993.

4. Map showing June 25, 1995 synoptic survey data, including time of sample, surface $\mathrm{pH}$, surface dissolved oxygen concentration, and surface water temperature, Upper Klamath and Agency Lakes, Oregon

5.-33. Graphs showing:

5. Daily elevation of Upper Klamath Lake, Oregon, 1990-94.

6. Illustration of discrete and linear functions as represented by a random sample of 100 data points

7. Depth-profile dissolved oxygen data for Eagle Ridge, Shoalwater Bay, Wocas Bay, and Agency Lake (South), Upper Klamath and Agency Lakes, Oregon, June-September 1990-94

8. Depth-profile pH data for Eagle Ridge, Shoalwater Bay, Wocas Bay, and Agency Lake (South), Upper Klamath and Agency Lakes, Oregon, June-September 1990-94 .....

9. Frequency distributions of total ammonia and un-ionized ammonia concentrations for $\mathrm{pH}$ values greater than 9, Upper Klamath and Agency Lakes, Oregon, 1990-94

10. Comparison of May through August end-of-month lake elevation for 1990-94 with the frequency distribution of the historical, post-dam end-of-month values for 1922-94, Upper Klamath Lake, Oregon

11. Chlorophyll- $a$ concentration at selected sites, Upper Klamath and Agency Lakes, Oregon, May-October 1990-1994.

12. Relation of lake elevation on May 1 to the number of days from April 1 to the sampling date on which the algal bloom was first detected, Upper Klamath Lake, Oregon, 1990-94.... 33

13. Frequency distributions of lakewide chlorophyll- $a$ data, by month, Upper Klamath and Agency Lakes, Oregon, June-September 1990-94

14. Relation of chlorophyll- $a$ concentration to lake elevation, Upper Klamath and Agency Lakes, Oregon, June 1990-94.

15. Relation of daily maximum $\mathrm{pH}$ from hourly records at Ball Bay, Shoalwater Bay, and Midnorth to lake elevation, Upper Klamath Lake, Oregon, June-September, 1992-94 ...........36

16. Depth-profile pH data at Shoalwater Bay, Upper Klamath Lake, Oregon, May-October 1990-94 6

17. Depth-profile pH data at Midnorth, Upper Klamath Lake, Oregon, May-October 1990-94 ..38

18. Frequency distributions of lakewide depth-profile $\mathrm{pH}$ data, by month, Upper Klamath

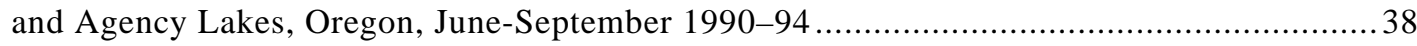

19. Relation of maximum $\mathrm{pH}$ from depth-profile data at selected sites to lake elevation, Upper Klamath and Agency Lakes, Oregon, June 1990-94....

20. Relation of daily minimum dissolved oxygen concentration from hourly records to lake elevation, Upper Klamath Lake, Oregon, June-September 1992-94

21. Depth-profile dissolved oxygen data at Shoalwater Bay, Upper Klamath Lake, Oregon, May-October 1990-94

22. Depth-profile dissolved oxygen data at Midnorth, Upper Klamath Lake, Oregon, May-October 1990-94

23. Frequency distributions of lakewide depth-profile dissolved oxygen data, by month, Upper Klamath and Agency Lakes, Oregon, June-September, 1990-94 
24. Relation of minimum dissolved oxygen concentration from depth-profile data at selected sites to lake elevation, Upper Klamath and Agency Lakes, Oregon, July 1990-94 …............47

25. Total phosphorus concentration at selected sites, Upper Klamath Lake, Oregon, May-October 1990-94

26. Frequency distributions of lakewide total phosphorus concentration data, Upper Klamath and Agency Lakes, Oregon, May through October, 1990-94.

27. Relation of lakewide median chlorophyll- $a$ concentration to lakewide median total phosphorus concentration, Upper Klamath and Agency Lakes, Oregon, June 1990-94..........50

28. Relation of total phosphorus concentration to lake elevation, Upper Klamath and

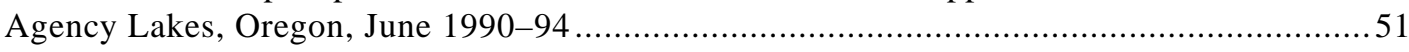

29. Frequency distribution of daily average wind speed recorded at Klamath Falls airport,

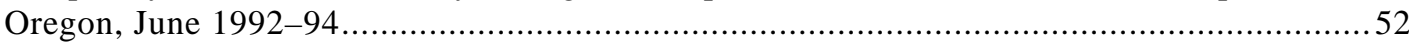

30. Lakewide median of depth-profile water temperature data, Upper Klamath and Agency Lakes, Oregon, May-October 1990-94

31. Daily average water temperature from hourly records at Midnorth and Shoalwater Bay superimposed on the average of the daily maximum and minimum air temperatures recorded at Klamath Falls airport, Upper Klamath Lake, Oregon, April-October, 1992-94 ...55

32. Relation of number of days from April 1 to the sampling date on which the algal bloom was first detected to the number of degree-days from April 1 to May 15, Upper Klamath Lake, Oregon, 1990-94. 56

33. Relation of median June chlorophyll- $a$ concentration to the number of degree-days from April 1 to May 15, Upper Klamath and Agency Lakes, Oregon, 1990-94

\section{TABLES}

S1. Cumulative degree-days from April 1 to May 15, Upper Klamath and Agency Lakes, Oregon.

1. Number of days for which dissolved oxygen and $\mathrm{pH}$ data are available from hourly record sites, Upper Klamath Lake, Oregon, June-September 1992-94

2. Number of sampling dates at depth-profile sites, Upper Klamath and Agency Lakes, Oregon, June-September 1990-94

3. Water-quality data excluded or qualified as a result of quality-assurance screening of Hydrolab data from Upper Klamath and Agency Lakes, Oregon, May-October 1992-94.

4. Number of sampling days at hourly record sites, grouped by the number of hours that dissolved oxygen concentration was less than 4 milligrams per liter during the day, Upper Klamath Lake, Oregon, June-September 1992-94

5. Percentage of dissolved oxygen concentrations in the depth-profile dataset less than 4 milligrams per liter, Upper Klamath and Agency Lakes, Oregon, June-October 1990-94

6. Number and location of dissolved oxygen concentrations less than 4 milligrams per liter in the depth-profile dataset, Upper Klamath and Agency Lakes, Oregon, June-October 1990-94

7. Number of sampling days at hourly record sites, grouped by the number of hours that $\mathrm{pH}$ was greater than 9.5 during the day, Upper Klamath Lake, Oregon, June-September 1992-94 .....

8. Percentage of $\mathrm{pH}$ values in the depth-profile dataset greater than 9.5, Upper Klamath and Agency Lakes, Oregon, June-October 1990-94.

9. Number and location of $\mathrm{pH}$ values in the depth-profile dataset greater than 9.5, Upper Klamath and Agency Lakes, Oregon, June-October 1990-94.

10. Number of un-ionized ammonia concentrations exceeding the chronic 4-day average guideline by year and site, Upper Klamath Lake, Oregon, 1990-94

11. Frequency of June pH values greater than 9.5, Upper Klamath Lake, Oregon, 1990-94

12. Frequency summary of July dissolved oxygen values less than 4 milligrams per liter, Upper Klamath Lake, Oregon, 1990-94 
CONVERSION FACTORS

\begin{tabular}{lcc}
\hline \multicolumn{1}{c}{ Multiply } & By & To obtain \\
\hline foot $(\mathrm{ft})$ & LENGTH & meter $(\mathrm{m})$ \\
& AREA & \\
& 2.590 & square kilometer $\left(\mathrm{km}^{2}\right)$ \\
square mile $\left(\mathrm{mi}^{2}\right)$ & CONCENTRATION, IN WATER & parts per million $(\mathrm{ppm})$ \\
& 1 & parts per billion $(\mathrm{ppb})$
\end{tabular}

Temperature in degrees Celsius $\left({ }^{\circ} \mathrm{C}\right)$ as follows:

$$
{ }^{\circ} \mathrm{C}=\left({ }^{\circ} \mathrm{F}-32\right) / 1.8 \text {. }
$$

Sea level: In this report "sea level" refers to the National Geodetic Vertical Datum of 1929 (NGVD of 1929)—a geodetic datum derived from a general adjustment of the first-order level nets of both the United States and Canada, called Mean Sea Level of 1929. 


\title{
Relation Between Selected Water-Quality Constituents and Lake Stage in Upper Klamath and Agency Lakes, Oregon
}

\author{
By Tamara M. Wood, Gregory J. Fuhrer, and Jennifer L. Morace
}

\section{SUMMARY}

Upper Klamath Lake is a large (140 square-mile), shallow (mean depth about $8 \mathrm{ft}$ ) lake in south-central Oregon that the historical record indicates has been eutrophic since its discovery by non-Native Americans. In recent decades, however, the lake has had annual occurrences of near-monoculture blooms of the blue-green alga Aphanizomenon flos-aquae. In 1988 two sucker species endemic to the lake, the Lost River sucker (Deltistes luxatus) and the shortnose sucker (Chasmistes brevirostris), were listed as endangered by the U.S. Fish and Wildlife Service, and it has been proposed that the poor water quality conditions associated with extremely long and productive blooms are contributing to the decline of those species.

It has also been proposed that the low lake levels made possible by the construction of a dam at the outlet from the lake in 1921 have contributed to worsening water quality through a variety of possible mechanisms (Jacob Kann, Klamath Tribes, written commun., 1995). One such mechanism would be an increase in internal phosphorus loading from resuspended sediments (Jacoby and others, 1982), resulting from an increase in bottom shear stresses at lower lake levels (Laenen and LeTourneau, 1996), leading in turn to more intense algal blooms. Another possible mechanism is an earlier triggering of algal blooms. When early spring lake levels are low, greater light intensity at the sediment surface might speed recruitment of algal cells from the sediments. Sediment recruitment has been shown to be an important contributor to water column biomass increases in A. flos aquae (Barbiero and Kann, 1994) and Gloeotrichia echinulata (Barbiero, 1993). An earlier bloom could result in poor water quality conditions occurring earlier in the year, when young-ofthe-year fish may be more susceptible to those conditions.

Lake level can also influence water quality directly. An increased frequency of sediment resuspension at lower lake levels could increase chemical and biological oxygen demand, resulting in decreased dissolved oxygen concentrations. Sediment oxygen demand also may be enhanced at lower lake levels because it is concentrated over a smaller volume of water. Some compensation for increased oxygen demand at lower lake levels might be provided by increased reaeration, if the water column mixes from top to bottom more frequently.

Based on the analysis of data that they have been collecting for several years, the Klamath Tribes recently recommended that the Bureau of Reclamation (Reclamation) modify the operating plan for the dam to make 
the minimum lake levels for the June-August period more closely resemble pre-dam conditions (Jacob Kann, written commun., 1995). The U.S. Geological Survey (USGS) was asked to analyze the available data for the lake and to assess whether the evidence exists to conclude that year-to-year differences in certain lake water-quality variables are related to year-toyear differences in lake level. The results of the analysis will be used as scientific input in the process of developing an operating plan for the Link River Dam.

\section{Datasets}

Two water-quality datasets were analyzed. The first was a series of hourly records of $\mathrm{pH}$, dissolved oxygen, and water temperature, each of approximately a week's duration. The records were collected at 3 sites over 3 years, 1992 through 1994, with enough consistency to define the seasonal patterns. This dataset provided information about the diel extremes in dissolved oxygen and $\mathrm{pH}$ and the seasonal pattern in the diel cycle, but measurements were limited to a depth of $1 \mathrm{~m}(3.28 \mathrm{ft})$.

The second dataset was a set of depth profiles of $\mathrm{pH}$ and dissolved oxygen and concurrent depth-integrated samples for nutrients and chlorophyll- $a$. The profiles were collected at approximately biweekly intervals at nine sites (seven in Upper Klamath and two in Agency Lake) over the 5 years 1990 through 1994. These depth profiles provided information on the depth-dependence of dissolved oxygen and $\mathrm{pH}$, and allowed more extensive year-to-year comparisons than did the hourly records. Because measurements were made at each site only once during the sampling day, however, they did not capture the daily extremes in water quality.

Lake level is measured daily by the USGS at three sites around the lake: Rocky Point, Rattlesnake Point, and near the city of Klamath Falls. These daily measurements are then used to compute a spatially weighted average of the lake level that is reported in the USGS annual
Water-Data Report for Oregon. The average lake levels were used in this report.

Two climatic datasets were used in this report; both were collected at the Klamath Falls airport. Air temperature was recorded as a daily maximum and daily minimum value. Cloud cover was quantized on a daily basis into one of seven levels.

Because the focus of this study was primarily to examine possible relations between water quality and lake level, the lake level data provide an important context for the discussions that follow (fig. S1). The order of ranking

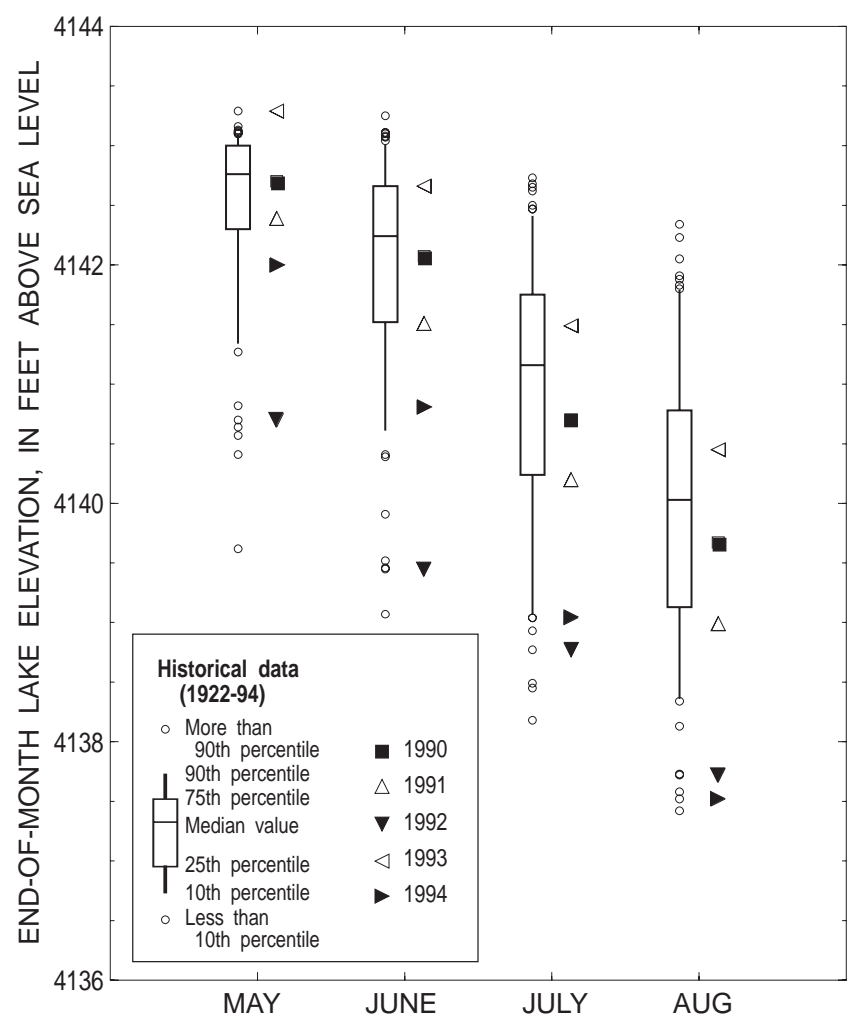

Figure S1. Comparison of May through August end-of-month lake elevation for 1990-94 with the frequency distribution of the historical, post-dam end-of-month values for 1922-94, Upper Klamath Lake, Oregon.

of the years 1990 through 1994 by lake level remains consistent through the summer-from low to high, the years rank as 1992, 1994, 1991, 1990, and 1993 - with the exception that 1992 and 1994 reverse order in August. The relative difference between each of the years is 
not fixed, however. For example, the difference between the highest-level year, 1993, and the lowest-level year, 1992, was about $3.2 \mathrm{ft}$ at the end of June, and about $2.7 \mathrm{ft}$ at the end of July. At the end of June, the 1994 elevation was nearly $1.5 \mathrm{ft}$ higher than the 1992 elevation, but by the end of July of those two years, the elevations were very similar.

Relations between water quality and lake level were the primary focus of this study. Important perspective, however, is provided by other datasets that demonstrate some correlation with lake level and underscore the fact that apparent relations with lake level are not necessarily causal. For example, 1992 was not only the lowest-lake-level year, it was also the year characterized by the warmest spring temperatures (table S1) and the most cloud-free days. The years 1990 and 1994 were very similar in terms of degree-days, and characterized by a lower number than 1992; 1993 had the second-lowest number, and 1991 the lowest.

Table S1. Cumulative degree-days from April 1 to May 15, Upper Klamath and Agency Lakes, Oregon.

\begin{tabular}{ccccc}
\hline $\mathbf{1 9 9 0}$ & $\mathbf{1 9 9 1}$ & $\mathbf{1 9 9 2}$ & $\mathbf{1 9 9 3}$ & $\mathbf{1 9 9 4}$ \\
\hline 486 & 330 & 572 & 388 & 477 \\
\hline
\end{tabular}

\section{Temporal and Spatial Extent of Poor Water Quality}

Criteria for poor water quality were selected in order to calculate exceedances, and to make possible succinct descriptions of where and when poor water-quality conditions occur. These criteria were based on acute-toxicity bioassays that were applicable to larval and juvenile Klamath Lake suckers, but did not address the issue of chronic toxicity. The $\mathrm{pH}$ criterion was slightly lower and the dissolved oxygen criterion slightly higher than the acute-toxicity bioassays suggested, in an attempt to account for chronic effects. They were, therefore, somewhat subjective. The criteria used were dissolved oxygen concentrations less than $4 \mathrm{mg} / \mathrm{L}$ and $\mathrm{pH}$ values greater than 9.5. The choice of these two values is not intended to suggest an equivalence in their deleterious effects on fish. For example, even brief periods of very low dissolved oxygen could be lethal to fish, especially at high summer temperatures, whereas fish could be expected to endure longer periods of very high $\mathrm{pH}$ and survive. It should also be recognized that the choice of any single value to distinguish between poor and acceptable water quality can be deceptive, because gradation is lost (for example, $3.9 \mathrm{mg} / \mathrm{L}$ is deemed poor water quality using the $4 \mathrm{mg} / \mathrm{L}$ criterion, and 4.1 $\mathrm{mg} / \mathrm{L}$ is deemed acceptable, even though the difference between the two is only $0.2 \mathrm{mg} / \mathrm{L}$ ).

A 1986 U.S. Environmental Protection Agency (EPA) guideline that related ammonia toxicity to $\mathrm{pH}$ and total ammonia concentration yielded few exceedances of the guideline over the range in $\mathrm{pH}$ values to which the guideline applied. Nearly $40 \%$ of the data could not be evaluated with respect to that guideline, however, because the values fell outside of the range in $\mathrm{pH}$ to which the guideline applied. Concentrations of un-ionized ammonia were generally far below experimentally derived $\mathrm{LC}_{50} \mathrm{~s}$ (the concentration that causes the death of one-half of a population exposed to it within a given period of time).

The hourly records provided a good description of the diel cycle at 1-m depth. At this depth, when $\mathrm{pH}$ values greater than 9.5 were recorded, they often persisted through a large part of the sampling day, whereas dissolved oxygen values less than $4 \mathrm{mg} / \mathrm{L}$ were more typically an excursion of short duration (a few hours).

In the depth-profile dataset, occurrences of high $\mathrm{pH}$ (defined as $\mathrm{pH}$ greater than 9.5) were more common than occurrences of low dissolved oxygen (defined as concentration less than $4 \mathrm{mg} / \mathrm{L}$ ). This was due primarily to the spatial distribution of these extremes, both 
around the lake and with depth. Low dissolved oxygen concentration was often measured at only one or two sites on a sampling date (most often at Eagle Ridge and Shoalwater Bay), and was typically restricted to near-bottom measurements. In contrast, on the sampling days when high $\mathrm{pH}$ was measured, it was often measured at most of the sites around the lake and typically extended throughout the water column.

The depth-profile dataset provided important information about the seasonality and spatial variability of high $\mathrm{pH}$ and very low dissolved oxygen, and their relation to algal blooms. Water quality in Upper Klamath and Agency Lakes, in particular dissolved oxygen concentration and $\mathrm{pH}$, is affected by algal growth. Water quality conditions during the first part of the growing season-May and June-were determined by whether the first bloom of $A$. flos aquae started early, rose rapidly, and peaked at a high value. When those conditions occurred, June $\mathrm{pH}$ frequently exceeded 9.5. The first bloom always began by early July, therefore the frequency of July $\mathrm{pH}$ exceeding 9.5 was generally high.

$\mathrm{pH}$ conditions during the latter part of the growing season-August and Septemberwere defined by whether algal growth was sustained through this period. In years that algal growth was sustained (1990 and 1991), pH values remained high. In 1992, 1993, and 1994, algal growth was not sustained through the end of the season. As a result, $\mathrm{pH}$ values fell to lower levels after July.

The following statements summarize the seasonality of high $\mathrm{pH}$ values in the depth-profile dataset:

- 1990, 1992, and 1994 were characterized by earlier algal blooms than 1991 and 1993. Consequently, June $\mathrm{pH}$ during 1990 , 1992, and 1994 often exceeded 9.5 (45\% of values in 1990, 65\% of values in 1992 and $68 \%$ of values in 1994). June $\mathrm{pH}$ during 1991 and 1993 exceeded 9.5 less frequently (no exceedances in 1991 and $17 \%$ of values in 1993).

- July chlorophyll- $a$ values were similar in all 5 years of data, and were indicative of hypertrophic conditions (median values approximately $100 \mu \mathrm{g} / \mathrm{L}$ ). Consequently, July $\mathrm{pH}$ frequently exceeded 9.5 in all years except 1992 (41\%, 57\%, 4.5\%, 58\%, and $66 \%$ of values in 1990, 1991, 1992, 1993, and 1994, respectively). July chlorophyll- $a$ concentrations in 1992 had decreased substantially from June, despite values around $100 \mu \mathrm{g} / \mathrm{L}$.

- Late blooms in 1990 and 1991 caused September $\mathrm{pH}$ during those years to frequently exceed 9.5 (37\% and $68 \%$ of values in 1990 and 1991, respectively); therefore, high $\mathrm{pH}$ is not strictly an early season problem.

Dissolved oxygen concentrations less than $4 \mathrm{mg} / \mathrm{L}$ did not occur in any of the 5 years considered until after the first bloom of the season began to decline. In 1992 the first bloom expanded rapidly and peaked in June, and the first low dissolved oxygen concentrations, a few values close to $0 \mathrm{mg} / \mathrm{L}$, were measured in July. The first bloom started somewhat later in 1990 and 1994, and dissolved oxygen concentrations less than $4 \mathrm{mg} / \mathrm{L}$ were first measured in July, although the lowest concentrations were not as low as the lowest concentrations measured in 1992. In 1991 and 1993, the first bloom started later and did not peak until July, and the lowest dissolved oxygen concentrations of the season were delayed until September in 1993 and October in 1991.

The following statements summarize the seasonality of low dissolved oxygen concentrations in the depth profile dataset:

- June dissolved oxygen concentrations were greater than $6 \mathrm{mg} / \mathrm{L}$ in all 5 years of data.

- In July, low dissolved oxygen (less than 4 $\mathrm{mg} / \mathrm{L}$ ) was measured in 3 of the 5 years from 1990 to $1994(12 \%, 12 \%$, and $8 \%$ in 1990, 1992, and 1994, respectively). 
- In August, low dissolved oxygen was measured in all years, but at a lower frequency in $1991(14 \%, 1 \%, 21 \%, 17 \%$, and $22 \%$ in 1990 through 1994 , respectively).

- In September, low dissolved oxygen was measured in all years except 1994, but at a greater frequency in 1990 and 1993 than in 1991 and $1992(12 \%, 4 \%, 4 \%$, and $22 \%$, in 1990 through 1993, respectively).

- In October, low dissolved oxygen was measured in 1991 and 1993 (13\% and 3\%, respectively).

Upper Klamath and Agency Lakes were hypertrophic in all years of the analysis, a condition that is associated with poor living conditions for many organisms. Hypertrophic conditions include very high $\mathrm{pH}$ and very low dissolved oxygen concentration. The timing of those poor living conditions could be interpreted in large part in the context of the timing of heavy algal blooms that occurred at some point in every year of the analysis.

Hypertrophic conditions could be associated with other poor living conditions that were not investigated in this report. For example, A. flos-aquae has been shown to produce toxins that could be detrimental to larval or adult fish, but there is no direct evidence of such toxicity in Upper Klamath Lake.

\section{Approach}

This review was formulated as a series of hypotheses relating water quality constituents to lake level (or, in two cases, to a climatic variable). Each hypothesis was explicitly stated, and then the relevant data were examined to determine if they were consistent with that hypothesis. The hypotheses were intended to provide a context for discussion, but were not formal hypotheses in the statistical sense and were not stated in the null format. Detailed analyses of the raw data and their distributions were relied on to provide evidence that was either consistent or not consis- tent with the hypothesis. Formal statistical analyses were inappropriate, given the few years of data that were available and the difficulty in removing intra-annual variability when comparing data from year to year.

The purpose of this study was to establish whether there is an apparent relation between certain water-quality variables and lake level. The existence of an apparent relation by itself, however, does not prove causality; in order for causality to be established, a specific mechanism would have to be proposed and tested. Therefore, it was not the purpose of this study to establish a cause-andeffect relation between water quality and lake level.

There is an additional limitation inherent in using a 5-year data record to examine interannual variability. In the cases that the data did not support a relation between water quality and lake level, the lack of support is not proof that there is no such relation. Because ecological systems are highly complex, there may be subtle but important relations that cannot be discerned with only 5 years of data.

\section{Conclusions}

There was no evidence for a relation between any of the water-quality variables considered (chlorophyll- $a$, dissolved oxygen, $\mathrm{pH}$, and total phosphorus) and lake level on the basis of the seasonal (May-October) distribution of the data or a summary seasonal statistic. This was predictable, based on the fact that no year considered in this analysis had consistently good water-quality conditions. Dissolved oxygen concentrations low enough, and $\mathrm{pH}$ values high enough, to be harmful to fish were measured at some point in each year; high phosphorus concentrations were measured at some point in each year, and in each year there was a heavy bloom of A. flos aquae. Discussions of the relation between water quality and lake level, therefore, focussed on June and July. A focus on the shorter time 
period was warranted because events set in motion during June could affect water quality through the rest of the season, and because certain life stages of young-of-the-year fish may be more susceptible to poor conditions in June and July than in later months.

June was an important month to examine chlorophyll- $a, \mathrm{pH}$, and total phosphorus because the first bloom of the year usually started in late May, June, or early July. In June it was found that the concentration of chlorophyll- $a$ and the frequency of very high $\mathrm{pH}$ values were lower at higher lake levels, and that the start of the first bloom was delayed at higher lake levels. Stated in the hypothesis format:

Year-to-year differences in June chlorophyll-a concentrations are related to year-to- year differences in June lake level, such that June chlorophyll-a concentration is lower at higher lake levels.

Year-to-year differences in the timing of the first bloom are related to year-to-year differences in June lake level, such that the first bloom is delayed at higher lake levels.

Year-to-year differences in the June frequency of $\mathrm{pH}$ values greater than 9.5 are related to year-to-year differences in June lake level, such that the frequency is lower at higher lake level.

Two hypotheses relating the timing of the first bloom and June chlorophyll- $a$ concentration to the number of degree-days from April 1 to May 15 (a measure of the relative warmth of the spring) were also tested and were found to be supported by the data. Specifically, the first bloom started later and June chlorophyll- $a$ concentrations were lower when spring temperatures were cooler and the number of cloudy days was greater:

Year-to-year differences in the timing of the first bloom are related to year-to-year differences in the number of degree-days between April 1 and May 15, such that the bloom occurs earlier at a higher number of degree-days.

Year-to-year differences in June chlorophyll-a concentration are related to year-to-year differences in the number of degree-days between April 1 and May 15, such that concentrations are higher at a higher number of degree-days.

To the extent that lake level and climatic variables are correlated there is no way to separate their relative effects on water quality. Lake level and climatic variables may act concurrently or in conjunction with each other to affect water quality, or one of them may be a real causal factor while the other is not.

The total phosphorus and dissolved oxygen data were inconclusive regarding any relation between those variables and lake level. In the case of phosphorus, June 1992 concentrations in Upper Klamath Lake, and 1992 and 1994 concentrations in Agency Lake, were very high and undoubtedly contributed to particularly heavy blooms in those years. Based on well-established relations between wind magnitude and fetch, wave conditions, water depth, and bottom shear stresses, it would be reasonable to assume that low lake levels in 1992 resulted in increased resuspension of bed sediment and contributed to the high phosphorus loadings at that time. The data themselves, however, were not sufficient to sort out the relative importance of, for example, wind, high $\mathrm{pH}$, and lake level.

The results of an analysis of the frequency of dissolved oxygen concentrations less than $4 \mathrm{mg} / \mathrm{L}$ during July (a month that was important in terms of dissolved oxygen because very low concentrations were measured in some years but not in others) were inconclusive, in part because of the high degree of variability in this quantity and the inconsistency of sampling. The seasonal downward trend in dissolved oxygen appeared 
to be determined primarily by the algal growth cycle, probably to a lesser extent by temperature control of saturation, but not primarily by lake level. Nonetheless, the very high June chlorophyll- $a$ concentrations in 1992 were followed by July dissolved oxygen concentrations that were particularly low compared to those in July of other years (12\% of concentrations were less than $4 \mathrm{mg} / \mathrm{L}$, and a concentration near zero was measured at the surface at one site), and there are sound physically based reasons to assume that low lake level in that year could have played a role in creating those conditions. The extent to which oxygen demands that are enhanced by lower lake levels superimpose on other seasonal effects and influence the lower extremes of the dissolved oxygen distribution cannot be quantified with this dataset. This influence may be important when water quality in the lake is already marginal for aquatic life. In a situation where dissolved oxygen conditions are marginal for fish at a relatively high lake level, the possibility that, at a lower lake level, concentrations could be lowered only slightly but enough to threaten fish survival cannot be ruled out.

Selected details of the results of testing each of the hypotheses relating water quality to lake level and climatic variables are included below:

Chlorophyll-A: June chlorophyll- $a$ concentrations progressed somewhat systematically from high values to low values as June lake level increased. Chlorophyll- $a$ concentrations in June of 1992 (median value 248 $\mu \mathrm{g} / \mathrm{L})$, the year of lowest lake level, contrasted markedly with concentrations in June of 1993 (median value $65 \mu \mathrm{g} / \mathrm{L}$ ), the year of highest lake level. In June of 1994, when lake level was higher than in June of 1992, chlorophyll-a concentrations were between those of 1992 and 1993. Median concentrations in June of 1990, a year of higher lake level than 1994 and lower lake level than in 1993, were lower than in 1993, but 1990 was sparsely sampled in June. There was some indication that median June concentrations would have been higher had all sites been sampled, and that the 1990 bloom may have been similar to the 1994 bloom. One of the 5 years, 1991, had minimal algal growth in June and did not fit the pattern of increasing chlorophyll- $a$ with decreasing lake level shown by the other years.

Two hypotheses stated a relation between early season algal growth and climatic variables. There was an apparent relation between the timing of the first bloom and June chlorophyll- $a$ concentration and the number of degree days between April 1 and May 15. June chlorophyll- $a$ concentrations were highest in 1992 (median value $248 \mu \mathrm{g} / \mathrm{L}$ ), the year of highest degree-days, and contrasted markedly with the lowest June concentrations (median value $18 \mu \mathrm{g} / \mathrm{L}$ ), which were measured in 1991, the year of lowest degree-days. For that reason, the timing of the first bloom in 1991, a year that had an especially cold spring and little algal growth in June, was consistent with the relation between the timing of the first bloom and the degree-day variable, whereas it was not consistent with the relation between the timing of the first bloom and lake level. An analysis of cloud cover data yielded similar results, because heavier overall spring cloud cover was associated with cooler overall spring temperatures.

June concentrations were related in large part to the timing of the first bloom. The earlier the bloom started, the earlier chlorophyll- $a$ concentrations began to increase, with the result that June concentrations overall were higher when the bloom started earlier. There were, however, differences in peak bloom concentrations apart from the differences in timing. The year of lowest lake level and highest degree-days, 1992, had both the earliest and the heaviest bloom. The first bloom in the highest-lake-level year, 1993, and in the lowest-degree-day year, 1991, peaked at concentrations that were less than half of those in 1992. 
pH: Because of the relation between $\mathrm{pH}$ and algal growth, the dependence of $\mathrm{pH}$ on lake level and degree-days parallels to some extent the dependence of chlorophyll- $a$ on lake level and degree-days. An earlier bloom leads to an earlier rise in chlorophyll- $a$ in June and consequently an earlier rise in $\mathrm{pH}$. As a result, the earlier blooms in 1990, 1992 and 1994 were associated with higher June $\mathrm{pH}$ than the later blooms in 1991 and 1993. The highest June $\mathrm{pH}$ values were measured in 1994, even though the strength of the bloom (as indicated by chlorophyll- $a$ concentration) was less than in 1992. The frequency with which mid-June $\mathrm{pH}$ values exceeded 9.5 was $96 \%, 100 \%$, and $31 \%$ in 1992, 1994, and 1990, respectively. Very high $\mathrm{pH}$ values, therefore, accompanied the early blooms in 1990 and 1994, even though the blooms in those years were substantially lighter (as indicated by chlorophyll- $a$ concentration) than the 1992 bloom. There were no June exceedances in 1991, when there was minimal algal growth in June, or in 1993, when the bloom was the latest of all 5 years.

Very high $\mathrm{pH}$ values were measured in July in all 5 years of analysis, regardless of the timing of the first bloom. The hourly data at 1-m depth indicated that the difference in the timing of the first bloom between 1992 and 1993 resulted in a 3-week difference in the timing of the occurrence of the highest $\mathrm{pH}$ values; the difference in the timing of the first bloom between 1993 and 1994 resulted in a difference of about a week and a half in the timing of the occurrence of the highest $\mathrm{pH}$ values. Data have not been analyzed in this study to show how a shift of this magnitude in poor water-quality conditions may affect the endangered young-of-the-year suckers over their summertime life stage, but it could be important if June represents a particularly critical time in their life cycle.

Dissolved OXYGEN: The hourly records showed that the $1-\mathrm{m}$ diel minimum dissolved oxygen concentration had an overall downward trend from June through September. Because the 3 years for which hourly records were available had quite different dissolved oxygen concentrations at similar lake levels, it is most likely that the temporal trend was determined primarily, but not exclusively, by the algal growth cycle and water temperature control of saturation. A decline in lake level over the season could impose an additional seasonal pattern by concentrating the sediment oxygen demand over a smaller volume of water, or by increasing the frequency of wind-driven resuspension of oxygen- demanding material. The dissolved oxygen data analyzed in this report were not sufficient to quantify the relative contribution of these low-lake-level-enhanced oxygen demands. Neither were data available to quantify the effect of reaeration, which might also be enhanced at lower lake levels.

The relation between year-to-year differences in dissolved oxygen concentration and year-to-year differences in lake level was examined carefully in July, because very low concentrations were first measured in that month. Dissolved oxygen concentration was highly variable, and did not exhibit clear temporal progressions through July as did chlorophyll- $a$ and $\mathrm{pH}$ through June. The result of a frequency analysis of July data was as follows: $12 \%, 0 \%, 12 \%, 0 \%$, and $5 \%$ of dissolved oxygen concentration values were less than $4 \mathrm{mg} / \mathrm{L}$ in 1990 through 1994, respectively (Upper Klamath Lake only). These results were judged to be unreliable because variability in the data was high and the sampling was inconsistentthere were different numbers of sampling dates in each year and some sites were represented in some years but not in others.

There was, however, enough information to conclude that dissolved oxygen conditions were particularly poor during July 1992. Early in July, dissolved oxygen concentrations near zero were measured at the surface of the water column at one site; in other years conditions this severe were not measured until August or 
September. If June lake level or the number of degree days contributed to the very early, very heavy bloom in 1992, then they (one, the other, or both) probably contributed to the conditions that led to particularly poor water quality (as indicated by low dissolved oxygen concentrations) in July of that year. Low July lake level in that year may have made conditions worse by concentrating oxygen-demanding material into a smaller water column, or by increasing the frequency of mixing events that resuspended oxygen-demanding material.

There is no way with available data, however, to quantitatively assess the degree to which those oxygen demands, enhanced by low lake level, influenced the low extremes of the concentration distribution.

TOTAL PHOSPHORUS: There was no consistent relation between total phosphorus concentration and lake level during any month. In June, which was important in terms of the timing and magnitude of the first bloom, the lowest-lake-level year, 1992, was exceptional: phosphorus concentrations were much higher than in the other 4 years (in Agency Lake, June concentrations were higher in both 1992 and 1994). Because June total phosphorus concentration was correlated with June chlorophyll- $a$, high concentrations of phosphorus probably contributed to exceptionally heavy blooms in 1992 (Upper Klamath and Agency Lakes) and 1994 (Agency Lake only). Low lake level, in a synergistic combination with other environmental variables such as high winds during May and June of 1992, may have contributed to the high phosphorus concentrations by way of enhanced internal loading.

It was noteworthy, however, that phosphorus concentration only increased through the season (as lake level dropped) during 1990 and 1991, with the result that, in August and September, Upper Klamath Lake concentrations were lowest in both the lowest-lake-level years (1992 and 1994) and the highestlake-level year (1993). This was curious because theoretical bottom stress calculations indicate that resuspension of bottom sediments would increase dramatically at the lower lake levels of August and September, compared to June and July (Laenen and LeTourneau, 1996). Clearly, a critical set of circumstances is required to initiate internal loading of phosphorus; lake level is only one of those circumstances, and its relative importance is unknown. The phosphorus dataset analyzed in this study was not sufficient to quantify the contributions of wind magnitude, fetch, high $\mathrm{pH}$, and lake level (four of the most easily identified relevant variables), to the internal loading of phosphorus.

\section{ACKNOWLEDGMENTS}

The authors gratefully acknowledge the aid and advice provided by Dennis Cooke (Kent State University, Kent, Ohio).

Special thanks to (1) Jacob Kann (the Klamath Tribes) for providing water-quality data collected on the Upper Klamath and Agency Lakes and the wind-speed data recorded at the Klamath Falls airport, (2) Mark Buettner and Michael Berg (both of the Bureau of Reclamation) for coordinating and providing the water-quality data collected by various entities on the Upper Klamath and Agency Lakes, (3) Sharon Campbell (National Biological Service) for providing the data recorded at the weather station on Agency Lake, (4) George Taylor (Oregon Climate Service) for providing climate data recorded at the Klamath Falls Airport, (5) Natural Resource Scientists, Inc. for providing cloud cover data recorded at the

Klamath Falls Airport, (6) Bernadine Bonn (U.S. Geological Survey) for developing the Monte Carlo simulations, and (7) Howard Harrison and Bruce Fisher (both of the U.S. Geological Survey) for their help in developing a GIS database of lake bathymetry.

\section{INTRODUCTION}

Upper Klamath Lake is a large (140 square-mile), shallow (mean depth about $8 \mathrm{ft}$ ) lake in south-central Oregon that the historical record indicates has been eutrophic since its discovery by 
non-Native Americans (Bortleson and Fretwell, 1993). In recent decades, however, the lake has had annual occurrences of near-monocultural blooms of the blue-green alga Aphanizomenon flos-aquae. In 1988 two sucker species endemic to the lake, the Lost River sucker (Deltistes luxatus) and the shortnose sucker (Chasmistes brevirostris), were listed as endangered by the U.S. Fish and Wildlife Service, and it has been proposed that the poor water quality conditions associated with extremely long and productive blooms are contributing to the decline of those species. It has also been proposed that the low lake levels that were made possible by the construction of a dam at the outlet from the lake in 1921 have contributed to worsening water quality through a variety of possible mechanisms (Jacob Kann, Klamath Tribes, written commun., 1995). During the construction of the dam, the rock sill that held back Upper Klamath Lake prior to that time was removed, so that regulated post-dam lake levels could be about $3 \mathrm{ft}$ lower than pre-dam conditions allowed. This difference in elevation amounts to nearly a halving of the depth over much of the lake, and it is reasonable to postulate that such large changes in lake volume could, indeed, affect lake water quality.

Based on the analysis of data that they have been collecting for several years, the Klamath Tribes recently recommended that the Bureau of Reclamation (Reclamation) modify the operating plan for the dam to make the minimum lake levels for the June-August period more closely resemble pre-dam conditions (Jacob Kann, Klamath Tribes, written commun., 1995). The U.S. Geological Survey (USGS) was asked to analyze all the available pertinent data for the lake and to assess whether there is evidence to conclude that maintaining the proposed minimum lake levels will, in fact, result in improved water quality in the lake and, therefore, a better chance of survival for the sucker species. The scope of the USGS study was specifically limited to investigating the relation between lake level and water quality, although it is recognized that lake level can affect the survival of the sucker species by other means-loss of near-shore refugia, for example. Habitat and land-use considerations, however, are beyond the scope of this report.

\section{Background}

Most temperate shallow lakes are naturally productive (Mortensen and others, 1994). Productivity increases as the lake becomes shallower from sediment loading and the accumulation of organic matter, as it receives external nutrient loading leading to enriched water and sediments, and (or) it is drawn down so that the entire water column is in frequent contact with the sediments. Akinetes (resting cells) that originate in these enriched sediments start massive blue-green algal blooms in the spring after light and temperature conditions become favorable for growth. These early algal blooms initiate a series of processes that can produce poor water quality throughout the summer.

The impact of algal blooms on water quality is directly related to algal biomass, which in turn is often controlled by the concentration of phosphorus in the water column. When little or no water flows into the lake, internal phosphorus loading dominates, and the rate of this loading can be accelerated by the algae themselves. Intense photosynthesis drives up $\mathrm{pH}$, which can promote phosphorus desorption from iron hydroxides in sediments (Welch and others, 1988).

Most shallow lakes are polymictic. Brief periods of calm, warm weather, however, can allow thermal stratification to occur. Sediment oxygen demand is high in productive, warm, shallow lakes and an anoxic layer quickly develops over the sediments, stimulating phosphorus solubilization from iron complexes. Subsequent re-mixing produces additional increases in concentrations of phosphorus in the water column. In many shallow lakes that do not have much summer inflow algal bloom intensity throughout the summer can be limited by internal phosphorus loading.

High algal biomass coupled with brief, calm, nighttime conditions can lead to widespread low dissolved oxygen concentration throughout the water column. Respiratory demands of algae and the lake's sediment microbial community can exceed reaeration from the atmosphere, producing dissolved oxygen concentrations in the $1-3 \mathrm{mg} / \mathrm{L}$ range and conditions for phosphorus release over large areas of the lake. 
High $\mathrm{pH}$ and low dissolved oxygen concentrations can have negative impacts in aquatic communities beyond the roles of those conditions in internal phosphorus loading and algal blooms. Low dissolved oxygen and extremes of $\mathrm{pH}$ have lethal and (or) chronic sublethal effects upon many forms of aquatic life, including fish.

\section{Approach}

The approach taken in this report is to state a hypothesis relating a water quality variable to lake level, and then to examine the data to determine if they are consistent with that hypothesis. The hypotheses are intended to provide a context for discussion, but they are not formal hypotheses in the statistical sense and are not stated in the null format. Detailed analyses of the of the raw data and their distributions are relied on to provide evidence that is either consistent or not consistent with the hypothesis. Formal statistical analyses were inappropriate, given the few years of data that were available and the difficulty in removing intra-annual variability when comparing data from year to year.

The hypotheses are purposely stated broadly in order to allow latitude in exploration of the data. The direction of the relation between lake level and a water-quality variable is stated, because this study was motivated by the proposition that water quality can be degraded at lower lake elevations, but the specific form of the relation-linear, bimodal, and so forth-is not. The interpretation of the data should not be influenced by a preconception of the form the relation will take. For example, a bimodal relation suggests that the water-quality variable has one distribution below a certain lake level and another above that lake level, but the lake level that divides the two distributions should emerge from patterns in the data and not be a result of a preconceived grouping.

The primary focus of this study was to establish the existence or nonexistence of an evident relation between certain water-quality variables and lake level. For that reason, consideration of hypotheses that pose a relation between lake level and chlorophyll- $a, \mathrm{pH}$, dissolved oxygen, and phosphorus concentration make up the bulk of the analyses presented. The existence of an evident relation in itself does not imply causality; in order for causality to be established, a specific mechanism must be proposed and tested.

Possible mechanisms include, for example, an enhancement of internal phosphorus loading from resuspended sediments (Jacoby and others, 1982) due to increased bottom stresses for the same wind speed at lower lake levels (Laenen and LeTourneau, 1996), which in turn leads to more intense algal blooms. Another possible mechanism is an earlier triggering of algal blooms. When early spring lake levels are low, greater light intensity at the sediment surface might speed recruitment from the sediments. Sediment recruitment has been shown to be an important contributor to water column biomass increases in A. flos aquae (Barbiero and Kann, 1994) and Gloeotrichia echinulata (Barbiero, 1993). The data used in this study, however, were not collected with the intention of defining any of the physical, biological, or chemical mechanisms that could result in relations between water quality and lake level; therefore, those data may not be sufficient to establish causality.

Two hypotheses relating water quality to climatic variables are discussed near the end of this report. These hypotheses were examined in order to determine whether a different independent variable, one that is also related to water quality through recognized mechanisms, explains as much or more of the variability in the water quality dependent variable as does lake level. To the extent that lake level is itself correlated with climatic variables, a dependence on lake level cannot be distinguished from a dependence on, for example, air temperature and insolation. In that case, lake level and climatic variables might each explain part of the variability in water quality.

\section{DESCRIPTION OF THE WATER-QUALITY DATASETS}

Two water-quality datasets were used in the analyses that follow. Both resulted from a combined effort of Reclamation and the Klamath Tribes. These datasets resulted from different sampling strategies and, therefore, captured different features of the lake's water quality and lend themselves to differing types of analyses. The first dataset consists of hourly records of approximately 
a week's duration recorded at moored instruments suspended at a depth of $1 \mathrm{~m}$ from the surface, and is particularly suited to describing the diel cycle in $\mathrm{pH}$, dissolved oxygen and water temperature. The second dataset consists of depth profiles at several sites that were visited with some regularity over a 5-year period and is suited to describing seasonal and year-to-year variability.

\section{Hourly Records}

Beginning in July of 1992, records of approximately a week's duration were available from moored instruments that were placed at one or more of five sampling sites in the northern part of the lake: Pelican Bay, Pelican Bay Lab, Ball Bay, Shoalwater Bay and Midnorth (fig. 1). These sites were selected because they represent a range of habitats used by adult suckers. Measurements were recorded primarily on an hourly basis, therefore this dataset is referred to as "hourly" records. Some of the data, however, were recorded with a different frequency1992 and 1993 data at Midnorth were sampled halfhourly, and July/August 1992 data at Pelican Bay, Pelican Bay Lab and Ball Bay were sampled every 2 hours. The instruments were placed at 1-m depth and, therefore, recorded conditions representative of the middle part of the water column, which is least affected by near-surface and near-bottom conditions. In very shallow conditions, the 1-m placement could put the instrument closer to the bottom than the surface, but because the lake is shallow and usually well-mixed, conditions are often nearly uniform throughout the water column. None of the hourly records include data that were obviously representative of near-bottom conditions and therefore not comparable with the rest of the data.
The two exceptions to the 1-m depth placement were 1992 and 1993 data at Midnorth; instruments in those years at that site were placed at a mid-water-column depth rather than the 1-m depth used in 1994 at Midnorth and in all years at the other sites. Depths at Midnorth usually start out in June at between 2.5 and $3.5 \mathrm{~m}(4 \mathrm{~m}$ in a very high-lake-level year) and end up in September at between 2.5 and $1.5 \mathrm{~m}$, so that under the shallowest of conditions the mid-water-column location places the instrument nearer the surface and further from the bottom than the 1-m location. Because dissolved oxygen concentration sometimes varies over a large part of the water column, lateseason monitoring in 1992 and 1993 could potentially have systematically recorded higher dissolved oxygen concentration than in 1994, but there is no evidence that this happened.

The data coverage at any site during any given month was sporadic (table 1), but because these records often span several days at a time at 1-hour intervals, they are well-suited to describing the extremes in $\mathrm{pH}$, dissolved oxygen, and temperature that occur over the diel cycle. Two of the sites at which instruments were placed (Pelican Bay and the Pelican Bay Lab) were not considered in this analysis because conditions at those locations are influenced by the freshwater inflow to Pelican Bay and are not considered representative of the lake itself.

\section{Depth Profiles}

The Klamath Tribes began a sampling program in 1987 that involved taking depth profiles of $\mathrm{pH}$, dissolved oxygen concentration, and temperature, as well as nutrient and chlorophyll- $a$ sam-

Table 1. Number of days for which dissolved oxygen and $\mathrm{pH}$ data are available from hourly record sites, Upper Klamath Lake, Oregon, June-September 1992-94

[The values are for dissolved oxygen / pH data; BB, Ball Bay; MN, Midnorth; SB, Shoalwater Bay]

\begin{tabular}{|c|c|c|c|c|c|c|c|c|c|c|c|c|}
\hline \multirow{2}{*}{ Site } & \multicolumn{4}{|c|}{1992} & \multicolumn{4}{|c|}{1993} & \multicolumn{4}{|c|}{1994} \\
\hline & June & July & Aug & Sept & June & July & Aug & Sept & June & July & Aug & Sept \\
\hline BB & $0 / 0$ & $0 / 0$ & $6 / 6$ & $12 / 12$ & $21 / 22$ & $1 / 15$ & $12 / 31$ & $7 / 30$ & $28 / 29$ & $20 / 20$ & $6 / 6$ & $12 / 12$ \\
\hline $\mathrm{MN}$ & $15 / 15$ & $8 / 16$ & $19 / 19$ & $9 / 9$ & $13 / 13$ & $26 / 31$ & $12 / 15$ & $27 / 27$ & $8 / 15$ & $12 / 9$ & $14 / 14$ & $25 / 25$ \\
\hline $\mathrm{SB}$ & $0 / 0$ & $0 / 0$ & $6 / 6$ & $18 / 18$ & $13 / 15$ & $25 / 28$ & $10 / 24$ & $30 / 30$ & $22 / 22$ & $16 / 16$ & $25 / 25$ & $6 / 6$ \\
\hline
\end{tabular}




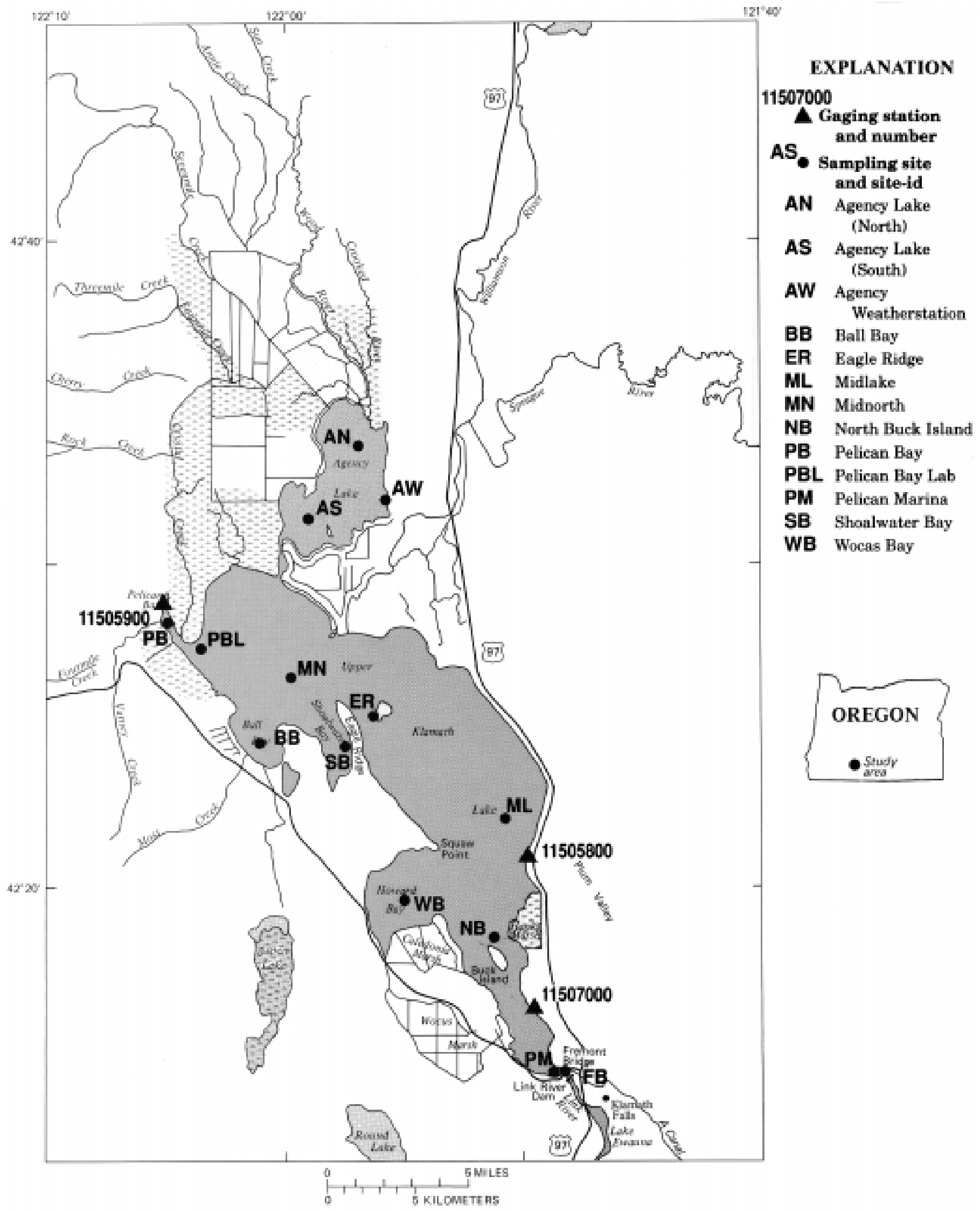

Figure 1. Upper Klamath and Agency Lakes, Oregon, with sites where water-quality data were collected in 1990-94. 
ples, at several sites around Upper Klamath and Agency Lakes (fig. 1) on a regular basis. Prior to 1990, sampling was infrequent (approximately monthly). Also prior to 1990, sampling for nutrients and chlorophyll- $a$ was done using a grab sampler, but starting in 1990 depth-integrated samples were taken. The change in sampling technique provided another reason, in addition to the sporadic sampling, to remove 1987, 1988, and 1989 from year-to-year comparisons.

Nine sites were sampled on a regular basis: North Buck Island, Wocas Bay, Eagle Ridge, Midlake, Midnorth, Pelican Marina, Shoalwater Bay, Agency Lake (South), and Agency Lake (North). During 1990, sampling was done by the Tribes on a nearly weekly basis, and from 1991 to 1994 on approximately a biweekly basis. Starting in 1992, the Tribes' data were supplemented with Hydrolab data collected by Reclamation at some of the same sampling sites. As a result, some stations were more frequently sampled than the rest during the latter part of 1992 and during 1993 and 1994 (table 2). The depth profiles generally consisted of a surface measurement and subsequent measurements at 1-m intervals, with the final measurement being $10 \mathrm{~cm}$ off the bottom. Reclamation sometimes took additional measurements at $0.5 \mathrm{~m}$ from the surface.

Temporal and spatial unevenness in the collection of the profile data can affect the interannual comparisons of the data. In this report, distributions of the data are accompanied by plots that show the individual data points making up the distribution, so that when unevenness in sampling may be important, it is apparent and is discussed.

Temporal unevenness in the data is important when the data are compared on a monthly basis. Because conditions could have changed significantly over that time period, uneven sampling over the month could have disproportionately weighted conditions that represented only a part of that month. Temporal unevenness was generally not an issue in 1990 and 1991, but late in 1992, Reclamation began supplementing the data gathered by the Tribes and the result was sometimes many more sampling dates during a month than there had been before. To assess the effect of this aspect of uneven sampling on the distribution of the data, Shoalwater Bay was picked as a test site and the seasonal distribution of the dissolved oxygen data was computed using all the data, biweekly means of all the data, and the first sample in each biweekly time period. The differences that each case produced in the seasonal distribution for each year were not great. However, the interannual variability in some water-quality variables (for example, dissolved oxygen) is small compared to intraseasonal variability, and interannual comparisons of the extremes in the distributions in that case are affected by uneven sampling. Where appropriate, the implications for the analyses are discussed.

Spatial unevenness appears in the data when a site is not represented by the same proportion of the total data points from year to year. As an example, Midlake was sampled less frequently than

Table 2. Number of sampling dates at depth-profile sites, Upper Klamath and Agency Lakes, Oregon, June-September 1990-94

[AN, Agency Lake (North); AS, Agency Lake (South); ER, Eagle Ridge; ML, Midlake; MN, Midnorth; NB, North Buck Island; PM, Pelican Marina; SB, Shoalwater Bay; WB, Wocas Bay]

\begin{tabular}{|c|c|c|c|c|c|c|c|c|c|c|c|c|c|c|c|c|c|c|c|c|}
\hline \multirow{2}{*}{ Site } & \multicolumn{4}{|c|}{1990} & \multicolumn{4}{|c|}{1991} & \multicolumn{4}{|c|}{1992} & \multicolumn{4}{|c|}{1993} & \multicolumn{4}{|c|}{1994} \\
\hline & June & July & Aug & Sept & June & July & Aug & Sept & June & July & Aug & Sept & June & July & Aug & Sept & June & July & Aug & Sept \\
\hline $\mathrm{AN}$ & 0 & 0 & 0 & 0 & 2 & 2 & 3 & 2 & 2 & 3 & 2 & 1 & 3 & 3 & 2 & 2 & 2 & 1 & 2 & 1 \\
\hline AS & 3 & 5 & 3 & 3 & 2 & 2 & 3 & 2 & 2 & 3 & 2 & 1 & 3 & 3 & 2 & 2 & 2 & 3 & 2 & 1 \\
\hline ER & 3 & 5 & 3 & 3 & 2 & 2 & 3 & 2 & 2 & 3 & 2 & 1 & 3 & 2 & 2 & 2 & 5 & 6 & 6 & 7 \\
\hline ML & 1 & 1 & 0 & 1 & 2 & 1 & 3 & 2 & 2 & 3 & 2 & 5 & 4 & 5 & 6 & 4 & 2 & 2 & 2 & 3 \\
\hline $\mathrm{MN}$ & 3 & 5 & 3 & 3 & 2 & 2 & 3 & 2 & 2 & 3 & 2 & 1 & 3 & 3 & 2 & 2 & 5 & 7 & 6 & 7 \\
\hline NB & 1 & 1 & 0 & 1 & 2 & 1 & 3 & 2 & 2 & 3 & 2 & 6 & 4 & 5 & 6 & 4 & 5 & 7 & 5 & 1 \\
\hline PM & 1 & 1 & 0 & 1 & 2 & 1 & 3 & 2 & 2 & 3 & 2 & 6 & 3 & 2 & 2 & 2 & 2 & 2 & 2 & 1 \\
\hline $\mathrm{SB}$ & 2 & 3 & 3 & 3 & 2 & 2 & 3 & 2 & 2 & 3 & 3 & 6 & 4 & 7 & 6 & 4 & 5 & 5 & 6 & 8 \\
\hline WB & 1 & 1 & 0 & 1 & 2 & 1 & 3 & 2 & 2 & 3 & 2 & 1 & 3 & 2 & 2 & 2 & 2 & 1 & 2 & 1 \\
\hline
\end{tabular}


Midnorth in 1990, about the same in 1991 and 1992, but more frequently in 1993. Again, when this is likely to be important it is discussed, and the accompanying graphics show individual data points so that the implications are clear.

\section{Quality Assurance}

Quality-assurance data were used to quantify the precision associated with nutrient determinations. Additionally, the precision associated with Hydrolab measurements of dissolved oxygen, $\mathrm{pH}$, and water temperature was assessed by making inter- and intra-agency comparisons of dissolved oxygen, $\mathrm{pH}$, and water temperature measurements taken from continuously deployed Hydrolabs and Hydrolabs used to make instantaneous vertical profiles of water quality.

Hydrolabs were independently deployed in Upper Klamath Lake by Reclamation and the Klamath Tribes to measure several parameters, including dissolved oxygen concentration, $\mathrm{pH}$, and water temperature. Additionally, depth-profile measurements of these parameters were made on a periodic basis to assess Hydrolab performance, describe vertical variations in water quality, and provide ancillary data for fish census surveys. To assess the precision associated with continuously deployed Hydrolabs, depth-profile Hydrolab measurements at $1 \mathrm{~m}$ were compared with hourly measurements.

Comparisons were made for dissolved oxygen, $\mathrm{pH}$, and water temperature at three sites that were sampled at a depth of $1 \mathrm{~m}$ from the water surface and that had depth-profile measurements at 1-m depth collected within 60 minutes of an hourly measurement (fig. 2). Hourly and profile measurements of dissolved oxygen concentration were generally within $\pm 2 \mathrm{mg} / \mathrm{L}$ of each other. However, hourly dissolved oxygen measurements tended to slightly exceed profile measurements (more data points are located below the 1:1 correspondence line than above it in fig. 2), which may indicate systematic differences in calibration between agencies or poor Hydrolab performance. Apart from a few anomalies, water temperatures measured by Reclamation and the Klamath Tribes were similar (most data points are located nearly on the $1: 1$ correspondence line in fig. 2), indicating a high degree of precision between agencies. Differences in $\mathrm{pH}$ values measured by Reclamation and the Klamath Tribes were
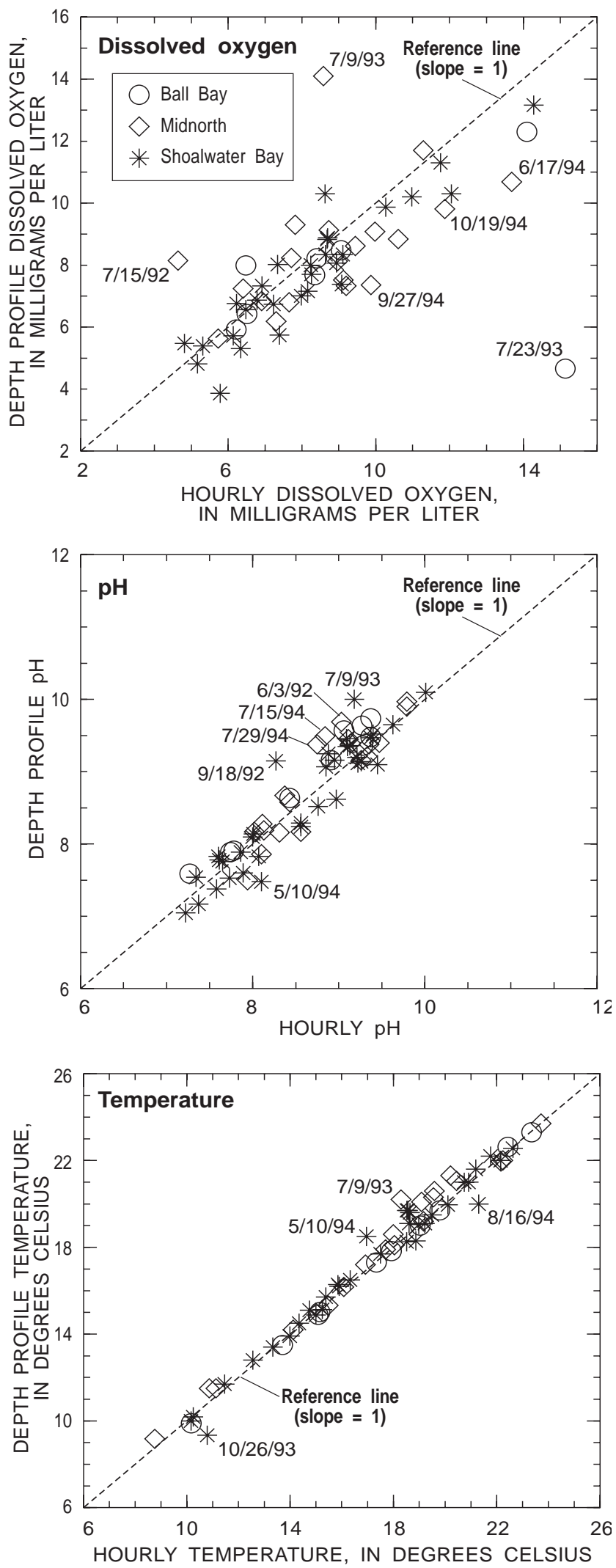

Figure 2. Comparisons of depth-profile measurements with hourly measurements at 1-meter depth for dissolved oxygen, $\mathrm{pH}$, and water temperature, Upper Klamath Lake, Oregon, 1992-94. All sites and all dates where there was a profile measurement within 1 hour of an hourly measurement from a moored instrument are included. 
within about $\pm 0.5 \mathrm{pH}$ units, and are not indicative of systematic interagency differences (data points are generally clustered around the 1:1 correspondence line in fig. 2); instead, they may be attributable to variations within the 60-minute comparison interval.

Hydrolab data were screened for anomalies by selecting a threshold value equal to the 90th percentile value of the absolute differences between hourly and profile measurements. Data that exceeded the threshold value were plotted in time series and overlaid with hourly data and profile data at $1 \mathrm{~m}$ from other sites to facilitate both intra- and interagency comparisons. Data with poor agreement were excluded or qualified (table 3 ). As an example, an hourly dissolved oxygen concentration (15.1 $\mathrm{mg} / \mathrm{L}$; July 23, 1993) at Ball Bay, which was three times the corresponding depth-profile measurement, was plotted along with hourly and depthprofile data from Shoalwater Bay and Midnorth (fig. 3). On the basis of interagency comparisons, Hydrolab records for the July 1993 deployment period at Ball Bay were judged inaccurate, and subsequently were excluded from analysis. In several cases, segments of hourly data were qualified

Table 3. Water-quality data excluded or qualified as a result of quality-assurance screening of Hydrolab data from Upper Klamath and Agency Lakes, Oregon, May-October 1992-94

[The 90th-percentile value of the absolute differences between hourly and depth-profile measurements at $1 \mathrm{~m}$ was selected as a threshold for screening Hydrolab measurements; the 90th percentile values for $\mathrm{pH}$, water temperature, and dissolved oxygen, respectively, were $\pm 0.6 \mathrm{pH}$ units, \pm 1.2 degrees Celsius, and \pm 2.0 milligrams per liter; when too few data were available to refute or substantiate questionable hourly and (or) depth-profile data, a record was retained but qualified; MN, Midnorth; SB, Shoalwater Bay; BB, Ball Bay]

\begin{tabular}{|c|c|c|c|}
\hline Site & Date & Comments & Action \\
\hline \multicolumn{4}{|c|}{ pH } \\
\hline $\mathrm{MN}$ & $06-03-92$ & Poor agreement between profile and hourly & Record retained, but qualified \\
\hline $\mathrm{MN}$ & $07-15-94$ & $\begin{array}{l}\text { Poor agreement between profile and hourly } \\
\text { at end of deployment }\end{array}$ & Excluded 07-12-1994 through 07-14-1994 \\
\hline $\mathrm{MN}$ & $07-29-94$ & Poor agreement between profile and hourly & Record retained, but qualified \\
\hline SB & $09-18-92$ & Poor agreement between profile and hourly & Record retained, but qualified \\
\hline SB & $07-09-93$ & Poor agreement between profile and hourly & Record retained, but qualified \\
\hline SB & $05-10-94$ & Poor agreement between profile and hourly & Record retained, but qualified \\
\hline \multicolumn{4}{|c|}{ Water temperature } \\
\hline $\mathrm{MN}$ & $07-09-93$ & Poor agreement between profile and hourly & Record retained, but qualified \\
\hline SB & $10-26-93$ & Poor agreement between profile and hourly & Record retained, but qualified \\
\hline SB & $05-10-94$ & Poor agreement between profile and hourly & Record retained, but qualified \\
\hline SB & 08-16-94 & Poor agreement between profile and hourly & Record retained, but qualified \\
\hline \multicolumn{4}{|c|}{ Dissolved oxygen } \\
\hline $\mathrm{BB}$ & $07-23-93$ & Questionable hourly values & Excluded 07-06-1993 through 07-23-1993 \\
\hline $\mathrm{BB}$ & $09-26-93$ & Questionable hourly values ${ }^{1}$ & Excluded 09-26-1993 through 09-30-1993 \\
\hline $\mathrm{MN}$ & $07-15-92$ & $\begin{array}{l}\text { Questionable hourly records and unacceptable } \\
\text { calibration at the end of deployment }\end{array}$ & Excluded 07-15-1992 through 07-22-1992 \\
\hline MN & $07-09-93$ & Poor agreement between profile and hourly & Record retained, but qualified \\
\hline $\mathrm{MN}$ & $06-17-94$ & Questionable hourly values & Excluded 06-11-1994 through 06-17-1994 \\
\hline MN & $09-27-94$ & Poor agreement between profile and hourly & Record retained, but qualified \\
\hline MN & $10-19-94$ & Poor agreement between profile and hourly & Record retained, but qualified \\
\hline
\end{tabular}




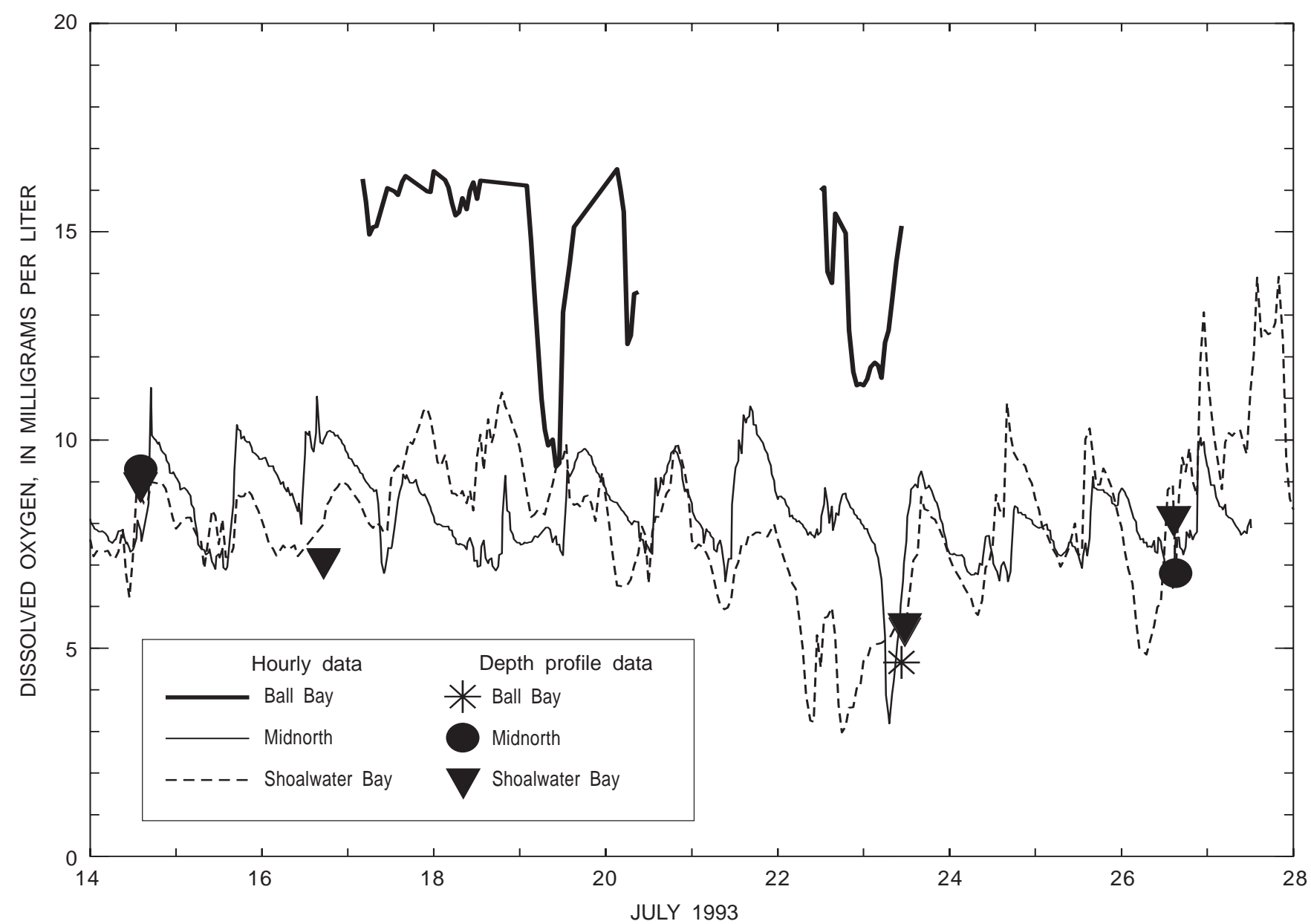

Figure 3. Interagency comparisons of hourly and depth-profile dissolved oxygen concentration data at selected sites, Upper Klamath Lake, Oregon, July 1993.

(poor agreement between 1-m profile data and hourly records) rather than excluded from analysis - a result of too few data to refute or substantiate erroneous hourly and (or) profile data.

Nutrient determinations were made by the Klamath Tribes' laboratory in 1990 (Jacob Kann, written communication, 1991) and, under a contract between the Klamath Tribes and Aquatic Research, Inc. from 1991 through 1994. The Klamath Tribes provided handwritten notes and thermal-print tape instrument readings of absorbance for nutrient determinations made at the Tribes' laboratory in 1990. The Klamath Tribes also provided 12 formal laboratory reports by Aquatic Research Inc. for nutrient determinations made on samples collected in 1993. The formal reports from Aquatic Research Inc. for 1993 were used to assess laboratory precision. During 1993, two blind duplicate samples generally were included within each sample batch-a sample batch represented samples collected over a period of 1 to 3 days. The relative differences (in percent) were calculated for duplicate determinations of ammonia, nitrite plus nitrate, soluble reactive phosphorus, total phosphorus, and total nitrogen. The range of the relative percent differences for ammonia ( 0.5 to $33 \%$ ), nitrite plus nitrate $(0.4$ to $40 \%)$, soluble reactive phosphorus ( 1 to $141 \%$ ), total phosphorus ( 2 to $93 \%)$, and total nitrogen (0.5 to $78 \%)$ spanned more than an order of magnitude. Although the ranges of the relative percent differences were large, the median relative percent differences for ammonia (7\%), nitrite plus nitrate $(7 \%)$, soluble reactive phosphorus (14\%), total phosphorus $(14 \%)$, and total nitrogen (12\%) were small and reflect an acceptable level of precision during the 1993 sampling period.

\section{Appropriateness of the Datasets}

This study specifically examined the relation between lake stage and interannual variations in various water-quality parameters, and therefore 
the temporal resolution of the datasets must be adequate to separate annual variability from year-to-year changes. The approximately biweekly sampling of the depth profiles was adequate to do that. One limitation encountered in the biweekly sampled data was that the resolution early in the season was not enough to precisely define the date of the first bloom.

In a lake experiencing a great deal of primary productivity, the highest extremes in $\mathrm{pH}$ usually occur in the late afternoon and the lowest extremes in dissolved oxygen concentration usually occur in the early morning. The time of day of the depth-profile sampling does not necessarily (in fact, most of the time it does not) capture either of those extremes. Fortunately, this analysis was able to draw upon two different data sets, and the hourly records provide information about the diel cycle at 1-m depth, although the temporal coverage in terms of total numbers of years is much less. In the depth profiles, however, the lowest dissolved oxygen values were often found at depth, and there is no information on how much of a diel cycle might be superimposed on the measured concentrations near the bottom. Nonetheless, in a lake as shallow as Upper Klamath Lake, a strong diel cycle at 1-m depth is probably still present to some extent at the 2 or $2.5 \mathrm{~m}$ depth of the bottom.

A large diel cycle also implies that there is no way to separate temporal and spatial variability on a given sampling date. Differences that appear to be spatial because of a change in value from one location of the lake to another can easily be temporal due to the time taken to travel between the two sites. Results of a quasi-synoptic survey done on June 25, 1995 demonstrate the range in temperature, $\mathrm{pH}$, and dissolved oxygen that can be expected when samples are taken around the lakes over a period of several hours (fig. 4). The range in values measured near the surface of Upper Klamath and Agency Lakes between about 10 a.m. and about 3 p.m. was about 5.2 to $18 \mathrm{mg} / \mathrm{L}$ dissolved oxygen, 8.5 to $10.4 \mathrm{pH}$ units, and 18 to $31^{\circ} \mathrm{C}-\mathrm{a}$ large variation around the lake in all three quantities. The map of the synoptic surveys shows that the variability around the lake has no particular spatial pattern (fig. 4). This amount of variability between sampling sites and sampling times on a single day may be acceptable if the goal is to track changes over the season and from year to year, but it would clearly dominate temporal changes in the lake on shorter (daily and weekly) time scales.

The sampling sites provided rather sparse coverage of the large surface of the lake, but they were distributed around the lake so as to capture any large-scale spatial trends in water quality (fig. 1). Missing, however, are data from shoreline sites that might be important in the life cycle of the sucker species.

The 5 years of data that are used in this report represent a large range in lake level, from a high lake level year (1993) to a low lake level year (1992) (fig. 5), but 5 years is still a short time over which to establish a year-to-year dependence of water quality on lake level, if one exists. The problem can be illustrated with the following examples, in which the dependent variable represents one of several possible water quality variables, and the independent variable represents lake level (fig. 6). A random number generator was used to generate 100 data points that represent a known, underlying function. A discrete case with two different means and a linear case were considered. In the discrete case, the two means were separated by 2 units of the dependent variable, and the linear case was derived as a best fit to the discrete case. In both cases the generated data were normally distributed around the underlying function, with a standard deviation of 1 unit of the dependent variable.

A Monte Carlo type of simulation was then carried out, in which five data points were selected such that 3 points represented random high-flow years and 2 points represented random low-flow years in each of 1000 trials. The dataset represented by the five data points was then tested for the null hypothesis $\mathrm{H}_{0}$ : All of the data have the same mean. In the discrete case, the null hypothesis was accepted 488 times and rejected 512 times ( $\alpha=0.05$ for a 1 -tailed test); in the continuous case, the null hypothesis was accepted 589 times and rejected 411 times $(\alpha=0.1)$.

In about one-half of the trials, five data points provided enough information to observe a significant relation between the dependent and independent variable. In both the discrete and the linear case, the standard deviation of the data around the underlying function was 1 unit, which was less than the total range in the underlying function (the total range in the discrete function was 


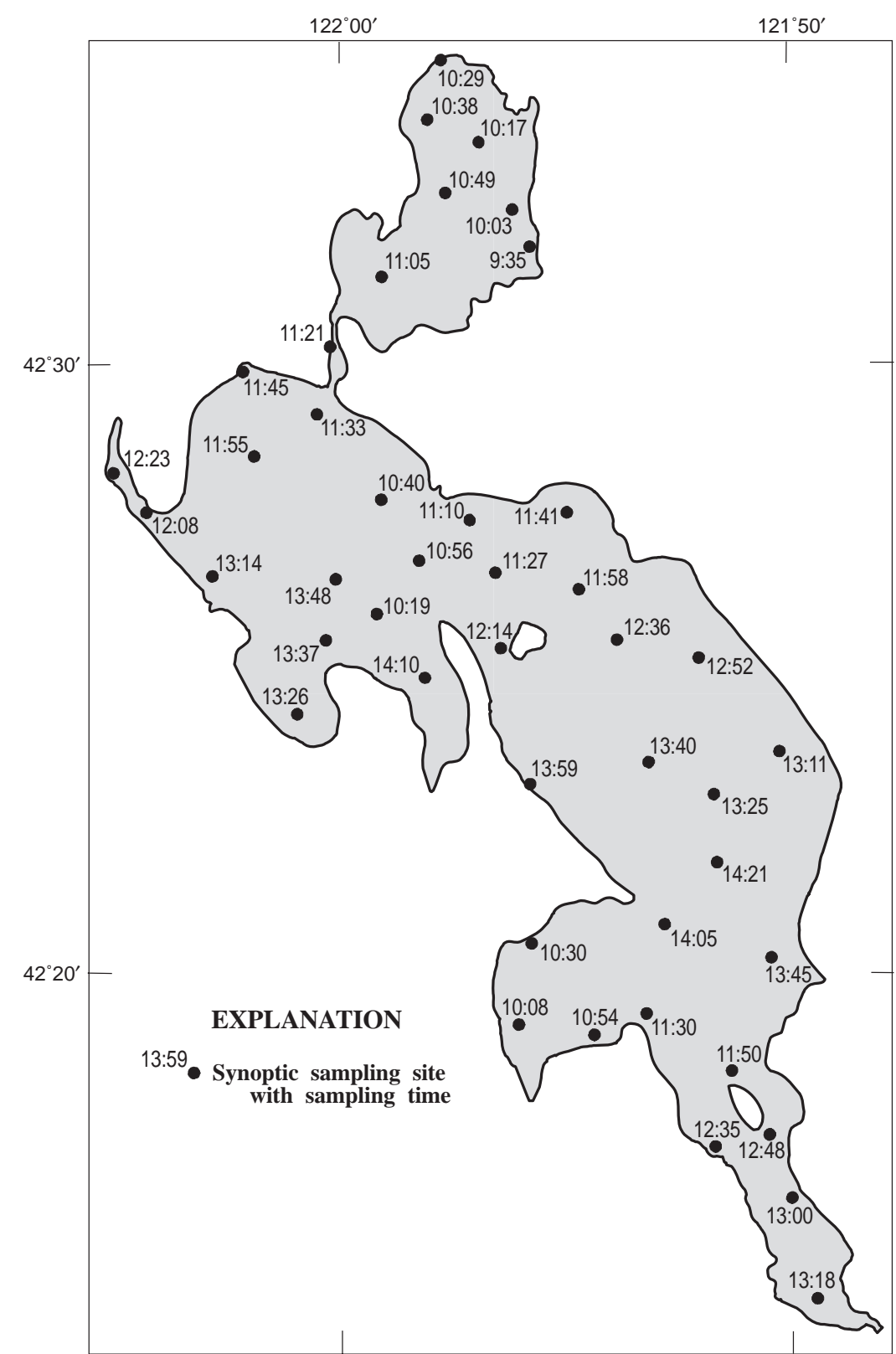

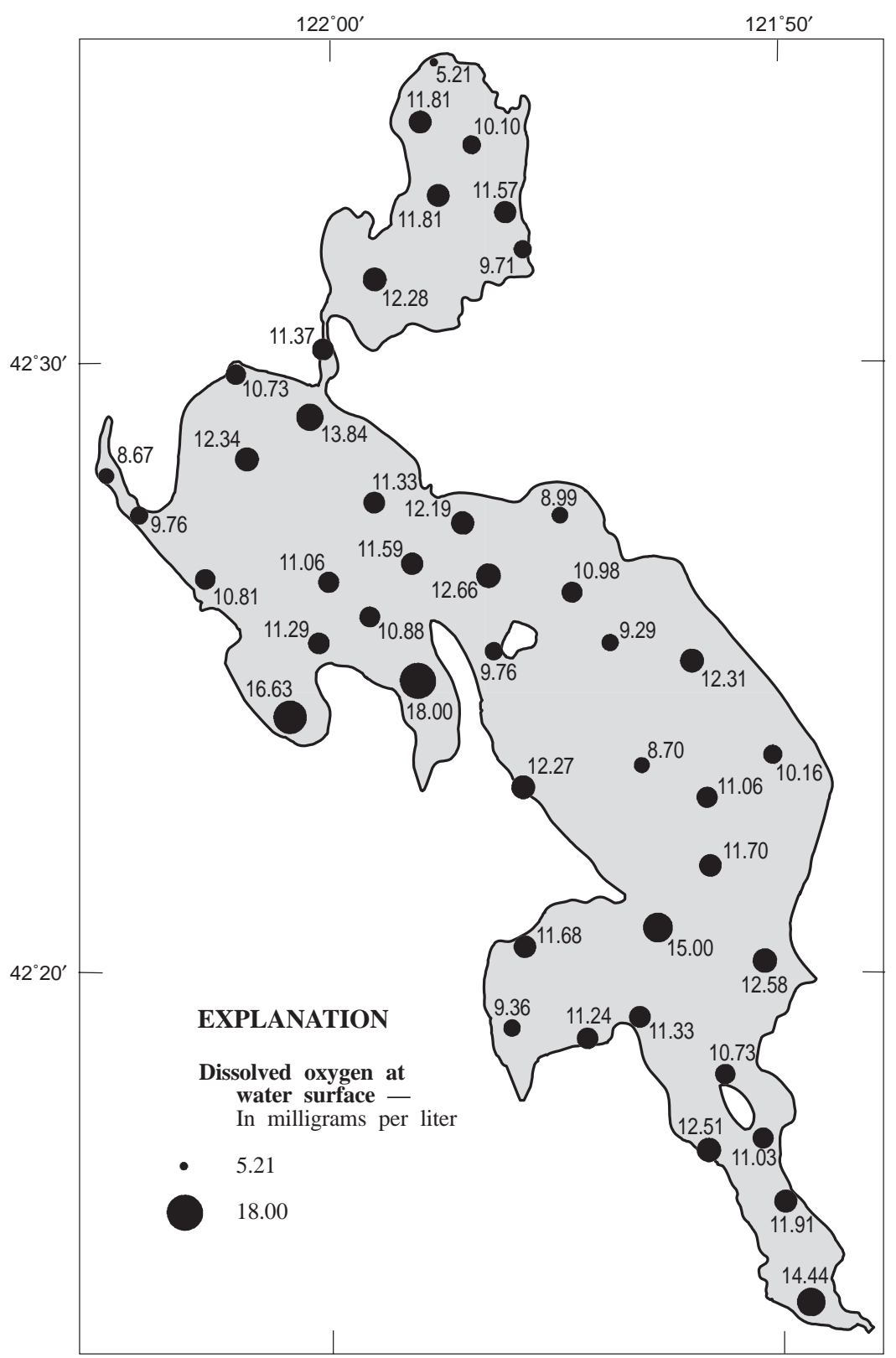

5 MILES

5 KILOMETERS

Figure 4. June 25, 1995 synoptic survey data, including time of sample, surface $\mathrm{pH}$, surface dissolved oxygen concentration, and surface water temperature, Upper Klamath and Agency Lakes, Oregon. (Source: Jacob Kann, The Klamath Tribes, written commun., 1995.) 

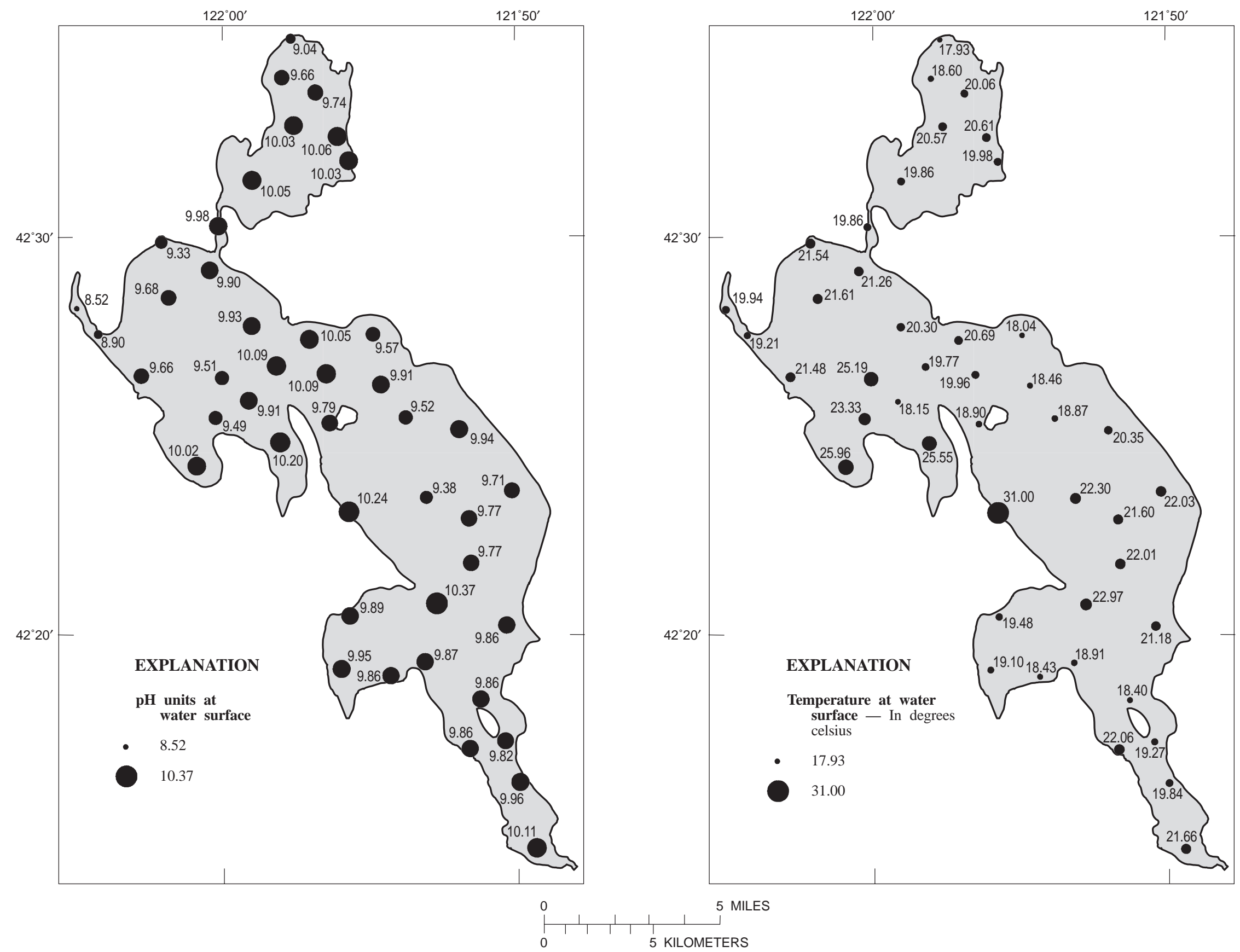

Figure 4. June 25, 1995 synoptic survey data, including time of sample, surface pH, surface dissolved oxygen concentration, and surface water temperature, Upper Klamath and Agency Lakes, Oregon. (Source: Jacob Kann, The Klamath Tribes, written commun., 1995.)—Continued. 


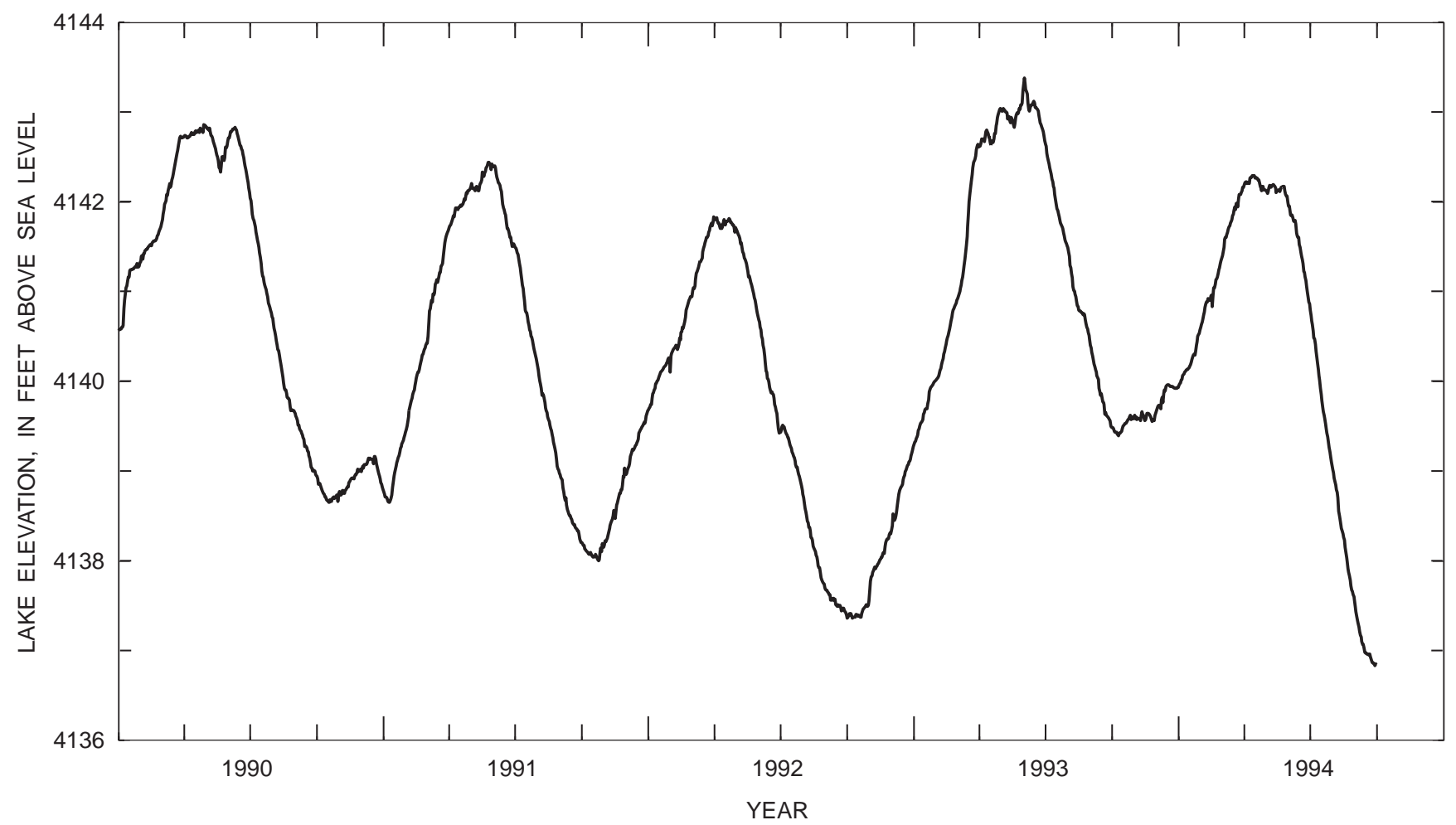

Figure 5. Daily elevation of Upper Klamath Lake, Oregon, 1990-94.

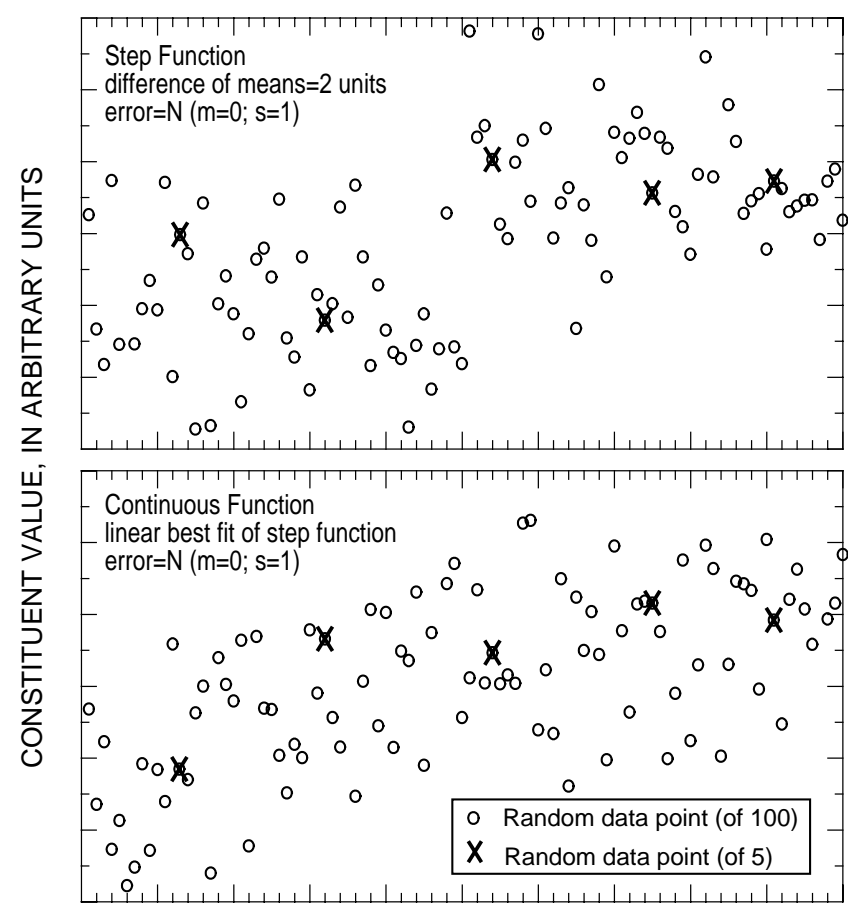

INCREASING LAKE ELEVATION, IN ARBITRARY UNITS

Figure 6. Discrete and linear functions as represented by a random sample of 100 data points. The data points are normally distributed around the underlying function in each case, with a standard deviation of 1 unit.
2 units; the total range in the linear function was slightly more than 2 units). Therefore, the variability in the dependent variable (water quality) that was explained by the independent variable (lake level) was greater than the variability that was not explained by the independent variable. Even under these conditions, about half of the time the underlying dependence on the independent variable (lake level) could not be established. As the standard deviation of the data increases compared to the range in the underlying function, it becomes even harder to establish a relation between the dependent and independent variable.

Applied to Upper Klamath and Agency Lakes, this difficulty means that horizontal, vertical, and temporal (on seasonal and shorter time scales) variability in 5 years of data can potentially obscure a real interannual dependence on lake level. When this occurs, it does not necessarily mean that there is no interannual relation between water quality and lake level; it means that 5 years of data is not enough to establish that there is a relation. Several decades of data might be required to firmly establish a dependence of water quality on lake level if the overall variability in water 
quality is large compared to the variability explained by lake level alone. Upper Klamath Lake is not unusual in not having such a long historical dataset to draw upon. It should also be recognized that there are many environmental influences on the lake, and 5 years of data do not capture all of their possible combinations and interactions. Because ecological systems are highly complex, there may be subtle but important relations that cannot be discerned with only 5 years of data.

\section{OTHER DATASETS}

Lake level is measured at half hour intervals at three gaged sites around the lake that are maintained by the USGS: Rocky Point, Rattlesnake Point and near the city of Klamath Falls. A daily average is calculated for each site. Those daily averages are then used to compute a weighted spatial average of the lake level that is reported in the USGS annual Water-Data Report. The spatial average lake level was used in this report.

Air temperatures were provided by the Oregon Climate Service and were recorded at the Klamath Falls airport. They were reported as daily maximum and minimum values. Wind speed data for 1992 through 1994 were provided by the Klamath Tribes and were also collected at the Klamath Falls airport. Cloud cover data recorded at the Klamath Falls airport were provided by Natural Resource Scientists, Inc.

\section{DESCRIPTION OF THE TEMPORAL AND SPATIAL VARIABILITY OF POOR WATER-QUALITY CONDITIONS}

Before analyzing the relation between water quality and lake level, it is useful to establish where and when poor water-quality conditions occur. In this discussion, poor water quality is defined as $\mathrm{pH}$ values or concentrations of dissolved oxygen or un-ionized ammonia that have the potential to be directly harmful to endangered sucker species. Criteria were chosen to define water conditions detrimental to certain sucker life stages, depending on site-specific conditions. The choices for $\mathrm{pH}$ and dissolved oxygen concentration were based primarily on acute toxicity tests, and a U.S. Environmental Protection Agency (USEPA) guideline was used for un-ionized ammonia. Acute-toxicity tests were done on larval and juvenile shortnose and Lost River suckers by Bellerud and Saiki (1995) and Monda and Saiki (1993, 1994). Based on the results of all three studies, Bellerud and Saiki (1995) concluded that early life stages of Lost River and shortnose suckers could experience high mortality if exposed to $\mathrm{pH}$ greater than or equal to 9.84 and dissolved oxygen concentration less than or equal to $2.3 \mathrm{mg} /$ $\mathrm{L}$. The authors note that the tests might underestimate the actual tolerance of the sucker species, since changes in water quality in their natural environment would occur more slowly than they did in the test environment. Nonetheless, the criteria used for $\mathrm{pH}$ and dissolved oxygen concentration in this report are somewhat more stringent than criteria based strictly on acute toxicity tests would be. This was an attempt to account for chronic effects in the absence of better information. It must be recognized, however, that the values are somewhat subjective.

The criterion for dissolved oxygen is a concentration less than $4 \mathrm{mg} / \mathrm{L}$, which comes from a composite of several studies. Bellerud and Saiki (1995) and Monda and Saiki (1993, 1994) found that dissolved oxygen concentrations below 2.3 $\mathrm{mg} / \mathrm{L}$ were toxic to age-group 0 (young-of-theyear) suckers. However, toxicity can occur at dissolved oxygen concentrations above those that are acutely lethal. Davis (1975) found $3.98 \mathrm{mg} / \mathrm{L}$ to be the dissolved oxygen concentration at which an "average" member of a mixed freshwater fish population exhibited signs of stress.

Juvenile and adult suckers have been found where the concentration of dissolved oxygen was less than $4 \mathrm{mg} / \mathrm{L}$, but fish surveys suggest that they may be less numerous under that condition, which may in turn indicate a low tolerance to that condition. During a 1988 beach seine survey, juvenile suckers were captured from shoreline locations with dissolved oxygen concentrations of $4.5 \mathrm{mg} / \mathrm{L}$ or greater (Buettner and Scoppettone, 1990), but no suckers were captured at several sites that had lower dissolved oxygen concentrations. Information gathered from regular (weekly or biweekly) tracking of adult Lost River and shortnose suckers during May-October 1993-95 (Mark Buettner, Bureau of Reclamation, unpub. data), showed that 
near-bottom dissolved oxygen concentrations associated with radio-tagged suckers in Upper Klamath Lake were mostly above $4 \mathrm{mg} / \mathrm{L}$ (90th percentile). During a trammel-netting survey throughout Upper Klamath Lake in September 1994, adult suckers were captured at the 18 sites with bottom dissolved oxygen concentration greater than or equal to $3.7 \mathrm{mg} / \mathrm{L}$; the two remaining net sites had bottom dissolved oxygen concentrations of $1.3 \mathrm{mg} / \mathrm{L}$, and no suckers were captured at those sites. During a spring 1994 survey Simon and others (1995) did not capture any juvenile suckers in Upper Klamath Lake where the dissolved oxygen concentration was less than $4 \mathrm{mg} / \mathrm{L}$; however, those sites represented a small fraction of the total number (4 out of 82 sites). During another spring survey in 1995, no sites where the dissolved oxygen concentration was less than $4 \mathrm{mg} / \mathrm{L}$ were visited, and larval suckers were captured at all sites (D.C. Simon, Oregon State University, unpub. data, 1995). Later in the same year, juvenile suckers were captured only at locations where the dissolved oxygen concentration was $6 \mathrm{mg} / \mathrm{L}$ and greater; a substantial number of sampling sites visited during that survey had dissolved oxygen concentration ranging from 0 to $6 \mathrm{mg} / \mathrm{L}$ (D.C. Simon, unpub. data, 1995).

The $\mathrm{pH}$ criterion is $\mathrm{pH}$ greater than 9.5 units, and derives primarily from bioassays done by Falter and Cech (1991) in which pH values greater than 9.55 were shown to cause a loss of equilibrium in juvenile suckers. Suckers in all life stages have been found in water with a $\mathrm{pH}$ of 9.5 or greater, but, as was the case for dissolved oxygen less than $4 \mathrm{mg} / \mathrm{L}$, the evidence from fish surveys suggests that they may be less numerous under that condition. Fewer numbers of suckers could be an indication that they have reduced tolerance to that condition. During the 1988 beach seine survey the highest $\mathrm{pH}$ where juvenile suckers were captured was 9.5 , even though several sites that were sampled had a pH greater than 9.5 (Buettner and Scoppettone, 1990). However, juvenile suckers were captured at shoreline locations where there was an instantaneous pH of 10 in 1995 (D.C. Simon, unpub. data, 1995). Earlier in the same year, larval suckers were captured only at sites where the $\mathrm{pH}$ was less than or equal to 9.7, and at that time several sites had $\mathrm{pH}$ greater than 9.7. Nineteen, sixteen, and thirty-three percent of bottom $\mathrm{pH}$ readings associated with radio-tagged sucker locations were 9.5 or greater in 1993, 1994, and 1995, respectively.

For ammonia, a USEPA guideline was used (U.S. Environmental Protection Agency, 1986; modified in a written commun. by Margarete Heber, USEPA, July 30, 1992), even though nearly one-third of the data were characterized by $\mathrm{pH}$ values that exceeded the upper limit of the range of applicability of the guideline ( $\mathrm{pH} 9$ ). Un-ionized ammonia concentrations were also compared to several experimentally determined $\mathrm{LC}_{50}$ values. Monda and Saiki (1993, 1994) and Bellerud and Saiki (1995) conducted un-ionized ammonia toxicity tests on hatchery-reared larval and juvenile Lost River and shortnose suckers. They measured un-ionized ammonia $\mathrm{LC}_{50}$ 's of 0.75 and $0.7 \mathrm{mg} / \mathrm{L}$ for juvenile Lost River suckers (with lower 95\% confidence intervals of 0.34 and $0.60 \mathrm{mg} / \mathrm{L}$ ) and 0.54 for larval Lost River suckers (lower $95 \%$ confidence interval of $0.43 \mathrm{mg} / \mathrm{L}$ ). Additionally, they measured $\mathrm{LC}_{50}$ 's ranging from 0.75 to $1.4 \mathrm{mg} / \mathrm{L}$ for larval shortnose suckers (lower 95\% confidence intervals were 0.73 and $1.38 \mathrm{mg} / \mathrm{L}$ ) and an $\mathrm{LC}_{50}$ of 0.956 and $0.34 \mathrm{mg} / \mathrm{L}$ for juvenile shortnose suckers (lower $95 \%$ confidence intervals were 0.14 and $0.32 \mathrm{mg} / \mathrm{L}$ ).

Toxins actively secreted or released at death by A. flos-aquae may be a factor in fish mortality. This potential factor, which could also be connected to water levels and water temperature, has not been investigated in Upper Klamath and Agency Lakes and should not be discounted until it is. Carmichael (1986) has described an alkaloid produced by A. flos-aquae that is a potent neurotoxin and contact irritant. This compound is toxic to fish, and it becomes more toxic as the cell population becomes denser and older, and as water temperature increases (Gentile and Maloney, 1969). Because the appearance of blue-green algal toxins is common in U.S. lakes (see, for example, Repavich and others, 1990), including western lakes (see, for example, Kann and Falter, 1987), it is possible that $A$. flos-aquae produces a toxin in Agency and Upper Klamath Lakes. Lower water levels, along with the early, high temperature of most shallow lakes and the long water residence times in the summer, could combine to concentrate an algal toxin. An investigation of the significance of this problem in Agency and Upper Klamath 
Lakes is encouraged, but is beyond the scope of this report.

The hourly and depth-profile datasets lend themselves to differing strategies of analysis. The hourly records are useful for analyzing the diel cycle to determine whether extreme water-quality conditions, when they occurred, tended to be an excursion lasting for a brief period during the day, or whether conditions detrimental to the fish were recorded through the entire diel cycle. The depth profiles do not yield information about diel extremes, but they do contain a more complete description of the water column. The depth profiles were obtained at more sites around the lake than were the hourly records, and 5 years of data were available for year-to-year comparisons (the hourly records cover only 3 years).

\section{Dissolved Oxygen}

The hourly records were analyzed for the number of hours in a day over which a dissolved oxygen concentration less than $4 \mathrm{mg} / \mathrm{L}$ was recorded. The results for June-September (table 4) demonstrate that (1) an excursion into low dissolved oxygen concentration was a relatively rare event, and that (2) these excursions, when they did occur, tended to be of short duration. Dissolved oxygen concentration less than $4 \mathrm{mg} / \mathrm{L}$ was recorded for more than 6 hours on 1 day in 1992, 4 days in 1993, and 2 days in 1994. The information in table 4 supports the conclusion-limited to a depth of $1 \mathrm{~m}$-that conditions of very low dissolved oxygen concentration generally do not last for more than a few hours. The depth-profile data (table 5) indicate that vertical variation in dissolved oxygen can occur and that conditions nearer the bottom can be quite different from those at $1 \mathrm{~m}$. An overall analysis of the profile data reveals that a large percentage of the data were recorded when the concentration was less than $4 \mathrm{mg} / \mathrm{L}$, especially during the latter part of the season, August and September. The Agency Lake stations were included in this analysis, but the percentages did not change substantially when the analysis was done without including those stations. Clearly a much larger percentage of the depth-profile dataset is made up of concentrations of dissolved oxygen less than $4 \mathrm{mg} / \mathrm{L}$. The differ-

Table 4. Number of sampling days at hourly record sites, grouped by the number of hours that dissolved oxygen concentration was less than 4 milligrams per liter during the day, Upper Klamath Lake, Oregon, June-September 1992-94

[The total number of sampling days during each year at each site is the sum of the three columns under each year; on no sampling day was dissolved oxygen less than 4 milligrams per liter recorded for more than 12 hours; BB, Ball Bay; MN, Midnorth; SB, Shoalwater Bay; --, no data available]

\begin{tabular}{|c|c|c|c|c|c|c|c|c|c|c|}
\hline \multirow[b]{2}{*}{ Month } & \multirow[b]{2}{*}{ Site } & \multicolumn{3}{|c|}{$\begin{array}{c}\text { Number of Hours in } \\
1992\end{array}$} & \multicolumn{3}{|c|}{ Number of Hours in 1993} & \multicolumn{3}{|c|}{ Number of Hours in 1994} \\
\hline & & 0 & $\begin{array}{c}>0 \\
\text { and } \\
<=6\end{array}$ & $\begin{array}{c}>6 \\
\text { and } \\
<=12\end{array}$ & 0 & $\begin{array}{c}>0 \\
\text { and } \\
<=6\end{array}$ & $\begin{array}{c}>6 \\
\text { and } \\
<=12\end{array}$ & 0 & $\begin{array}{c}>0 \\
\text { and } \\
<=6\end{array}$ & $\begin{array}{c}>6 \\
\text { and } \\
<=12\end{array}$ \\
\hline \multirow{3}{*}{ June } & $\mathrm{BB}$ & -- & -- & -- & 21 & 0 & 0 & 28 & 0 & 0 \\
\hline & $\mathrm{MN}$ & 15 & 0 & 0 & 13 & 0 & 0 & 8 & 0 & 0 \\
\hline & SB & -- & -- & -- & 13 & 0 & 0 & 22 & 0 & 0 \\
\hline \multirow{3}{*}{ July } & $\mathrm{BB}$ & -- & -- & -- & 1 & 0 & 0 & 20 & 0 & 0 \\
\hline & $\mathrm{MN}$ & 8 & 0 & 0 & 25 & 1 & 0 & 12 & 0 & 0 \\
\hline & SB & -- & -- & -- & 24 & 0 & 1 & 15 & 1 & 0 \\
\hline \multirow{3}{*}{ August } & BB & 6 & 0 & 0 & 8 & 2 & 2 & 6 & 0 & 0 \\
\hline & $\mathrm{MN}$ & 17 & 1 & 1 & 12 & 0 & 0 & 13 & 1 & 0 \\
\hline & SB & 6 & 0 & 0 & 8 & 2 & 0 & 17 & 6 & 2 \\
\hline \multirow{3}{*}{ September } & $\mathrm{BB}$ & 12 & 0 & 0 & 7 & 0 & 0 & 12 & 0 & 0 \\
\hline & $\mathrm{MN}$ & 9 & 0 & 0 & 27 & 0 & 0 & 25 & 0 & 0 \\
\hline & SB & 18 & 0 & 0 & 25 & 4 & 1 & 6 & 0 & 0 \\
\hline
\end{tabular}


Table 5. Percentage of dissolved oxygen concentrations in the depth-profile dataset less than 4 milligrams per lliter, Upper Klamath and Agency Lakes, Oregon, June-October 1990-94

[Total number of values in parentheses]

\begin{tabular}{cccccc}
\hline Year & June & July & August & September & October \\
\hline 1990 & $0(80)$ & $11.8(93)$ & $14.3(49)$ & $12.3(57)$ & $0(70)$ \\
1991 & $0(68)$ & $0(54)$ & $1.1(89)$ & $3.8(53)$ & $12.8(47)$ \\
1992 & $0(63)$ & $12.4(89)$ & $20.8(53)$ & $3.5(86)$ & $0(85)$ \\
1993 & $0(133)$ & $0(126)$ & $17.1(117)$ & $21.8(87)$ & $2.8(72)$ \\
1994 & $0(131)$ & $8.2(171)$ & $21.8(142)$ & $0(133)$ & $0(149)$ \\
\hline
\end{tabular}

ence between the datasets is explained in large part by the fact that data were recorded below $1-\mathrm{m}$ depth, and very low dissolved oxygen is often recorded near the bottom of the lake even when it is not recorded at $1 \mathrm{~m}$. The following additional information can be inferred from table 5: dissolved oxygen concentrations less than $4 \mathrm{mg} / \mathrm{L}$ did not begin until July in any of the years considered; the greatest frequency of concentrations less than 4 mg/L did not occur until August (as in 1990, 1992, and 1994), September (as in 1993) or even October (as in 1991). Thus, low dissolved oxygen concentration appears to be more of a mid- to late-season problem than an early-season problem. The geographic dependence of the occurrence of dissolved oxygen concentrations less than $4 \mathrm{mg} / \mathrm{L}$ is shown in table 6. In this table the number of measurements of dissolved oxygen concentrations less than $4 \mathrm{mg} / \mathrm{L}$ in the depth-profile dataset are compiled according to location. Agency Lake stations were also included in this analysis. Most notable is the fact that the Eagle Ridge site has the greatest number of low dissolved oxygen values for 4 of the 5 years. This was because the Eagle Ridge site is much deeper than most of the lake. Early in spring, depths at this site are about $8 \mathrm{~m}$, as compared to about $3 \mathrm{~m}$ or less at most other sites, and this area probably is less polymictic. The number of very low dissolved oxygen values tended to be higher at this site (table 6) because the deeper water column there is sampled at the same 1-m interval used in sampling all sites. The number of measurements at Eagle Ridge is even greater in 1994 (fig. 7) because Reclamation sampled at a deeper location than did the Tribes.

Very low concentrations of dissolved oxygen were most often measured at depths of $2 \mathrm{~m}$ or more (fig. 7). A concentration less than $4 \mathrm{mg} / \mathrm{L}$ was measured at the water surface once at Eagle Ridge (August, 1994), once at Shoalwater Bay

Table 6. Number and location of dissolved oxygen concentrations less than 4 milligrams per liter in the depth-profile dataset, Upper Klamath and Agency Lakes, Oregon, June-October 1990-94

[Number of values less than 4 milligrams per liter at each site in parentheses]

\begin{tabular}{|c|c|c|c|c|}
\hline $\begin{array}{c}1990 \\
349 \text { total values }\end{array}$ & $\begin{array}{c}1991 \\
311 \text { total values }\end{array}$ & $\begin{array}{c}1992 \\
376 \text { total values }\end{array}$ & $\begin{array}{c}1993 \\
535 \text { total values }\end{array}$ & $\begin{array}{c}1994 \\
726 \text { total values }\end{array}$ \\
\hline $\begin{array}{l}\text { Eagle Ridge (20) } \\
\text { Agency Lake (South) (3) } \\
\text { Shoalwater Bay (2) }\end{array}$ & $\begin{array}{l}\text { Eagle Ridge (4) } \\
\text { Shoalwater Bay (3) } \\
\text { Midnorth (1) } \\
\text { Wocas Bay (1) }\end{array}$ & $\begin{array}{l}\text { Eagle Ridge (15) } \\
\text { Shoalwater Bay (6) } \\
\text { Wocas Bay (2) } \\
\text { Midnorth (1) } \\
\text { Agency Lake (North) (1) }\end{array}$ & $\begin{array}{l}\text { Eagle Ridge (18) } \\
\text { Shoalwater Bay (9) } \\
\text { Wocas Bay (10) } \\
\text { Agency Lake (South) (4) }\end{array}$ & $\begin{array}{l}\text { Eagle Ridge (33) } \\
\text { Shoalwater Bay (4) } \\
\text { Midnorth (3) } \\
\text { Agency Lake (South) (3) } \\
\text { Midlake (1) } \\
\text { Agency Lake (North) (1) }\end{array}$ \\
\hline
\end{tabular}



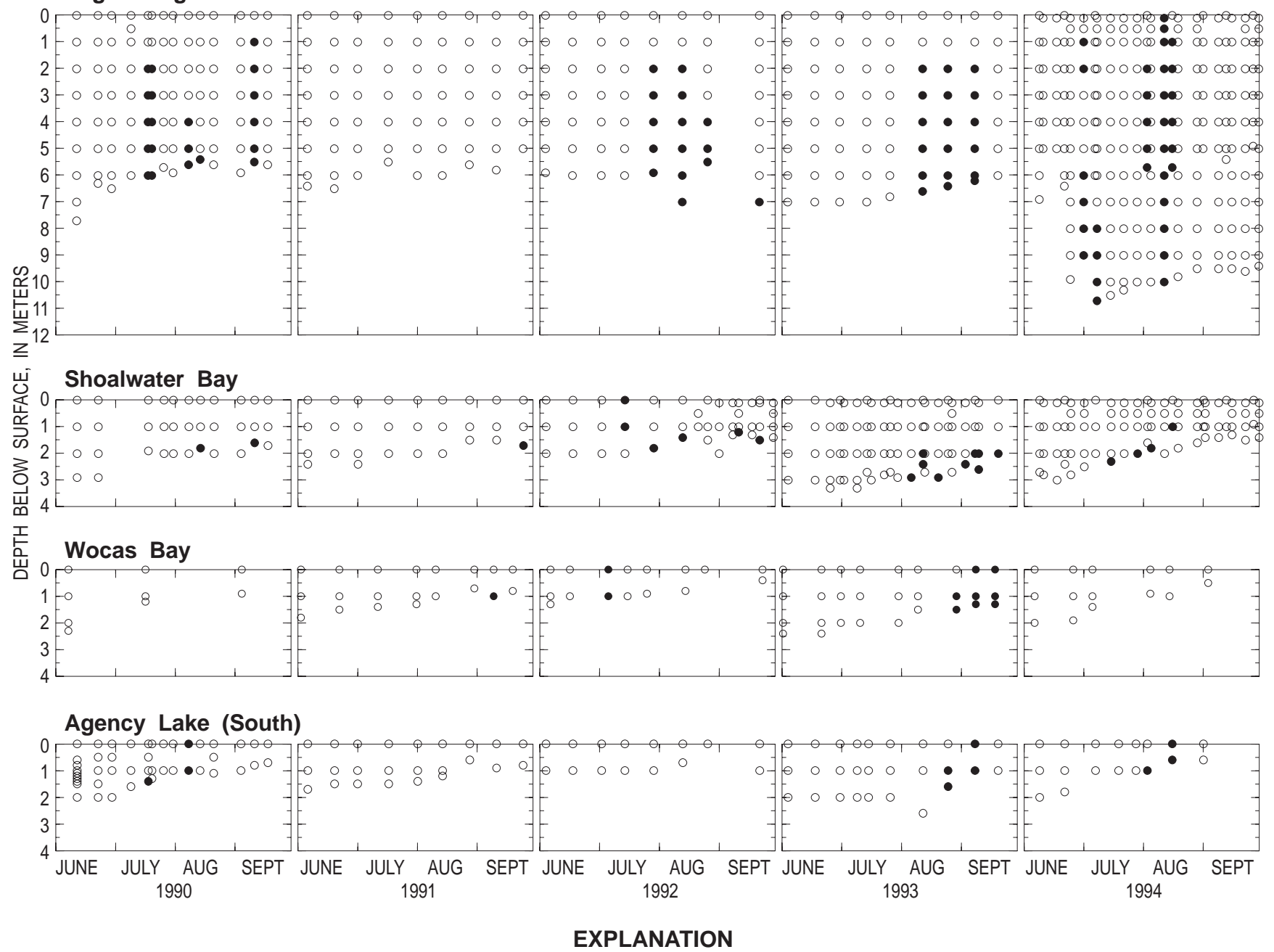

- Dissolved oxygen less than 4 milligrams per liter

- Dissolved oxygen greater than or equal to 4 milligrams per liter

Figure 7. Depth-profile dissolved oxygen data for Eagle Ridge, Shoalwater Bay, Wocas Bay, and Agency Lake (South) sampling sites, Upper Klamath and Agency Lakes, Oregon, June-September 1990-94.

(July, 1992), in 2 different years at Wocas Bay (July, 1992 and September, 1993), and in 3 different years at Agency Lake (South) (August, 1990, September, 1993, and August, 1994).

The greater frequency of low dissolved oxygen in the near-bottom measurements might suggest that the procedure used in taking the near-bottom measurement disturbs bottom sediment, thereby generating additional oxygen demand that lowers the near-bottom values. The protocol used by personnel of both agencies, however, was designed to minimize that possibility. Measurements were made by lowering the Hydrolab slowly and carefully to the bottom and then raising it $10 \mathrm{~cm}$ to take the measurement. Because the bottom of the stirrer cage is about $21 \mathrm{~cm}$ below the probe itself, the measurement was taken a total of roughly $30 \mathrm{~cm}$ from the bottom. The Hydrolab reading was required to stabilize before it was recorded, making it unlikely that a measurement would have been taken if the instrument were moving in and out of a plume of disturbed sediment that was depleted in oxygen compared with the surrounding water (some horizontal and vertical movement of the probe occurs because a boat subject to wave action does not provide a stable platform for lowering the instrument).

Low dissolved oxygen concentration was measured on several consecutive biweekly sampling dates, most notably in 1992 and 1993 (fig. 
7). Because these profiles were taken during the day, usually between late morning and mid-afternoon, it is likely that very low dissolved oxygen concentrations near the bottom can persist longer than the brief time periods indicated in the hourly records at 1-m depth, and that they occur with greater frequency (on more days per month, for example).

In figure 7 it is easy to see the data values that, because of the differing locations used by the Tribes and Reclamation, were recorded at greater depths in 1994 than in the other years. The difference in sampling locations created a problem in some analyses of the data distribution, because the Eagle Ridge site was inequitably weighted in 1994. Where appropriate, the resulting implications for the analyses are discussed below.

\section{pH}

The analyses presented above for dissolved oxygen concentrations were repeated for $\mathrm{pH}$. During many of the days in June 1994 for which hourly records were available at three moored sta- tions, $\mathrm{pH}$ at $1-\mathrm{m}$ depth was greater than 9.5 for more than 18 hours (table 7). At Ball Bay and Shoalwater Bay, similar conditions extended into July of that year. Excursions into very high $\mathrm{pH}$ values lasted for a large fraction of the day or even for days at a time. Values of $\mathrm{pH}$ greater than 9.5 were more frequent in the earlier part of the season, especially June. It is especially unfortunate that there was no coverage at Ball Bay or Shoalwater Bay during June and July of 1992; the data from Midnorth indicates that the $\mathrm{pH}$ there was often greater than 9.5 during that time.

The profile data reinforce the result that very high $\mathrm{pH}$ conditions occur most frequently early in the season, but they also show that during 1990 and 1991, years not covered by hourly records, a high frequency of $\mathrm{pH}$ values greater than 9.5 occurred in August and September (table 8). Therefore, the profile data indicate that very high $\mathrm{pH}$ values were not necessarily limited to the early part of the season. An analysis of the geographic dependence of very high $\mathrm{pH}$ conditions (table 9) shows that many sites around the lake were affected. In fact, when high $\mathrm{pH}$ values were recorded, it was common to record them at most of

Table 7. Number of sampling days at hourly record sites, grouped by the number of hours that pH was greater than 9.5 during the day, Upper Klamath Lake, Oregon, June-September 1992-94

[The total number of sampling days during each year at each site is the sum of the five columns under each year; BB, Ball Bay; MN, Midnorth; SB, Shoalwater Bay; --, no data available]

\begin{tabular}{|c|c|c|c|c|c|c|c|c|c|c|c|c|c|c|c|c|}
\hline \multirow[b]{2}{*}{ Month } & \multirow[b]{2}{*}{ Site } & \multicolumn{5}{|c|}{ Number of Hours in 1992} & \multicolumn{5}{|c|}{ Number of Hours in 1993} & \multicolumn{5}{|c|}{ Number of Hours in 1994} \\
\hline & & 0 & $\begin{array}{c}>0 \\
\text { and } \\
<=6\end{array}$ & $\begin{array}{c}>6 \\
\text { and } \\
<=12\end{array}$ & $\begin{array}{c}>1 \\
\text { and } \\
<=18\end{array}$ & $\begin{array}{l}>18 \\
\text { and } \\
<=24\end{array}$ & 0 & $\begin{array}{c}>0 \\
\text { and } \\
<=6\end{array}$ & $\begin{array}{c}>6 \text { and } \\
<=12\end{array}$ & $\begin{array}{l}>12 \\
\text { and } \\
<=18\end{array}$ & $\begin{array}{c}>18 \\
\text { and } \\
<=24\end{array}$ & 0 & $\begin{array}{c}>0 \\
\text { and } \\
<=6\end{array}$ & $\begin{array}{c}>6 \\
\text { and } \\
<=12\end{array}$ & $\begin{array}{c}>12 \\
\text { and } \\
<=18\end{array}$ & $\begin{array}{l}>18 \\
\text { and } \\
<=24\end{array}$ \\
\hline \multirow{3}{*}{ June } & $\mathrm{BB}$ & -- & -- & -- & -- & -- & 14 & 5 & 3 & 0 & 0 & 8 & 3 & 1 & 3 & 14 \\
\hline & $\mathrm{MN}$ & 5 & 2 & 1 & 1 & 6 & 12 & 1 & 0 & 0 & 0 & 4 & 1 & 3 & 1 & 6 \\
\hline & SB & -- & -- & -- & -- & -- & 11 & 2 & 2 & 0 & 0 & 9 & 3 & 2 & 2 & 6 \\
\hline \multirow{3}{*}{ July } & $\mathrm{BB}$ & -- & -- & -- & -- & -- & 7 & 0 & 4 & 1 & 3 & 5 & 5 & 3 & 3 & 4 \\
\hline & $\mathrm{MN}$ & 10 & 0 & 0 & 1 & 5 & 23 & 4 & 1 & 2 & 1 & 6 & 0 & 1 & 1 & 1 \\
\hline & SB & -- & -- & -- & -- & -- & 19 & 4 & 4 & 0 & 1 & 1 & 5 & 2 & 1 & 7 \\
\hline \multirow{3}{*}{ August } & $\mathrm{BB}$ & 0 & 6 & 0 & 0 & 0 & 25 & 2 & 2 & 0 & 2 & 6 & 0 & 0 & 0 & 0 \\
\hline & $\mathrm{MN}$ & 18 & 1 & 0 & 0 & 0 & 14 & 1 & 0 & 0 & 0 & 14 & 0 & 0 & 0 & 0 \\
\hline & SB & 6 & 0 & 0 & 0 & 0 & 24 & 0 & 0 & 0 & 0 & 22 & 3 & 0 & 0 & 0 \\
\hline \multirow{3}{*}{ September } & BB & 12 & 0 & 0 & 0 & 0 & 30 & 0 & 0 & 0 & 0 & 12 & 0 & 0 & 0 & 0 \\
\hline & $\mathrm{MN}$ & 9 & 0 & 0 & 0 & 0 & 27 & 0 & 0 & 0 & 0 & 25 & 0 & 0 & 0 & 0 \\
\hline & SB & 18 & 0 & 0 & 0 & 0 & 30 & 0 & 0 & 0 & 0 & 6 & 0 & 0 & 0 & 0 \\
\hline
\end{tabular}


Table 8. Percentage of $\mathrm{pH}$ values in the depth-profile dataset greater than 9.5, Upper Klamath and Agency Lakes, Oregon, June-October 1990-94

[Total number of values in parentheses]

\begin{tabular}{llllll}
\hline Year & \multicolumn{1}{c}{ June } & \multicolumn{1}{c}{ July } & \multicolumn{1}{c}{ August } & September & October \\
\hline 1990 & $45(80)$ & $40.9(93)$ & $6.1(49)$ & $36.8(57)$ & $0(70)$ \\
1991 & $0(68)$ & $57.4(54)$ & $18.0(72)$ & $67.9(53)$ & $2.1(47)$ \\
1992 & $65.1(63)$ & $4.5(89)$ & $0(53)$ & $6.9(87)$ & $0(85)$ \\
1993 & $16.5(133)$ & $57.9(126)$ & $6.8(117)$ & $0(87)$ & $0(72)$ \\
1994 & $68.2(132)$ & $65.5(171)$ & $2.1(142)$ & $0(131)$ & $0(149)$ \\
\hline
\end{tabular}

Table 9. Number and location of $\mathrm{pH}$ values in the depth-profile dataset greater than 9.5, Upper Klamath and Agency Lakes, Oregon, June-October 1990-94

[Number of values greater than 9.5 at each site in parentheses next to the corresponding site]

\begin{tabular}{|c|c|c|c|c|}
\hline $\begin{array}{c}1990 \\
349 \text { total values }\end{array}$ & $\begin{array}{c}1991 \\
294 \text { total values }\end{array}$ & $\begin{array}{c}1992 \\
377 \text { total values }\end{array}$ & $\begin{array}{c}1993 \\
535 \text { total values }\end{array}$ & $\begin{array}{c}1994 \\
725 \text { total values }\end{array}$ \\
\hline Agency Lake (South) (31) & Midlake (11) & Shoalwater Bay (9) & North Buck Island (20) & Eagle Ridge (81) \\
\hline Midnorth (24) & Wocas Bay (10) & Eagle Ridge (9) & Shoalwater Bay (17) & North Buck Island (31) \\
\hline Eagle Ridge (17) & Eagle Ridge (10) & Agency Lake (North) (8) & Midlake (15) & Midnorth (29) \\
\hline Shoalwater Bay (11) & Shoalwater Bay (9) & Midnorth (6) & Agency Lake (North) (13) & Shoalwater Bay (27) \\
\hline North Buck Island (3) & Midnorth (8) & Midlake (4) & Wocas Bay (8) & Agency Lake (North) (7) \\
\hline \multirow[t]{2}{*}{ Midlake (3) } & Agency Lake (North) (8) & Wocas Bay (3) & Pelican Marina (8) & Wocas Bay (6) \\
\hline & Agency Lake (South) (8) & North Buck Island (3) & Eagle Ridge (2) & Pelican Marina (6) \\
\hline
\end{tabular}

the sites around the lake. The depth profiles also show that conditions of very high $\mathrm{pH}$ at the shallower sites generally extended throughout the water column (fig. 8). The $\mathrm{pH}$ data generally had little vertical variation, or values were slightly higher at the surface.

\section{Un-ionized Ammonia}

The breakdown of proteinaceous organic matter and urea results in releases of the ammonium ion $\left(\mathrm{NH}_{4}{ }^{+}\right)$(U.S. Environmental Protection Agency, 1986). The ammonium ion in water is in chemical equilibrium with un-ionized ammonia $\left(\mathrm{NH}_{3}\right)$, a nitrogen species that is toxic to freshwater aquatic life above certain concentrations. The fraction of ammonia in the un-ionized form increases markedly with $\mathrm{pH}$. For example, at $20^{\circ} \mathrm{C}$ and $\mathrm{pH} 7,0.4 \%$ of the total ammonia $\left(\mathrm{NH}_{3}\right.$ plus $\left.\mathrm{NH}_{4}^{+}\right)$is in the un-ionized form, but at $20^{\circ} \mathrm{C}$ and $\mathrm{pH} 9$, the fraction increases to $28 \%$ (Bowie and others, 1985). A combination of high ammonia concentration and high $\mathrm{pH}$ is required to produce un-ionized ammonia in concentrations that are harmful to fish. Possible sources of ammonia to Upper Klamath Lake include runoff from agricultural, range, and forested landscapes (especially during spring snowmelt) in addition to the release of ammonia from nitrogen-bearing sediment in Upper Klamath Lake. Additional sources of nitrogen within the lakes include the decay of aquatic plants and algal blooms, excretory products from lake biota, and bacterially-mediated processes that transform nitrates into ammonia within the sediments. 

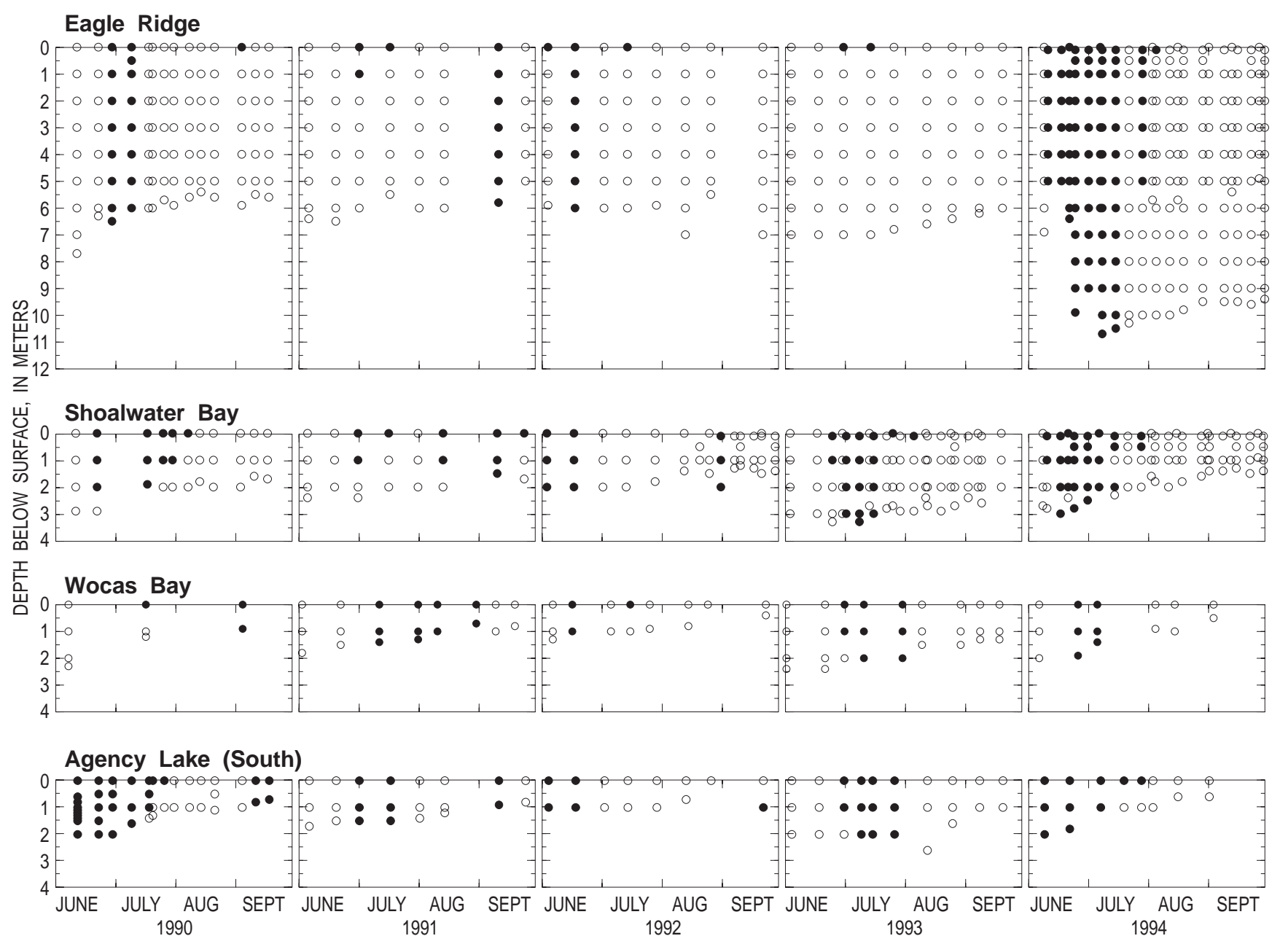

EXPLANATION

- $\mathrm{pH}$ greater than 9.5

- $\mathrm{pH}$ less than or equal to 9.5

Figure 8. Depth-profile pH data for Eagle Ridge, Shoalwater Bay, Wocas Bay, and Agency Lake (South) sampling sites, Upper Klamath and Agency Lakes, Oregon, June-September 1990-94.

Un-ionized ammonia concentration was calculated from total ammonia concentrations, $\mathrm{pH}$, and temperature using the equilibrium calculation in Bowie and others (1985), and all available data for the period 1990-94 from nine regularly sampled sites in Upper Klamath and Agency Lakes. On the basis of annual medians for all sites combined, the highest un-ionized ammonia concentration $(0.020 \mathrm{mg} / \mathrm{L}$ as $\mathrm{N})$ was measured in 1990 and the lowest concentration was measured in 1993 $(0.001 \mathrm{mg} / \mathrm{L}$ as $\mathrm{N})$. The 1990 concentration was 5 to 17 times that of median concentrations for the period 1991-94. The significance of the calculated un-ionized ammonia concentrations with respect to freshwater aquatic biota was determined by comparing the ammonia data to guidelines for acute and chronic toxicity developed for salmonids or other coldwater species and to experimentally determined $\mathrm{LC}_{50} \mathrm{~s}$.

The equations for calculating toxicity guidelines for un-ionized ammonia concentration (U.S. Environmental Protection Agency, 1986) are valid for $\mathrm{pH}$ values ranging from 6.5 to 9 . It is not permissible under current water-quality guidelines to extrapolate beyond the 6.5 to 9.0 range of $\mathrm{pH}$ in evaluating the toxicity of un-ionized ammonia to aquatic life (U.S. Environmental Protection Agency, 1986)—data falling outside the permissible range were not evaluated in the present study. Coefficients in the USEPA's un-ionized ammonia 
equations have since been modified (Margarete Heber, USEPA, written commun., July 30, 1992) and exceedances listed in this report were determined on the basis of the updated coefficients.

Un-ionized ammonia was present in Upper Klamath Lake in concentrations that exceed the chronic (4-day average) guideline for salmonids or other sensitive cold water species (table 10); none of the un-ionized ammonia concentrations, however, exceeded the acute (1-hour average) guideline. Additionally, the number of chronic exceedances was small-about $4 \%$ of the 646 total ammonia determinations (excluding ammonia data

Table 10. Number of un-ionized ammonia concentrations exceeding the chronic 4-day average guideline by year and site, Upper Klamath Lake, Oregon, 1990-94

[Exceedances were determined on the basis of a single measurement of total ammonia. "All sites" indicates all sites sampled for ammonia by the Klamath Tribes and includes: Agency Lake (North) (AN), Agency Lake (South) (AS), Agency Lake Weather Station (AW), Eagle Ridge (ER), Fremont Bridge (FB), Midlake (ML), Midnorth (MN), North Buck Island (NB), Pelican Bay (PB), Pelican Marina (PM), Shoalwater Bay (SB), and Wocas Bay (WB)]

\begin{tabular}{|c|c|c|}
\hline Site & $\begin{array}{c}\text { Number of } \\
\text { exceedances }\end{array}$ & $\begin{array}{c}\text { Total number of } \\
\text { samples }\end{array}$ \\
\hline \multicolumn{3}{|c|}{1990} \\
\hline AS & 1 & 16 \\
\hline ER & 3 & 16 \\
\hline $\mathrm{MN}$ & 1 & 16 \\
\hline SB & 2 & 13 \\
\hline WB & 1 & 3 \\
\hline All sites & 8 & 104 \\
\hline \multicolumn{3}{|c|}{1991} \\
\hline ER & 2 & 12 \\
\hline MN & 1 & 12 \\
\hline PM & 1 & 12 \\
\hline SB & 1 & 12 \\
\hline WB & 1 & 11 \\
\hline All sites & 6 & 117 \\
\hline \multicolumn{3}{|c|}{1992} \\
\hline ER & 1 & 17 \\
\hline SB & 1 & 17 \\
\hline WB & 1 & 14 \\
\hline All sites & 3 & 155 \\
\hline \multicolumn{3}{|c|}{1993} \\
\hline ER & 1 & 13 \\
\hline MN & 3 & 14 \\
\hline NB & 1 & 14 \\
\hline PM & 1 & 15 \\
\hline WB & 1 & 14 \\
\hline All sites & 7 & 141 \\
\hline \multicolumn{3}{|c|}{1994} \\
\hline FB & 1 & 7 \\
\hline $\mathrm{PM}$ & 1 & 10 \\
\hline All sites & 2 & 129 \\
\hline \multicolumn{3}{|c|}{ 1990-94 } \\
\hline All sites & 26 & 646 \\
\hline
\end{tabular}

with $\mathrm{pH}$ values outside the acceptable range in $\mathrm{pH}$ from 6.5 to 9 and without an accompanying measurement of water temperature). The number of chronic exceedances differed slightly among years. The number of exceedances comprised as little as $2 \%$ of the total number of ammonia determinations in 1992 and 1994 and as large as $8 \%$ in 1990. However, comparisons of exceedances among years are qualitative. Some sites were not sampled each year, and others had variable sampling frequencies.

Because the un-ionized ammonia toxicity equation has an upper $\mathrm{pH}$ limit of 9 , nearly $40 \%$ (247 of 646 determinations) of the total number of ammonia determinations for the period 1990-94 were not evaluated for un-ionized ammonia toxicity. Of these data, many of the total and un-ionized ammonia concentrations measured in 1990 exceeded concentrations in subsequent years (fig. 9). For example, the interquartile range ( 0.012 to 0.080 $\mathrm{mg} / \mathrm{L}$ as $\mathrm{N}$ ) and median un-ionized ammonia concentration $(0.040 \mathrm{mg} / \mathrm{L}$ as $\mathrm{N})$ in 1990 was at least 3

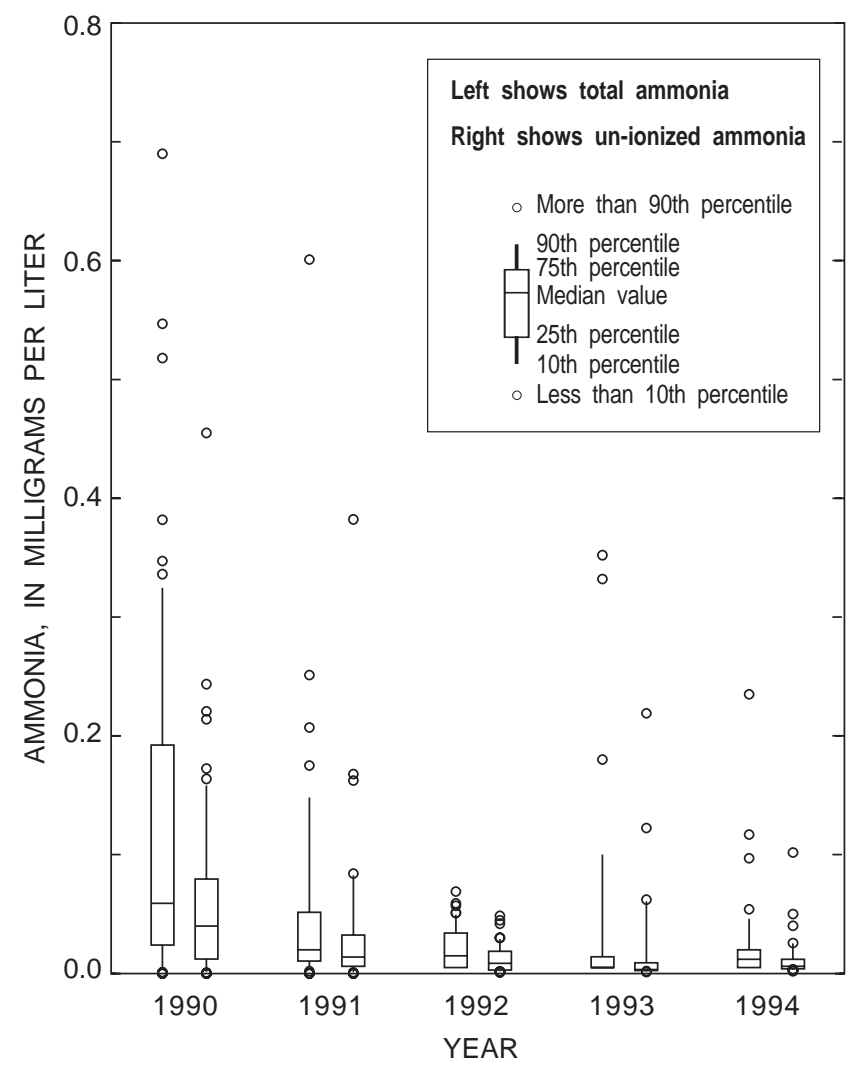

Figure 9. Frequency distributions of total ammonia and un-ionized ammonia concentrations for $\mathrm{pH}$ values greater than 9, Upper Klamath and Agency Lakes, Oregon, 1990-94. 
times that measured in subsequent years. The higher un-ionized ammonia concentrations in 1990 (for $\mathrm{pH}$ greater than 9) also coincide in time with the occurrence of a slightly larger number of chronic-ammonia exceedances (for $\mathrm{pH}$ within the acceptable 6.5 to 9.0 criterion range).

Comparison to experimentally determined $\mathrm{LC}_{50} \mathrm{~s}$ was not limited to any subset of the data. Two data values $(0.38$ and $0.46 \mathrm{mg} / \mathrm{L}$ of un-ionized ammonia) for the period 1990-94 exceeded the lowest experimentally determined $\mathrm{LC}_{50}$ for larval and juvenile shortnose and Lost River suckers, which was $0.34 \mathrm{mg} / \mathrm{L}$.

\section{HYPOTHESES RELATING SELECTED WATER-QUALITY VARIABLES TO LAKE LEVEL}

Prior to discussing how year-to-year differences in water quality relate to year-to-year differences in lake level, it is helpful to examine how the lake levels during the years used in the analysis, 1990-94, compare to each other and to the historical record (fig. 10). Two points should be made.

First, the order of the ranking of 1990-94 remains consistent through the summer-from low to high the years rank as 1992, 1994, 1991, 1990, and 1993 (1992 and 1994 were reversed at the end of July, but the difference in end-of-July lake levels between those two years was small). For that reason, and because it makes comparisons from lower to higher lake level easier, frequency distributions of the data from each year will be presented in that order. Second, even though the ranking remained the same, the relative difference between each of the years was not fixed. For example, at the end of June, the 1994 lake level (4140.81 ft) was closer to the 1991 lake level $(4141.51 \mathrm{ft})$ than to the 1992 lake level (4139.45 ft), but by the end of July, 1992 and 1994 lake levels were very similar (4138.77 and $4139.04 \mathrm{ft}$, respectively) and more than $1 \mathrm{ft}$ lower than the level in 1991 (4140.2 ft).

The low end of post-dam lake levels is represented by 1992; levels in that year were consistently below the 10th percentile of the post-dam (1922-present) end-of-month levels. In 1993, the highest-lake-level year of the 5 years considered in this analysis, lake level was above the 90th per-

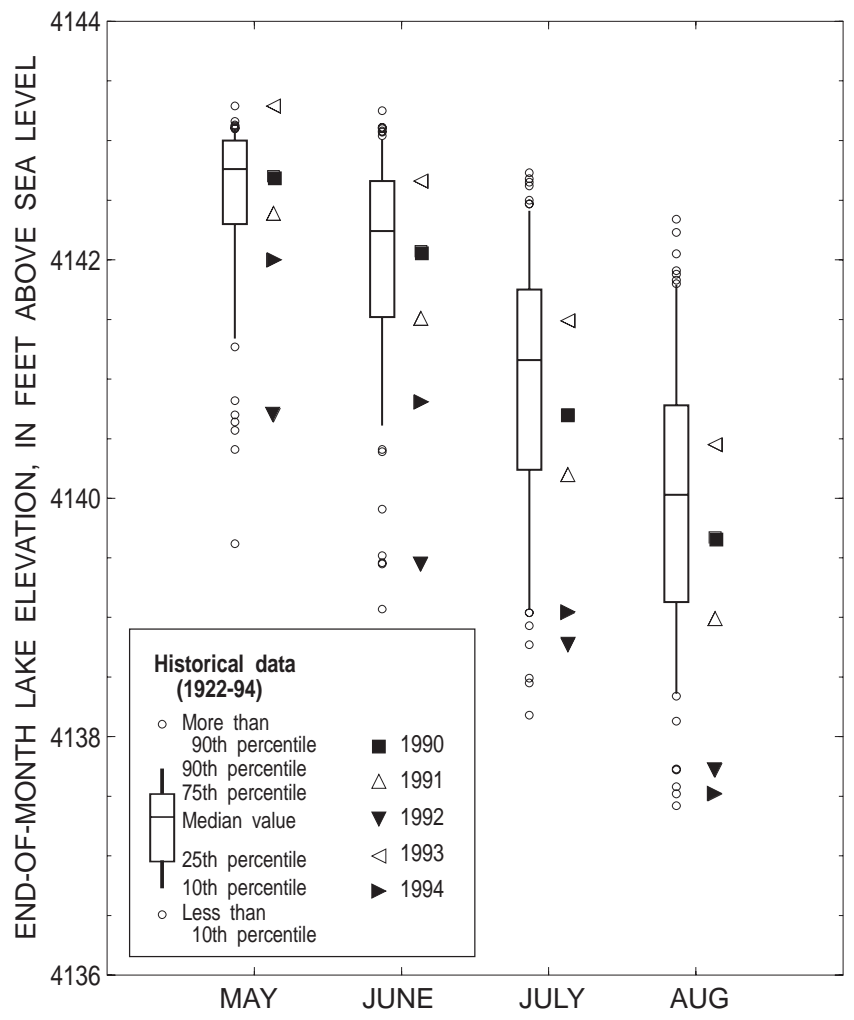

Figure 10. Comparison of May through August end-of-month lake elevation for 1990-94 with the frequency distribution of the historical, post-dam end-of-month values for 1922-94, Upper Klamath Lake, Oregon.

centile of the post-dam historical record in May, but by the end of July was between the 50th and 75th percentile. A large overall range in lake level is represented in the 1990-94 dataset, including the low end of the post-dam range; the high end of the June-September post-dam range, however, is not represented.

\section{Chlorophyll-a}

A general statement of the hypothesis relating chlorophyll- $a$ to lake level is:

\section{Hypothesis 1: Year-to-year differences in chlorophyll-a concentration are related to year-to-year differences in lake level, such that chlorophyll-a concentrations are lower at higher lake levels.}

The temporal progression of chlorophyll- $a$ concentration at the regularly sampled sites around the lake (fig. 11) shows that concentration rose more rapidly and peaked in June at a higher value in 1992 than in any of the other years. Nonetheless, 1992 

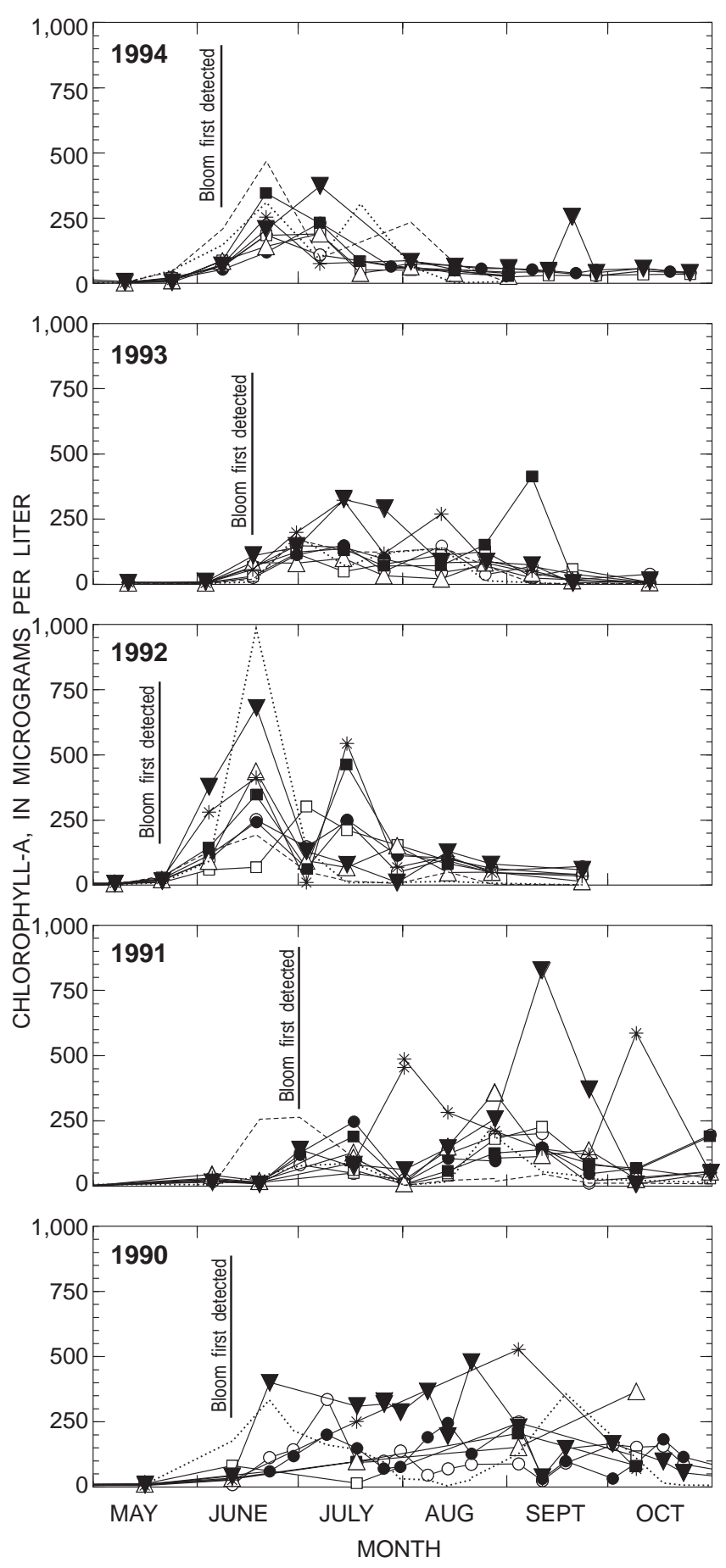

EXPLANATION

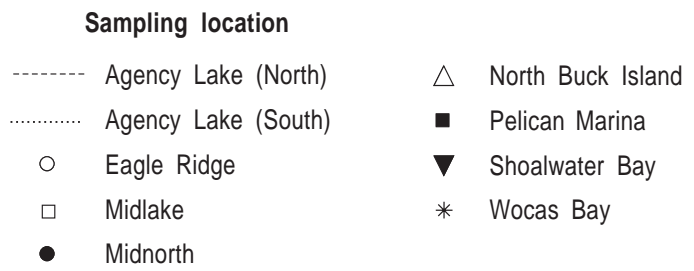

Figure 11. Chlorophyll-a concentration at selected sites, Upper Klamath and Agency Lakes, Oregon, May-October 1990-94. chlorophyll- $a$ concentrations were not higher through the entire May-October period; high concentrations were sustained the longest in 1990 and 1991, and to a lesser extent in 1993. Quantitative measures such as the seasonal median concentration confirm that observation: the May-October median concentration of chlorophyll- $a$ in Upper Klamath Lake was $99 \mu \mathrm{g} / \mathrm{L}$ in $1990,71 \mu \mathrm{g} / \mathrm{L}$ in $1991,68 \mu \mathrm{g} / \mathrm{L}$ in $1992,52 \mu \mathrm{g} / \mathrm{L}$ in 1993 , and $52 \mu \mathrm{g} / \mathrm{L}$ in 1994. The Agency Lake data also show the highest seasonally averaged growth in 1990 , but the second-highest in 1994-seasonal median concentrations were $111 \mu \mathrm{g} / \mathrm{L}$ in $1990,28 \mu \mathrm{g} / \mathrm{L}$ in $1991,13 \mu \mathrm{g} / \mathrm{L}$ in $1992,13 \mu \mathrm{g} / \mathrm{L}$ in 1993 , and $80 \mu \mathrm{g} / \mathrm{L}$ in 1994 . In both lakes, the very large June bloom in 1992 did not lead to sustained algal growth through the summer and a high seasonal median chlorophyll- $a$ concentration.

The sampling date on which the first bloom was detected was defined as the first sampling date when a chlorophyll- $a$ concentration of $20 \mu \mathrm{g} / \mathrm{L}$ or greater was measured, with one exception. In 1991 the first sampling date when this concentration was measured was June 5, but by the next sampling date (June 19) the bloom had clearly stalled. Therefore, the sampling date used as the detection date of the bloom in 1991 was the second date when a concentration of $20 \mu \mathrm{g} / \mathrm{L}$ was detected, which was July 1 . In figure 12 the number of days from April 1 to the date when the bloom was detected is plotted against the lake level on May 1, with the corresponding year indicated next to each point. The lower bar on each point indicates the previous sampling date, and the number of days from that date to the detection date is an indication of the maximum potential error in the detectiondate point. May 1 lake level was used because that date precedes the onset of the bloom in any year, but the results did not change qualitatively when either the second quarter median lake level or June 1 lake level was used.

A relation between lake level and the date of detection is indicated for all of the years except 1991. The years 1991 and 1994 had similar lake levels but differed greatly in the timing of the first bloom. For comparison, the first sample date in 1991 on which a median concentration of chlorophyll- $a$ greater than $20 \mu \mathrm{g} / \mathrm{L}$ was measured is shown as an open circle, and that point fits the overall pattern. Perhaps the 1991 bloom started to 


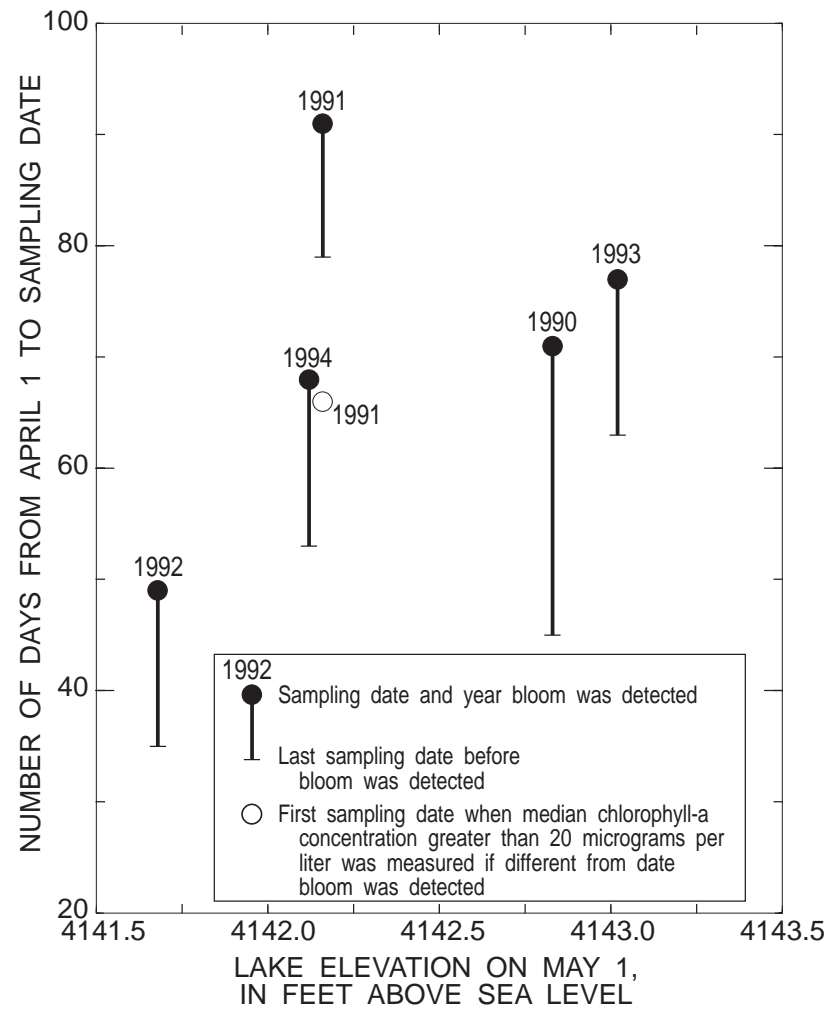

Figure 12. Relation of lake elevation on May 1 to the number of days from April 1 to the sampling date on which the algal bloom was first detected, Upper Klamath Lake, Oregon, 1990-94.

behave as would be predicted by lake level in early June, but some other factor became important, arresting the early onset of the bloom and delaying the true onset until much later. Biweekly sampling can result in error bars that are a large fraction of the differences between years, but there is still an indication of an apparent trend toward later blooms at higher lake level.

The chlorophyll- $a$ data were grouped by month and the frequency distributions were plotted for each year in a boxplot format (fig. 13). The median, 25th-, and 75th- percentile June concentrations were higher in 1992 and 1994 than in any of the other 3 years. By July, however, the distributions (as measured by the median or 25 th percentile) were similar across all the years, although the highest concentrations were still found in 1992. In August and September, chlorophyll- $a$ concentrations in 1991 and 1990 had a higher distribution (as measured by the median, 75th percentile, or 90th percentile of concentration) than any of the other 3 years. Therefore, it is only

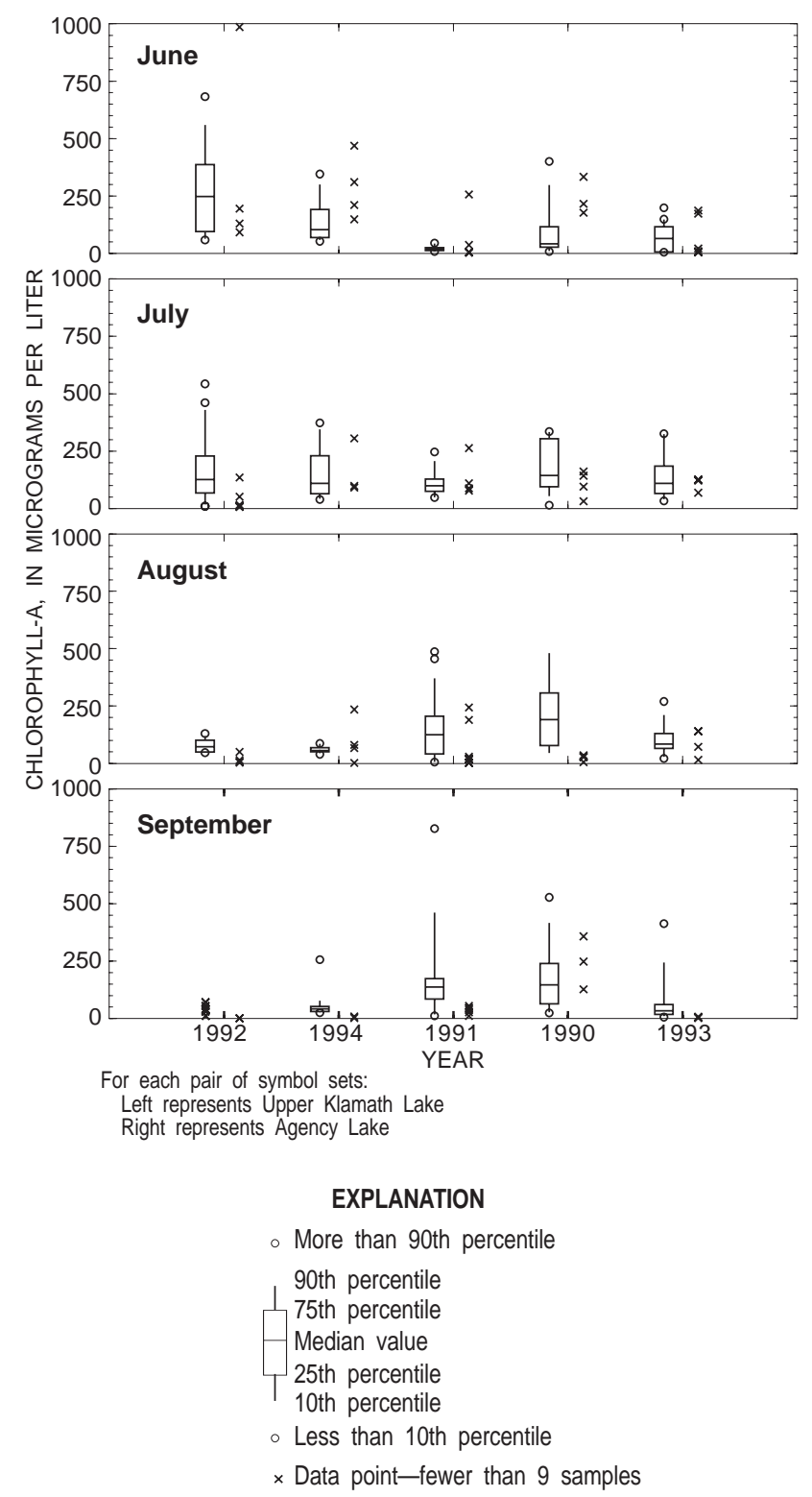

Figure 13. Frequency distributions of lakewide chlorophyll-a data, by month, Upper Klamath and Agency Lakes, Oregon, June-September 1990-94. The years are ranked in order of increasing lake elevation.

during the earliest part of the season that the relation stated in Hypothesis 1 is apparent.

The chlorophyll- $a$ data collected at each site on each June sampling date were plotted against the lake level on that sampling date (fig. 14). The highest chlorophyll- $a$ concentrations in both Upper Klamath and Agency Lakes were measured at the lowest lake levels, in particular on the 6/17/92 sampling date. With the exception of 1991, chlorophyll- $a$ concentration increased in every year between the first and the second June sampling date, but was already as high on 6/3/92 


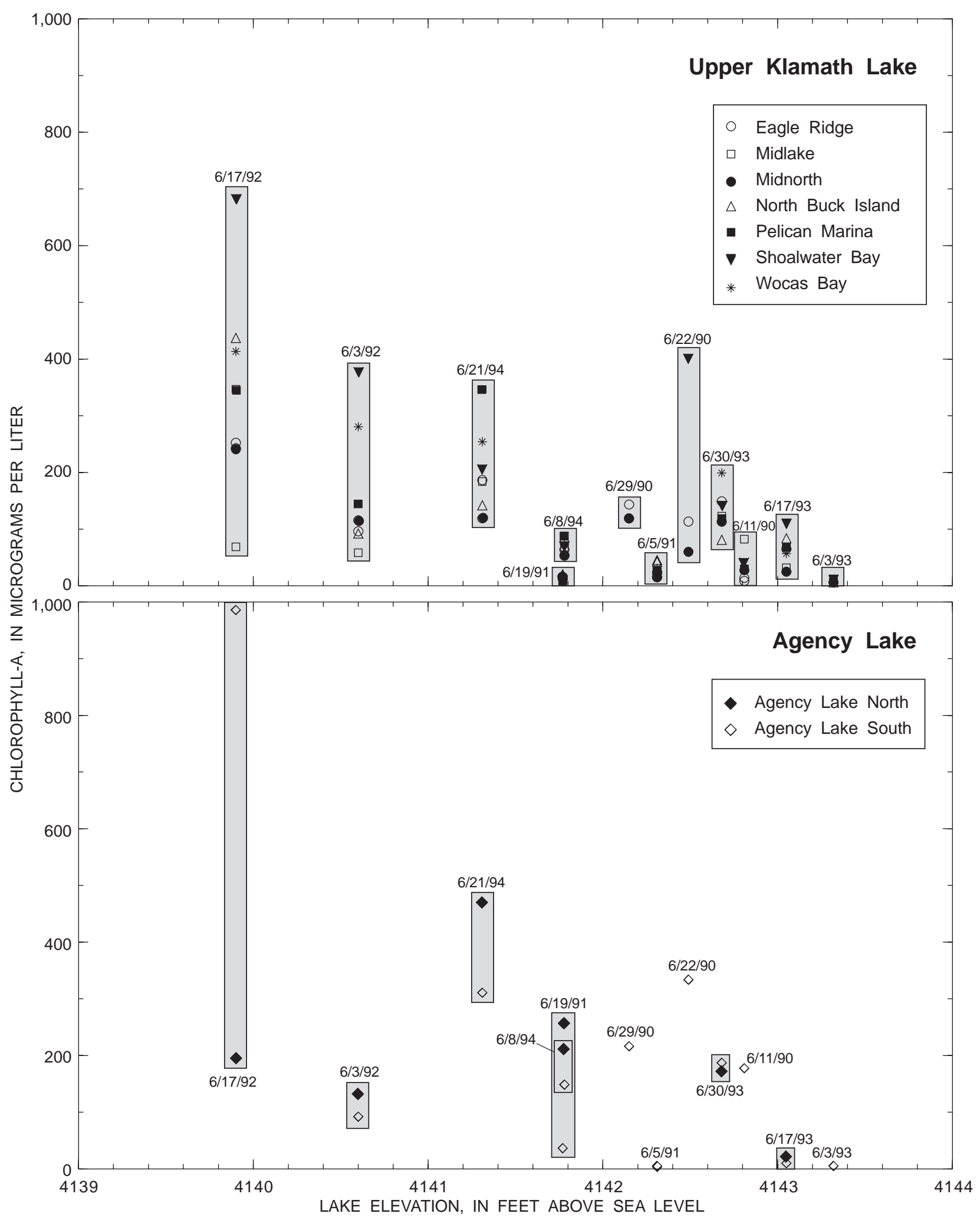

Figure 14. Relation of chlorophyll-a concentration to lake elevation, Upper Klamath and Agency Lakes, Oregon, June 1990-94. The corresponding year is noted next to each data point. 
as it was much later in the month in 1994 and 1990 (6/21/94 and 6/22/90). Between 6/11/90 and 6/22/ 90, the increase in chlorophyll- $a$ at Shoalwater Bay was comparable to the increase at the site that had the highest concentration in 1994 (see the Pelican Marina data on 6/8/94 and 6/21/94). Only three sites were sampled on $6 / 22 / 90$ and two on $6 /$ 29/90, and because chlorophyll- $a$ concentration at Midnorth and Eagle Ridge remained below 150 $\mu \mathrm{g} / \mathrm{L}$ during June of 1990 , the median concentration was also relatively low (fig. 13). It is likely, however, that had more sites been sampled during that month, the June 1990 median concentrations would have been higher, and perhaps comparable to those in 1994.

The chlorophyll- $a$ data are consistent with the following hypotheses, more specific than Hypothesis 1, that relate chlorophyll- $a$ to lake level:

Hypothesis 2: Year-to-year differences in the timing of the first bloom are related to year-to-year differences in June lake level, such that the first bloom is delayed at higher lake levels.

Hypothesis 3: Year-to-year differences in June chlorophyll-a concentrations are related to year-to-year differences in June lake level, such that June chlorophyll-a concentration is lower at higher lake levels.

These hypotheses are supported by the contrast between 1992 and 1993, the 2 years at the low and high ends of the range in lake level, in both Upper Klamath and Agency Lakes. The phenomenon described in Hypothesis 3 is, in large part, a result of that described in Hypothesis 2. Chlorophyll- $a$ concentrations well over $200 \mu \mathrm{g} / \mathrm{L}$ were already apparent at the beginning of June in 1992, much earlier than in the other 4 years. By the end of June in 1993, chlorophyll- $a$ still was not measured at that concentration. Some evidence that low lake level is also associated with a higher peak concentration of the first bloom is provided by the 1992 data, which show that 1992 had both an earlier bloom and a stronger bloom than any other year.

A large middle range in June lake level is represented by the years 1990, 1991, and 1994. Of these, 1991 is anomalous in that there was no increase in chlorophyll- $a$ between the June sampling dates. This year is almost certainly an indicator of the influence of weather on algal growth in Upper Klamath Lake (see discussion in the section "Hypotheses Relating Water Quality to Climatic Variables"), although substantial chlorophyll-a was measured at an Agency Lake site in 1991. Interpretation of the 1990 data was hampered by a paucity of data because relatively few sites were sampled during the latter half of June, but there is an indication that a bloom comparable in timing and magnitude to that of 1994 was underway. The 1994 bloom had characteristics between those of 1992 and 1993. In 1994 the bloom started later than in 1992 and earlier than in 1993, and peaked in Upper Klamath Lake at a higher value (median concentration $187 \mu \mathrm{g} / \mathrm{L}$ on June 21) than the 1993 bloom (median concentration $142 \mu \mathrm{g} / \mathrm{L}$ on July 14 ) and at a lower value than the 1992 bloom (median concentration $347 \mu \mathrm{g} / \mathrm{L}$ on June 17).

\section{pH}

A general statement of the hypothesis relating $\mathrm{pH}$ to lake level is as follows:

\section{Hypothesis 4: Year-to-year differences in the frequency of occurrence of $\mathrm{pH}$ values greater than 9.5 are related to year-to-year differences in lake level, such that the frequency is lower at higher lake level.}

$\mathrm{pH}$ fluctuates over the day and usually reaches a daily maximum value late in the afternoon. Therefore, the diel maximum in $\mathrm{pH}$ was recorded only at 1-m depth and at three sitesMidnorth, Shoalwater Bay, and Ball Bay-where fixed-depth Hydrolabs were deployed. The hourly Hydrolab records were screened for maximum $\mathrm{pH}$ values over the day, and days with inadequate coverage (less than 20 of 24 hours) were dropped from the analysis. The daily maxima were plotted against lake elevation for the time period June-September (fig. 15). Day-to-day fluctuations in the daily maximum $\mathrm{pH}$ were usually less than 1 $\mathrm{pH}$ unit and, as a result, the seasonal pattern is clearly evident. As lake level drops from June to September (see fig. 5), the daily maximum $\mathrm{pH}$ first 

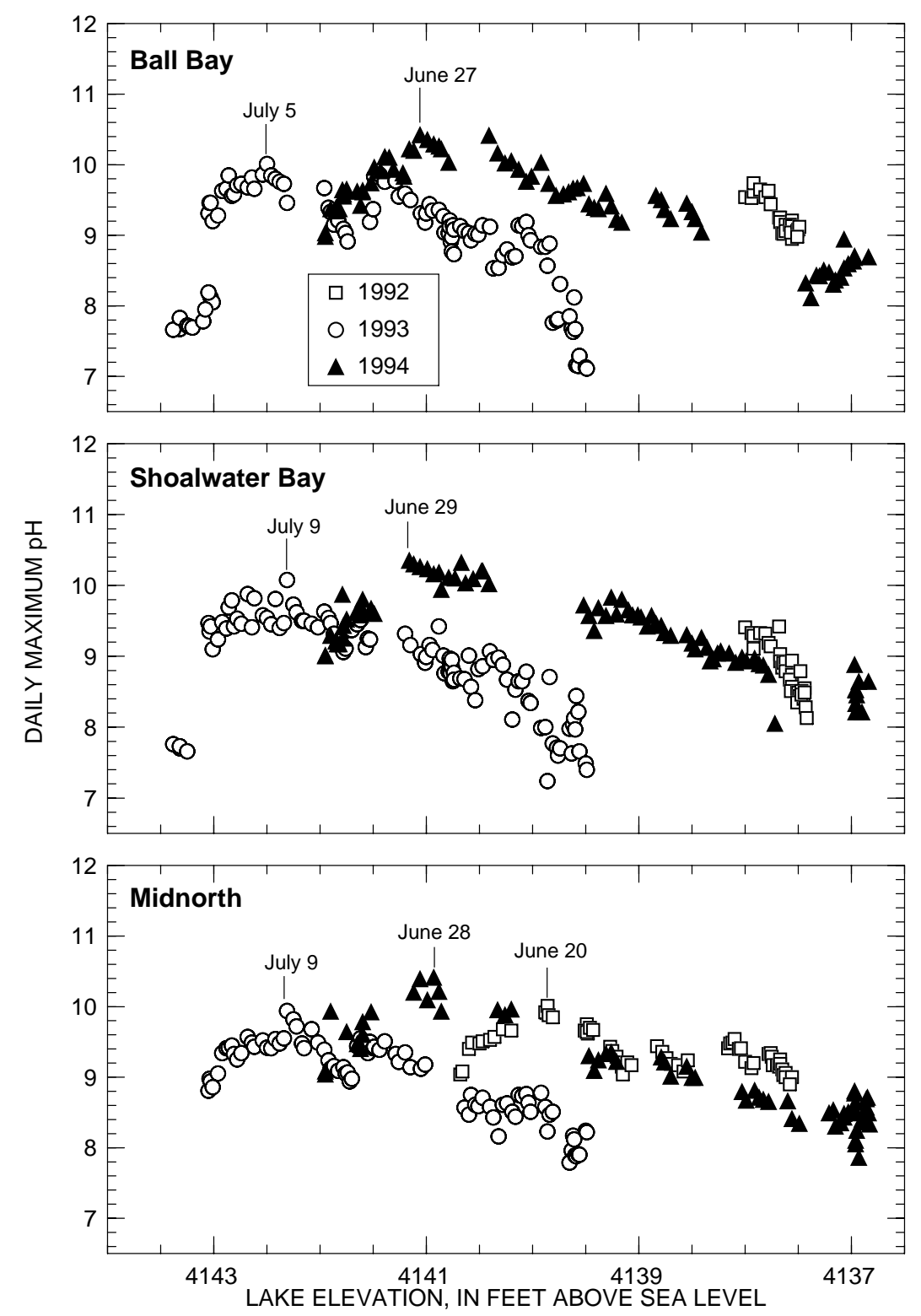

Figure 15. Relation of daily maximum pH from hourly records at Ball Bay, Shoalwater Bay, and Midnorth to lake elevation, Upper Klamath Lake, Oregon, June-September, 1992-94.

increases to a seasonal maximum value, and then decreases.

In figure 15 it is easy to see where large gaps occur in the data record, because lake elevation changes in small increments from day to day (generally much less than one-tenth of a foot). The coverage during 1993 and 1994 at each station is adequate to define the overall pattern in maximum $\mathrm{pH}$ through the season. The coverage during 1992 is adequate to do this only at Midnorth. Even so, the 1993 and 1994 data at three stations provide an opportunity to compare the seasonal maximum in the highest diel $\mathrm{pH}$ and the timing of that maximum between 2 years of differing lake level.

It is difficult to pinpoint the timing of the seasonal maximum precisely because there are data gaps, but the overall pattern of the data suggests that the seasonal maximum occurred around the last week of June in 1992 and 1994, and slightly later, around the first week of July, in 1993. The timing is consistent with the chlorophyll- $a$ data collected during June and July (fig. 11). The $\mathrm{pH}$ data provide evidence in addition to that provided by the chlorophyll- $a$ data that the 
timing of the first bloom (and therefore the worst $\mathrm{pH}$ conditions) is delayed at higher lake elevations. The difference in the timing of the first bloom between 1992 and 1993 resulted in a 3 -week difference in the timing of the occurrence of the highest $\mathrm{pH}$ values; the difference in the timing of the first bloom between 1993 and 1994 resulted in a difference of about a week and a half in the timing of the occurrence of the highest $\mathrm{pH}$ values. An analysis of how a shift of this magnitude in poor water-quality conditions may affect the endangered young-of-the-year suckers over their summertime life stage is beyond the scope of this study.

The seasonal maximum values in both 1993 and 1994 were consistent over the three sites in spite of the fact that Shoalwater Bay and Midnorth had very different chlorophyll- $a$ concentrations (see fig. 11). Those seasonal maxima differ by about $0.4 \mathrm{pH}$ units between 1993 and 1994, with 1994 values being higher than 1993 values, at all three stations. The seasonal maximum in 1992 at Midnorth, the only station for which adequate 1992 data were available, appears to be about the same as in 1993, in spite of the larger bloom in 1992.

The depth-profile data were not designed to measure the highest $\mathrm{pH}$ of the day, but the profile data at Shoalwater Bay and Midnorth show approximately the same maximum $\mathrm{pH}$ values in 1992-1994 (figs. 16 and 17) as the hourly records. Some vertical variation is apparent in the latter part of 1993, such that the 1-m values of $\mathrm{pH}$ during the beginning of August appear to be lower by nearly $1 \mathrm{pH}$ unit than the surface values. Thus, the $\mathrm{pH}$ maxima during 1993 are probably somewhat higher at the surface than it appears in the 1-m records. Otherwise, the depth profiles at individual stations show very little top-to-bottom variation in water column $\mathrm{pH}$. Because $\mathrm{pH}$ is characterized by a relatively small diel cycle and little vertical variation, the highest $\mathrm{pH}$ values at these two sites, as obtained from the hourly records and the profile data, are comparable.

The depth-profile $\mathrm{pH}$ data show relatively little variation among sites, especially compared to the sometimes large site-to-site variation in chlorophyll- $a$. Consistent with the hourly records, the depth-profile data at Shoalwater Bay are not very
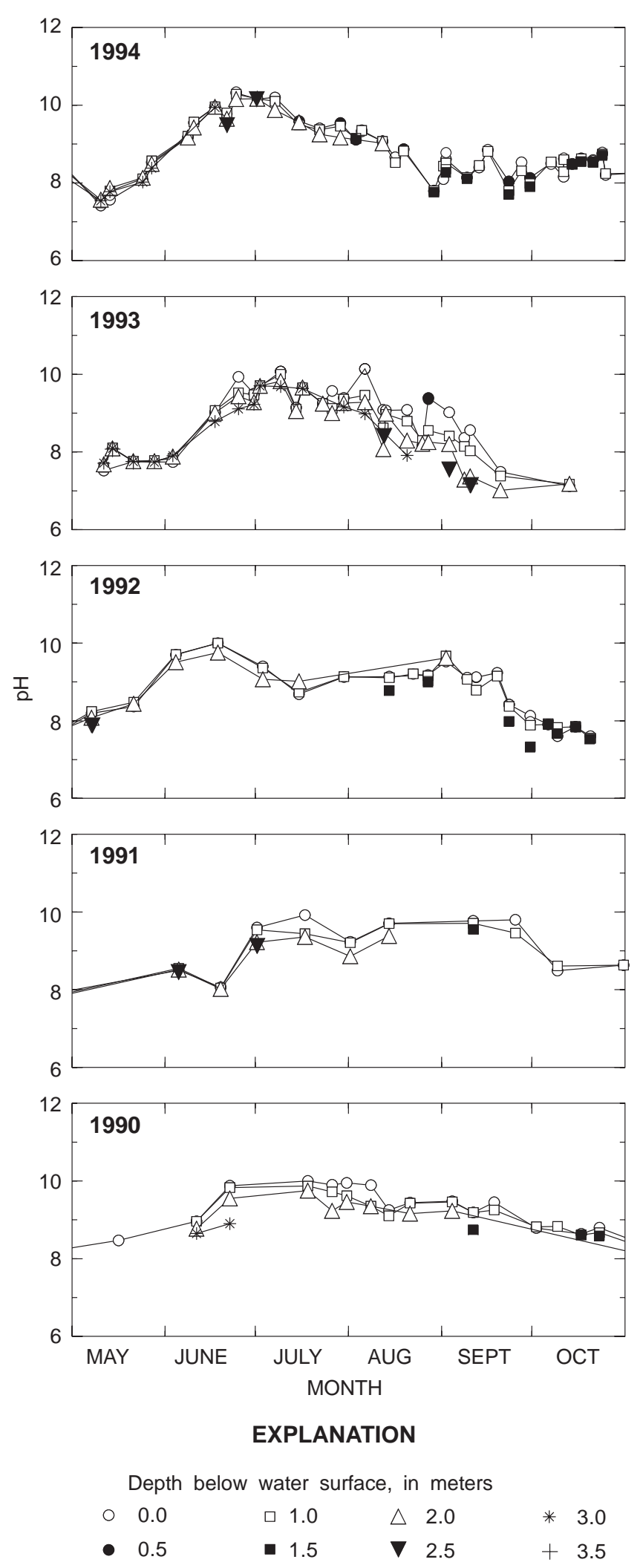

Figure 16. Depth-profile $\mathrm{pH}$ data at Shoalwater Bay, Upper Klamath Lake, Oregon, May-October 1990-94. 

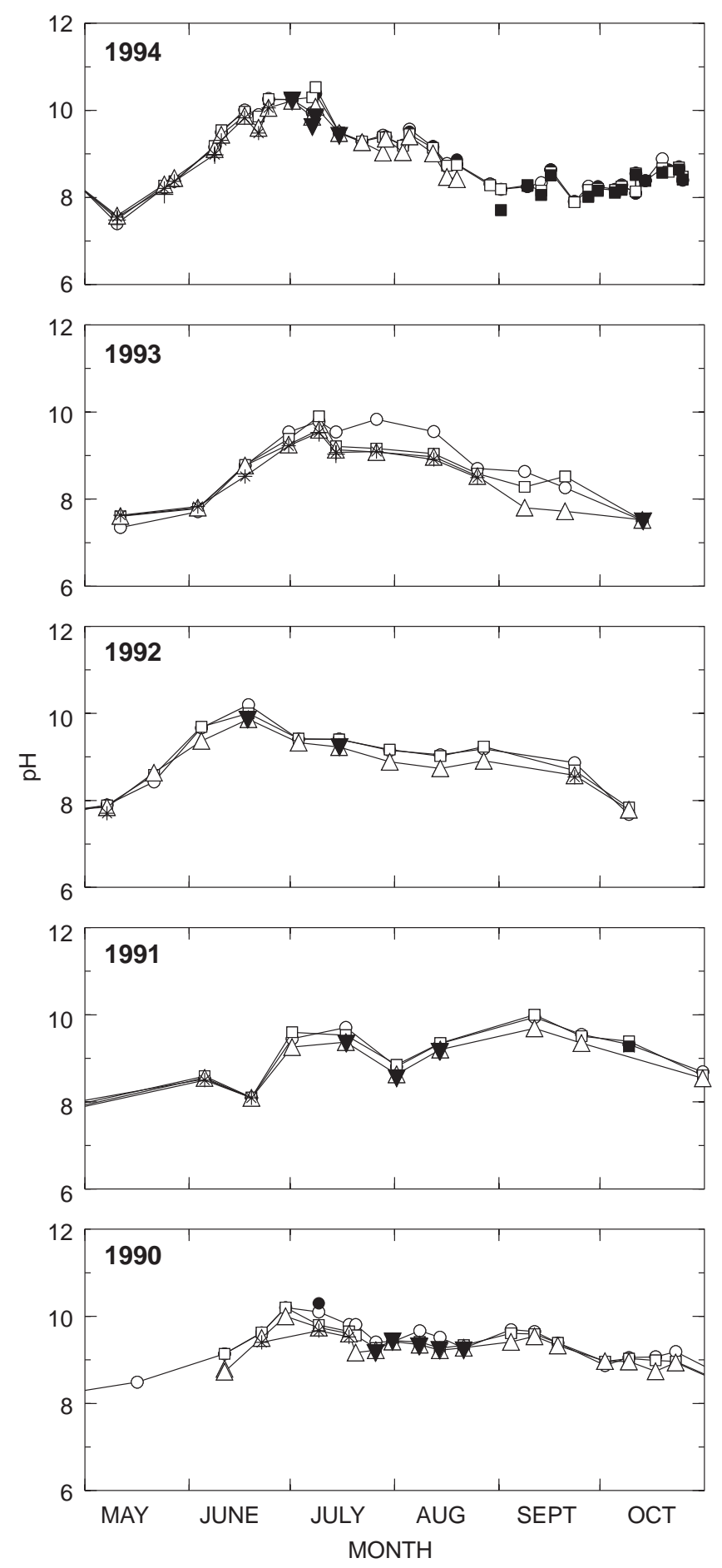

EXPLANATION

Depth below water surface, in meters
○ 0.0
$\square 1.0$
$\triangle 2.0$
* 3.0
- 0.5
- 1.5
$\nabla 2.5$
$+3.5$

Figure 17. Depth-profile $\mathrm{pH}$ data at Midnorth, Upper Klamath Lake, Oregon, May-October 1990-94. different from those at Midnorth, even though the large bloom in 1992 was characterized by much higher chlorophyll- $a$ concentration at Shoalwater Bay.

Considering first the Upper Klamath Lake data, the June distributions show that early in the season the median $\mathrm{pH}$ was higher during 1992 and 1994 than during 1991, 1990, or 1993 (fig. 18). The higher June pH in 1992 and 1994 coincided

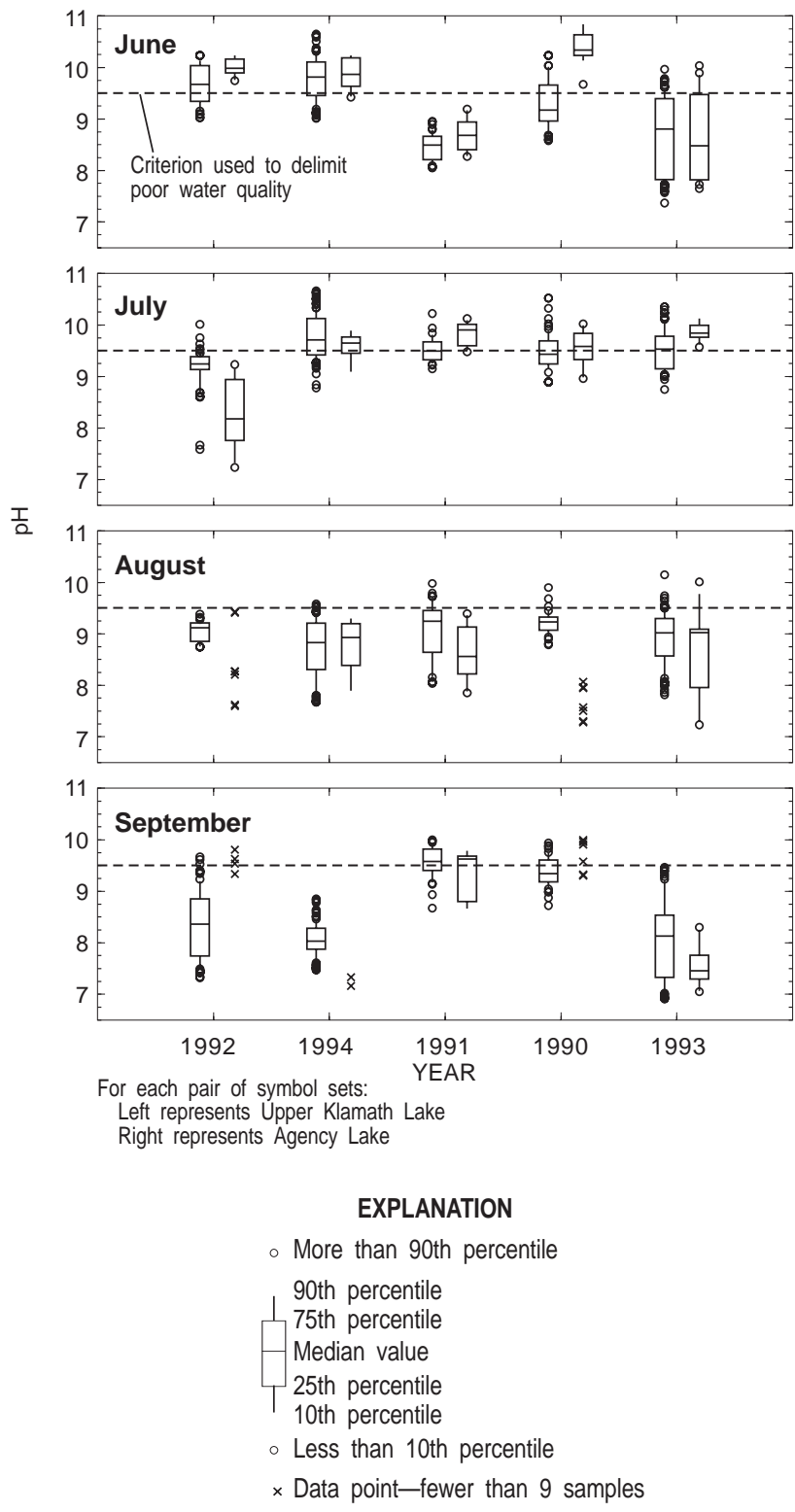

Figure 18. Frequency distributions of lakewide depth-profile $\mathrm{pH}$ data, by month, Upper Klamath and Agency Lakes, Oregon, June-September 1990-94. The years are ranked in order of increasing lake elevation. 
with a higher median chlorophyll- $a$ concentration around the lake (fig. 13). Note, however, that the small positive difference in June $\mathrm{pH}$ distribution between 1992 and 1994 coincided with a large negative difference in June chlorophyll- $a$ between the 2 years; therefore, measures of $\mathrm{pH}$ alone, such as the frequency distribution or the frequency of exceeding a particular value, are not accurate indicators of the difference in magnitude between large blooms. The smaller bloom of 1994 resulted in water quality that was as poor, as indicated by $\mathrm{pH}$, as that which resulted from the larger bloom in 1992. Agency Lake had the highest $\mathrm{pH}$ distribution of all 5 years in June, 1990, coincident with a bloom that was not exceptionally heavy.

In July, median chlorophyll- $a$ values in all 5 years were comparable, and so were median $\mathrm{pH}$ values in all years but 1992. July pH in 1992 had decreased substantially from June (especially in Agency Lake) in comparison to 1994, when July $\mathrm{pH}$ had decreased only slightly from June. In the other 3 years, $\mathrm{pH}$ increased from June and reached maximum values in July. In August, the 1990 and 1991 chlorophyll- $a$ values were higher than in the other years, and by September these 2 years had both a higher chlorophyll- $a$ distribution and a higher $\mathrm{pH}$ distribution.

Because June is a critical month in terms of the first bloom, further examination of the relation between lake level and $\mathrm{pH}$ is focused on that month (fig. 19). An interyear comparison of the earliest June sampling dates reveals a pattern of higher $\mathrm{pH}$ values at lower lake levels in Upper Klamath Lake (compare 6/3/93, 6/11/90, 6/5/91, $6 / 8 / 94$, and 6/3/92). Only in 1992 were there exceedances of $9.5 \mathrm{pH}$ units this early in the season. A comparison of mid-June sampling dates reveals a similar pattern $(6 / 17 / 93,6 / 22 / 90,6 / 19 /$ 91, 6/17/94 and 6/17/92); pH values generally increased with lower lake elevation, with the exception of 6/19/91. Between 6/5/91 and 6/19/91 $\mathrm{pH}$ decreased, coincident with a decrease in chlorophyll-a. In table 11 the mid-June sampling dates are compared on the basis of the frequency of exceeding a $\mathrm{pH}$ of 9.5 .

In Agency Lake, $\mathrm{pH}$ values rose between 6/5/91 and 6/19/91 (fig. 19), coincident with an increase in chlorophyll- $a$ at one Agency Lake site (fig. 14). In 1990, Agency Lake values were con- sistently above $10 \mathrm{pH}$ units, even though chlorophyll- $a$ at the one site sampled in that year was moderate in comparison with 1992 and 1994. As was discussed previously for Upper Klamath Lake, there is not necessarily a correspondence between the strength of a bloom (as measured by chlorophyll-a) and coincident $\mathrm{pH}$. In Agency Lake, 2 years of similar lake level (1990 and 1991) had widely differing June water quality as defined by $\mathrm{pH}$.

The relation between interannual differences in $\mathrm{pH}$ and interannual differences in lake level is not simple; nonetheless, the 2 years at the extremes in lake level, 1992 and 1993, show a marked contrast in the June data. Consistent with the pattern in chlorophyll- $a$, pH in 1992 began to increase earlier and reached higher values in early June than did pH in any other year. In 1993, pH rose more slowly and was at a lower value early in June than it was in any other year. In 1994, pH rose somewhat more slowly than in 1992 (compare $6 / 8 / 94$ with $6 / 3 / 92$ in fig. 19), but reached similar maximum values later in June. In 1990, pH rose somewhat later than in 1994 and somewhat earlier than in 1993 (compare 6/8/94, 6/11/90, and 6/3/ 93 ). Based on only two sites that were sampled on 6/29/90, pH values in Upper Klamath Lake were probably comparable to those reached in 1992 about 10 days earlier. In $1991 \mathrm{pH}$ declined between the two June sampling dates, coincident with a decline in chlorophyll- $a$. In Agency Lake, the comparison between 1992 and 1993 is similar to that in Upper Klamath Lake, but 1990 and 1994 measurements were as high or higher than in 1992.

The distributions of the depth-profile $\mathrm{pH}$ data are not consistent with Hypothesis 4 in the broadest sense, but are consistent with this more narrowly defined hypothesis:

\section{Hypothesis 5: Year-to-year differences in the June frequency of $\mathrm{pH}$ values greater than 9.5 are related to interannual differences in lake level, such that the June frequency is lower at higher June lake level.}

The fact that the data are consistent with this hypothesis is directly related to the fact that the chlorophyll- $a$ data are consistent with Hypothesis 2. The earlier rise in chlorophyll- $a$ at lower lake elevations prompted an earlier rise in $\mathrm{pH}$ around 


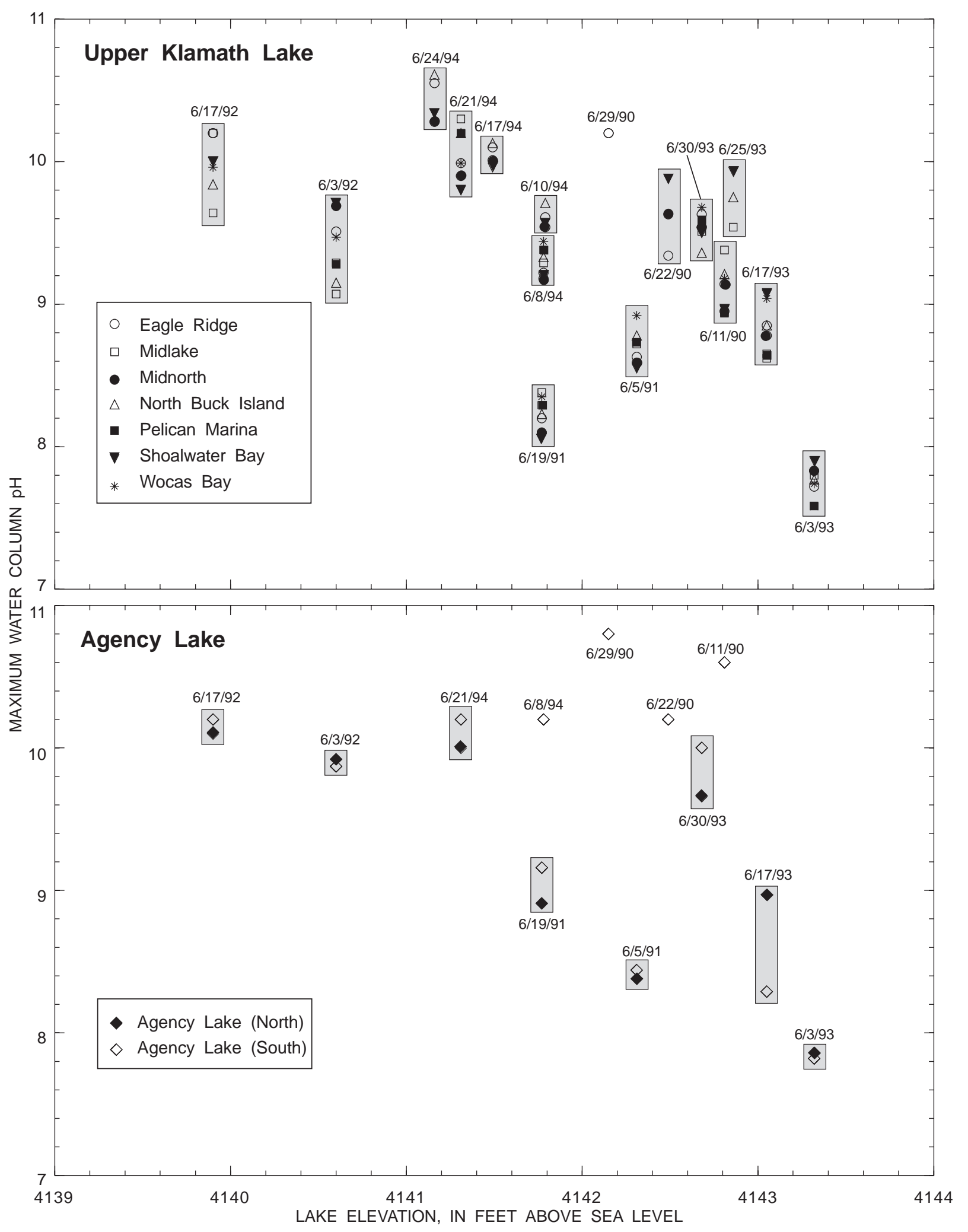

Figure 19. Relation of maximum $\mathrm{pH}$ from depth-profile data at selected sites to lake elevation, Upper Klamath and Agency Lakes, Oregon, June 1990-94. The corresponding sampling date is noted next to each group of data points. 
Table 11. Frequency of June pH values greater than 9.5, Upper Klamath Lake, Oregon, 1990-94

\begin{tabular}{lccccc}
\hline & $\mathbf{0 6 / 2 2 / 9 0}$ & $\mathbf{0 6 / 1 9 / 9 1}$ & $\mathbf{0 6 / 1 7 / 9 2}$ & $\mathbf{0 6 / 1 7 / 9 3}$ & $\mathbf{0 6 / 1 7 / 9 4}$ \\
\hline Total number of $\mathrm{pH}$ values & 16 & 27 & 26 & 34 & 17 \\
Total number of $\mathrm{pH}$ values greater than 9.5 & 5 & 0 & 25 & 0 & 17 \\
Percentage of $\mathrm{pH}$ values greater than 9.5 & 31 & 0 & 96 & 0 & 100 \\
\hline
\end{tabular}

the lake. The delay in the occurrence of high $\mathrm{pH}$ values during high- lake-level years was 2 to 3 weeks. This could be important if June represents a particularly critical time in the life cycle of the endangered suckers. Lake level had little apparent influence, however, on the maximum $\mathrm{pH}$ values eventually reached-the distributions of the profile pH values during July in 1990, 1991, and 1993 (median values 9.41, 9.48, and 9.51, respectively; 90th percentile values $9.87,9.79$, and 10.07 , respectively) were not much different from the June distributions in 1992 and 1994 (median values 9.64 and 9.78, respectively; 90th percentile values 10.1 and 10.26 , respectively; fig. 18).

\section{Dissolved Oxygen}

A general statement of the hypothesis relating dissolved oxygen concentration to lake level is as follows:

Hypothesis 6: Year-to-year differences in the frequency of occurrence of dissolved oxygen concentrations less than $4 \mathrm{mg} / \mathrm{L}$ are related to year-to-year differences in lake level, such that the frequency is lower at higher lake level.

Dissolved oxygen concentration fluctuates over the day and often reaches a daily minimum value just before the sun comes up and photosynthetic activity begins. As was the case for the diel maximum in $\mathrm{pH}$, therefore, the diel minimum in dissolved oxygen concentration was only recorded at 1-m depth and at the three sites-Midnorth, Shoalwater Bay, and Ball Bay-where fixed-depth Hydrolabs were deployed. The hourly Hydrolab records from the three moored instruments were screened for minimum dissolved oxygen values over the day. Days with inadequate coverage (less than 20 of 24 hours) were dropped from the analysis. The daily minima were plotted against both lake elevation and time for the period June-September. The diel minima have large day-to-day variability but a downward trend as lake level decreases through the season is evident (fig. 20). This trend is undoubtedly the result of a mix of processes, some of which depend directly on lake level, and some of which would cause dissolved oxygen concentration to decrease through the season even if lake level were not dropping simultaneously.

A seasonal effect is imposed by the cycle of algal growth, as photosynthesizing cells produce dissolved oxygen and senescing cells consume it. Seasonal variation is also imposed by the effect of water temperature on the saturation concentration $\left(\mathrm{C}_{\mathrm{s}}\right)$ of dissolved oxygen. The change in the saturation concentration from May to August could be as much as $2 \mathrm{mg} / \mathrm{L}\left[\mathrm{C}_{\mathrm{s}}=10.0 \mathrm{mg} / \mathrm{L}\right.$ at $15^{\circ} \mathrm{C}$ and $\mathrm{C}_{\mathrm{s}}=8.2 \mathrm{mg} / \mathrm{L}$ at $25^{\circ} \mathrm{C}$, using equation 1 in Bowie and others (1985, p. 91).

The decline in lake level over the summer could impose an additional seasonal pattern. The rate of oxygen depletion due to sediment oxygen demand is inversely proportional to the depth of the water column; therefore, simple water volume considerations dictate that the same areal rate of sediment oxygen demand will deplete oxygen faster at lower lake elevations. An increased frequency of sediment resuspension at lower lake elevation has implications for dissolved oxygen concentration, because it is reasonable to expect that resuspended sediments carry a significant chemical and biological oxygen demand. Increased oxygen demand at lower lake levels could be compensated to some extent by increased reaeration if the frequency at which the lake mixes from top to bottom also increases.

The hourly records of dissolved oxygen concentration are not sufficient to quantitatively separate these components. However, if oxygendemanding processes that depend in large part on 

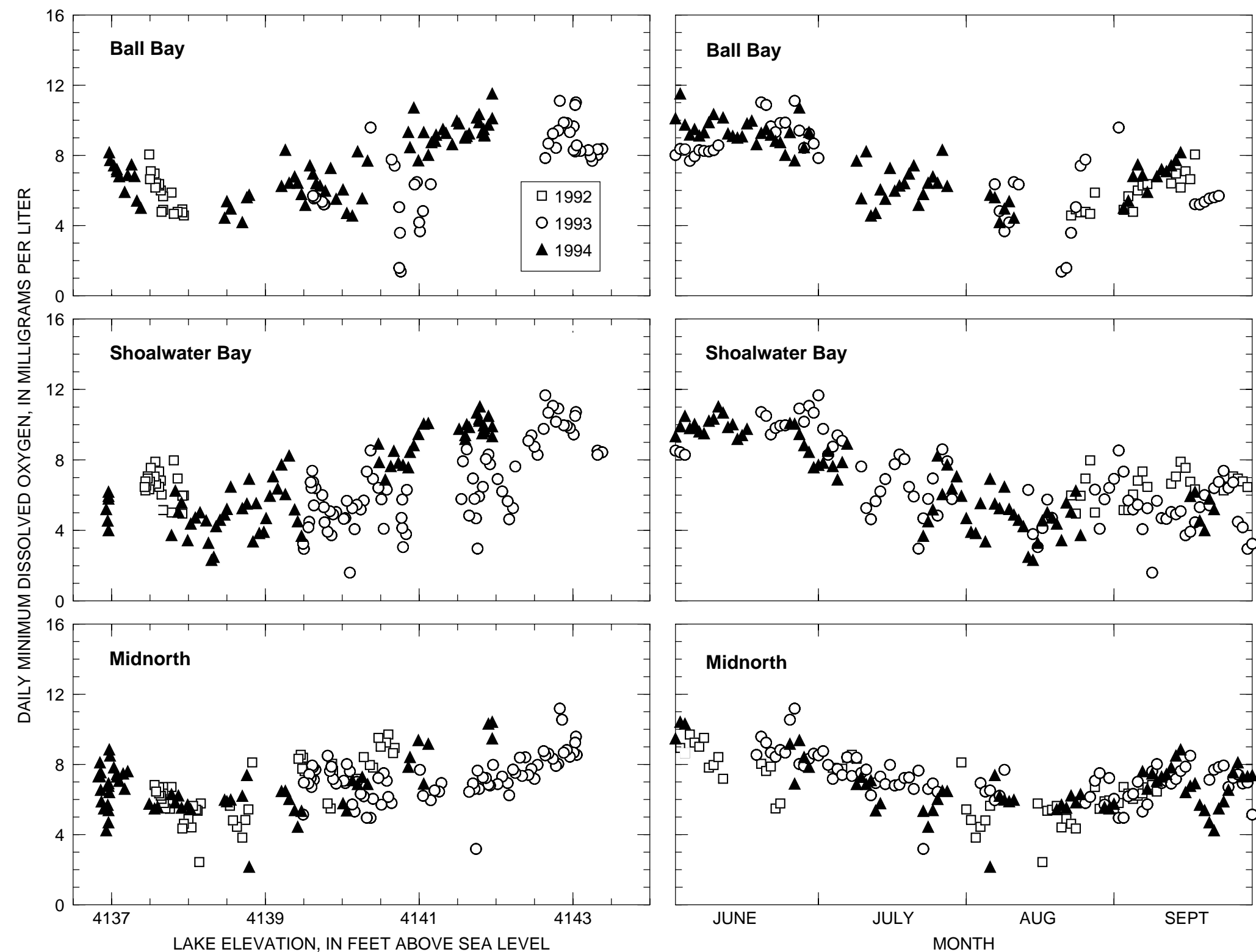

Figure 20. Relation of daily minimum dissolved oxygen concentration from hourly records to lake elevation, Upper Klamath Lake, Oregon, June-September 1992-94. 
lake level were the primary controlling processes on the concentration of dissolved oxygen, then similar lake levels should have resulted in similar dissolved oxygen concentration each year, regardless of when those lake levels occurred. The 1993 concentrations at Shoalwater Bay, however, dipped below $4 \mathrm{mg} / \mathrm{L}$ by about the third week in July, even though lake elevation was still above $4141.5 \mathrm{ft}$. The 1994 concentrations dipped below $4 \mathrm{mg} / \mathrm{L}$ at about the same time, but lake elevation in that year was already down to $4139.5 \mathrm{ft}$. The overall minimum values attained during the season were comparable between 1993 and 1994, but they occurred at very different lake levels. Furthermore, 1994 concentrations were consistently higher at Shoalwater Bay than 1993 concentrations from 4142.0 to $4141.5 \mathrm{ft}$ and again from 4141.0 to $4140.5 \mathrm{ft}$ (fig. 20). There is some evidence of higher 1994 concentrations in the same lake level ranges at Ball Bay and Midnorth, but there are fewer data values to compare. It also appears in some of the data that dissolved oxygen concentration stopped its downward trend at the lowest lake levels and even increased somewhat as the elevation dropped below about $4138 \mathrm{ft}$ (see, in particular, 1992 and 1994 data at Ball Bay and 1992 and 1993 data at Midnorth). This increase in concentration at the lowest lake levels suggests that increased oxygen demand, whether it be sediment, chemical, or biological, at lower lake levels is not the primary controlling factor in determining dissolved oxygen concentration at those low lake levels.

The placement of the instruments adds an additional complication, but a careful examination of that placement and information on the depth of the water column revealed no systematic concentration differences that could be explained by instrument placement. For example, placement at 1 $\mathrm{m}$ from the surface would have put the instrument about $1 \mathrm{~m}$ closer to the bottom at Shoalwater Bay during June and July in 1992 than in 1993, but 1992 concentrations are not systematically lower than those in 1993. Similarly, the instrument would have been over $1 \mathrm{~m}$ farther from the bottom during August and September in 1993 than it was in 1994, but again, the concentrations do not indicate more bottom influence in the 1994 data.

The dissolved oxygen data used in this study are not sufficient to distinguish the relative impor- tance of the various processes and the possible artifacts of data collection that determined the measured concentration. Because similar lake levels resulted in quite different dissolved oxygen concentrations, however, it is most likely that temporal trends were determined primarily (but not exclusively) by seasonal factors, such as the algal growth cycle and water temperature control of saturation. Nonetheless, the extent to which oxygen demands that are enhanced by lower lake levels superimpose on other seasonal effects and influence the lower extremes of the distribution of dissolved oxygen concentration cannot be quantified with this dataset. The effect of lake level on sediment oxygen demand and resuspended chemical and biological oxygen demand may be important when water quality in the lake is already marginal for aquatic life. In a situation where dissolved oxygen conditions are marginal for fish at a relatively high lake level, the possibility that, at a lower lake level, concentrations could be lowered only slightly but enough to threaten fish survival cannot be ruled out.

The hourly records were representative only of conditions in the upper part of the water column; conditions nearer the bottom that were more influenced by sediment oxygen demand could differ from those at $1 \mathrm{~m}$, sometimes markedly. The depth-profile data at Shoalwater Bay and Midnorth confirm that there was, at times, considerable variability with depth (figs. 21 and 22). In spite of this variability, a dissolved oxygen concentration less than $4 \mathrm{mg} / \mathrm{L}$ was measured on only two sampling dates-8/16/94 and 7/14/92 - at $1 \mathrm{~m}$ in the profile data at Shoalwater Bay (fig. 21). The hourly data (fig. 20) show that the diel minimum at $1 \mathrm{~m}$ dips below $4 \mathrm{mg} / \mathrm{L}$ more frequently than indicated in the profile data, which is further evidence that the profile data do not necessarily capture the lowest dissolved oxygen conditions of the day. On many days throughout the summer, dissolved oxygen concentrations may well be lower, not only at 1-m depth, but throughout the water column, than is indicated by the profile data. Therefore, calculations of the frequency of dissolved oxygen concentration less than $4 \mathrm{mg} / \mathrm{L}$ based on these data may underestimate the occurrence of those conditions.

Frequency distributions of the dissolved oxygen concentration for 1990-94 are shown in figure 23 . The central tendency of the distributions 

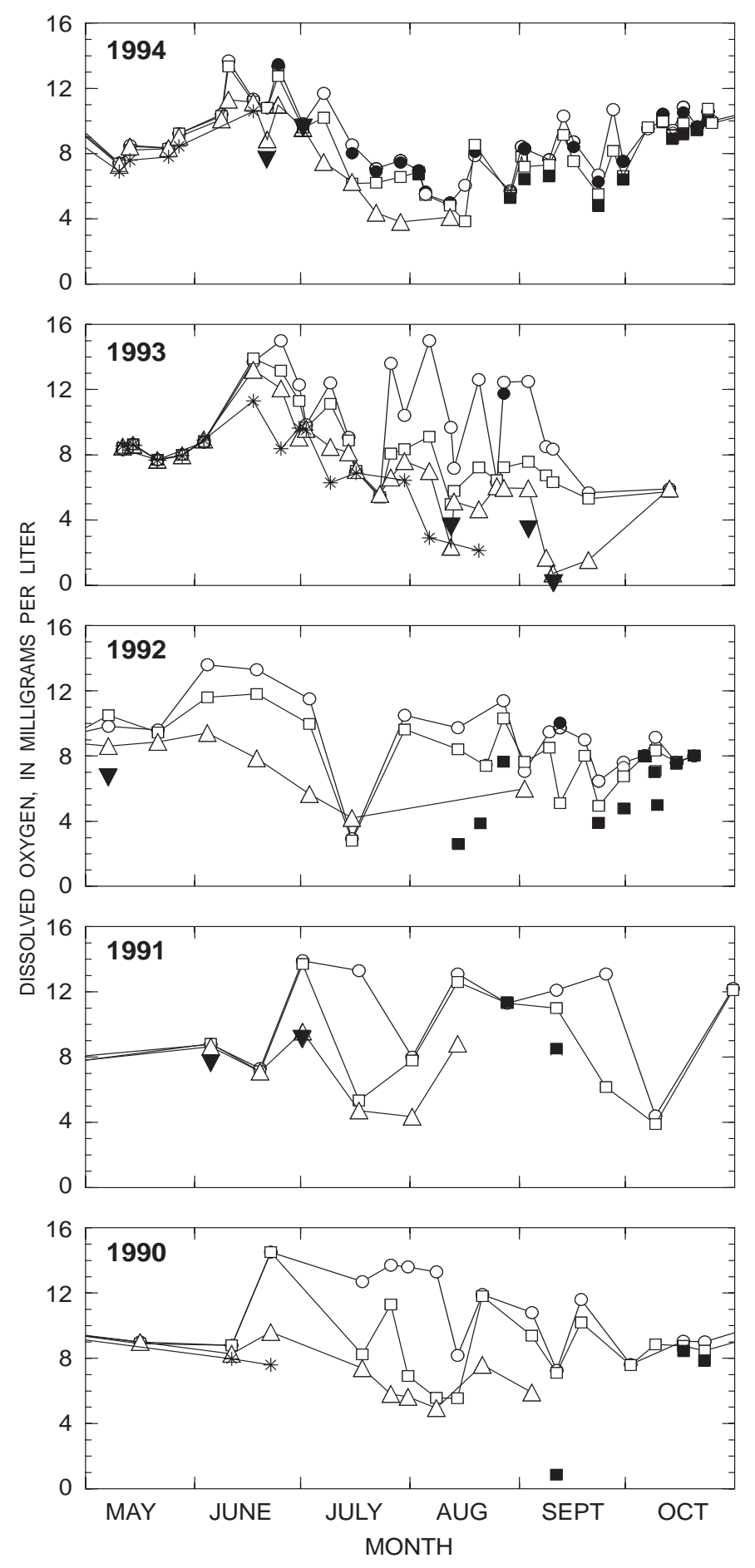

EXPLANATION

Depth below water surface, in meters
○ 0.0
ㅁ 1.0
$\triangle 2.0$
* 3.0
- 0.5
- 1.5
$\nabla 2.5$
$+3.5$

Figure 21. Dissolved oxygen depth-profile data at Shoalwater Bay, Upper Klamath Lake, Oregon, May-October 1990-94.
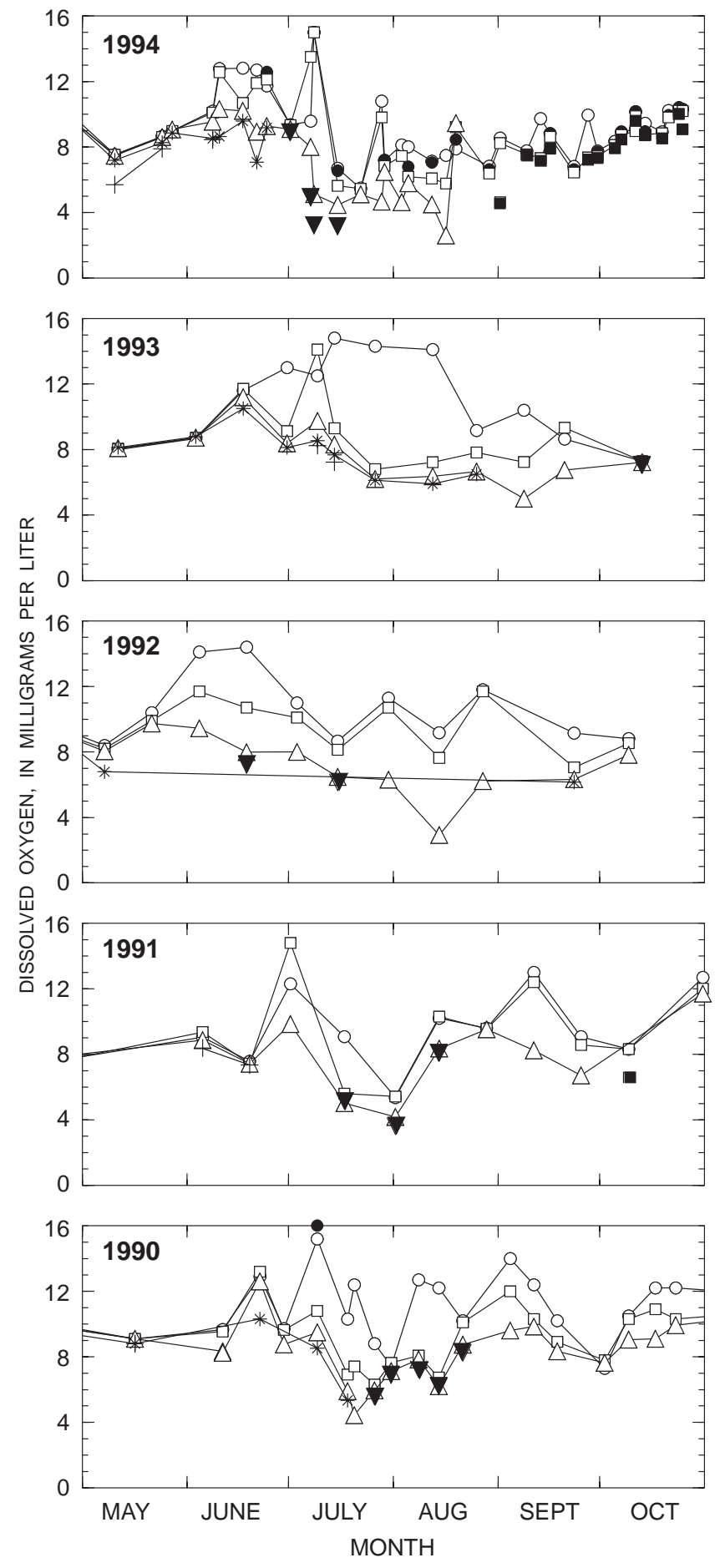

EXPLANATION

Depth below water surface, in meters
○ 0.0
$\square 1.0$
$\triangle 2.0$
* 3.0
- 0.5
- 1.5
$\nabla 2.5$
$+3.5$

Figure 22. Dissolved oxygen depth-profile data at Midnorth, Upper Klamath Lake, Oregon, May-October 1990-94. 


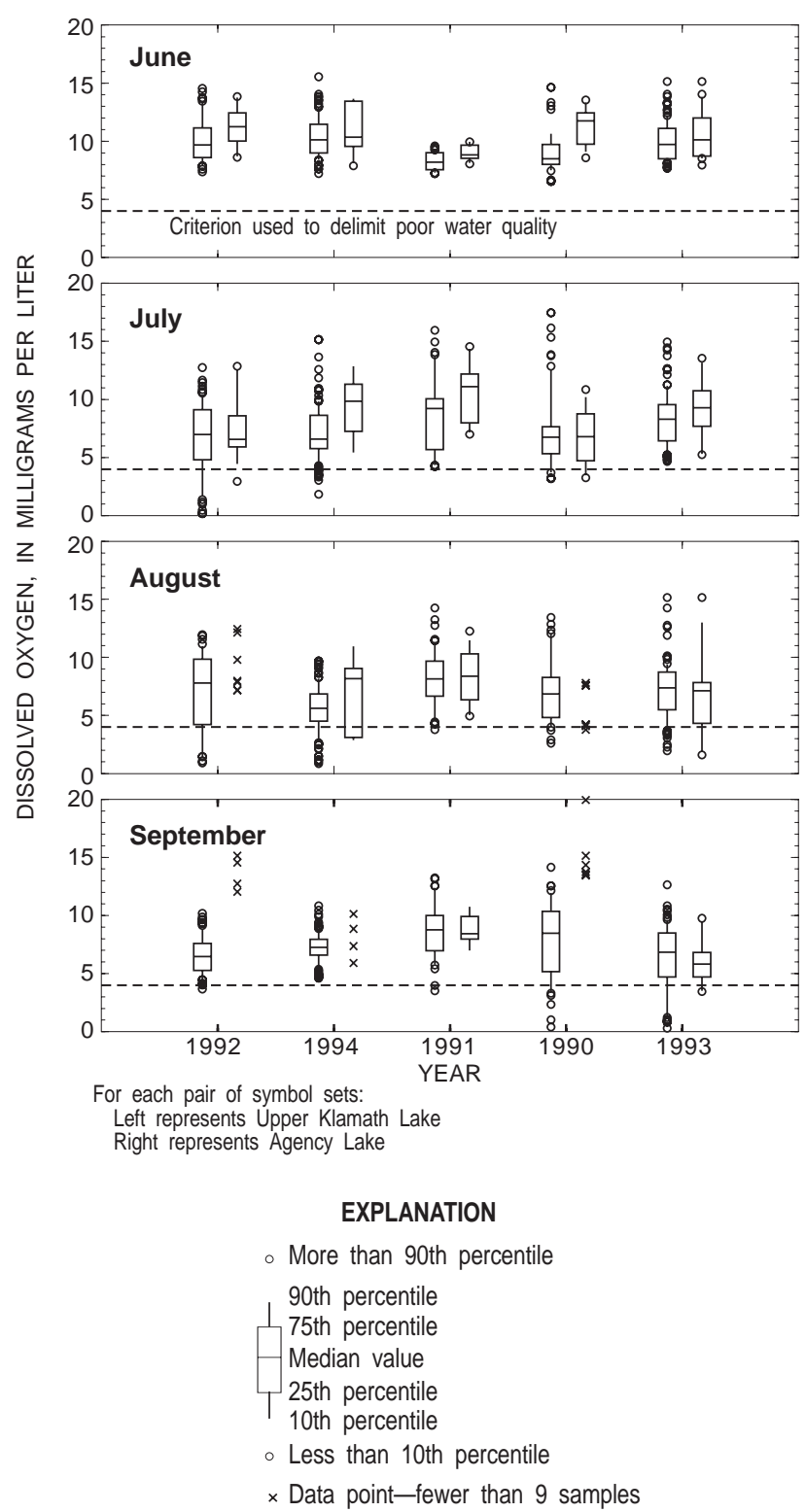

Figure 23. Frequency distributions of lakewide depthprofile dissolved oxygen data, by month, Upper Klamath and Agency Lakes, Oregon, June-September, 1990-94.

The years are ranked in order of increasing lake elevation.

varies little compared to the large range in values within a month. For example, in July, August, and September in Upper Klamath Lake, the range in the data in every year encompasses the 25 th and 75 th percentile of the data in every other year. This is another illustration of the fact that year-to-year variability in dissolved oxygen concentration tends to be secondary to week-to-week, site-to-site, and top-to-bottom variability. The central tendency of the data, however, may not be their most important feature because the majority of values is always greater than the $4 \mathrm{mg} / \mathrm{L}$ crite- rion used in this analysis to delimit poor water-quality conditions. More important are the less frequent but very low measurements of dissolved oxygen concentration that can be harmful to fish over short exposure times.

In July, the greatest frequency of values less than $4 \mathrm{mg} / \mathrm{L}$ occurred in 1990 and 1992 (12\%) and in 1994 (8\%) (table 12). Dissolved oxygen concentrations in July 1991 and 1993 were always greater than $4 \mathrm{mg} / \mathrm{L}$ (fig. 23). The 1994 distributions are somewhat biased, compared with the other years, by the deeper sampling at the Eagle Ridge site (fig. 7). If the depths at Eagle Ridge are cut off at 6 $\mathrm{m}$ in order to correspond to the deepest sampling at that site in other years, then the frequency of measurements of dissolved oxygen less than $4 \mathrm{mg} / \mathrm{L}$ is $5 \%$ instead of $8 \%$, although the lowest extent of the distribution is unchanged at $1.7 \mathrm{mg} / \mathrm{L}$ (table 12).

Dissolved oxygen concentration less than 4 $\mathrm{mg} / \mathrm{L}$ was measured as early as July in 1992, 1994, and 1990 (fig. 23). Particularly in 1992, concentrations near zero were measured, and $10 \%$ of the data were below $2 \mathrm{mg} / \mathrm{L}$ in Upper Klamath Lake; the year characterized by the earliest, heaviest bloom was also characterized by the earliest onset of dissolved oxygen concentration less than $4 \mathrm{mg}$ / $\mathrm{L}$ and the lowest July dissolved oxygen concentrations. The year 1994 was characterized by a slightly later and lighter bloom and had less severe dissolved oxygen concentrations in July. The July 1990 dissolved oxygen distribution was comparable to that in 1992 in the frequency of dissolved oxygen concentrations less than $4 \mathrm{mg} / \mathrm{L}$ (table 12), although the lowest value was $3.2 \mathrm{mg} / \mathrm{L}$, not as low as in either 1992 or 1994 . The years 1991 and 1993 were characterized by relatively late, light blooms and no measurements of concentrations less than $4 \mathrm{mg} / \mathrm{L}$ were made as early as July in those years.

There may be a correspondence between the strength and timing of the first algal bloom and the occurrence of low dissolved oxygen concentration; earlier, heavier blooms could result in an earlier accumulation of oxygen-demanding material in the water column or at the sediment/water interface and, therefore, an earlier occurrence of localized, low dissolved oxygen concentration. The intercomparison of 1991, 1992, 1993, and 1994 is con- 
Table 12. Frequency summary of July dissolved oxygen values less than 4 milligrams per liter, Upper Klamath Lake, Oregon, 1990-94

\begin{tabular}{lcrrrrr}
\hline & $\mathbf{1 9 9 0}$ & $\mathbf{1 9 9 1}$ & $\mathbf{1 9 9 2}$ & $\mathbf{1 9 9 3}$ & $\mathbf{1 9 9 4}$ & $\mathbf{1 9 9 4}$ \\
\hline Total number of July values & 93 & 54 & 89 & 126 & 171 & 149 \\
Total number of July values less than 4 milligrams per liter & 11 & 0 & 11 & 0 & 14 & 7 \\
Percentage of July values less than 4 milligrams per liter & $12 \%$ & $0 \%$ & $12 \%$ & $0 \%$ & $8 \%$ & $5 \%$ \\
\hline
\end{tabular}

${ }^{\top}$ Values in this column were calculated from a dataset in which data collected at depths greater than 6 meters at Eagle Ridge were removed

sistent with this interpretation. The occurrence of values less than $4 \mathrm{mg} / \mathrm{L}$ in July 1990 may be another indication that June chlorophyll- $a$ in that year was underestimated.

In August, very low dissolved oxygen concentrations were observed in every year (but only 1 value in 1991, fig. 23). By September, only a few measurements in 1992 and none in 1994 were below $4 \mathrm{mg} / \mathrm{L}$; however, concentrations near zero were measured in 1990 and 1993. Conditions in 1991 were less severe, possibly because a late-season bloom in that year acted as a photosynthetic source of oxygen to the water column. Near the end of the season, in September, the 2 highestlake-level years, 1990 and 1993, had the lowest extremes in dissolved oxygen concentration. The best overall year for dissolved oxygen concentration was 1991, in which a large bloom early in the season (June/July) never materialized, but in which there was a moderate bloom at the end of August and, at some sites, substantial algal growth through September.

Given that there appears to have been significant seasonal control of dissolved oxygen concentration by the algal growth cycle, any influence that lake level had on the timing of the first bloom could potentially have influenced the timing of the first occurrences of low dissolved oxygen concentration. Because July was a transitional month in which low dissolved oxygen concentrations were measured in some years but not in others, this month was singled out for further consideration. Consideration of July by itself is not meant to de-emphasize the occurrence of poor dissolved oxygen conditions later in the season, but it is reasonable if it can be determined that young-ofthe-year fish are more susceptible to stressful conditions in July than in August.
The profile minimum dissolved oxygen concentration on each July sampling date was plotted against the corresponding lake elevation at seven Upper Klamath Lake sites and two Agency Lake sites (fig. 24). Dissolved oxygen does not progress systematically through the month of July as did chlorophyll- $a$ and $\mathrm{pH}$ through June, but rather differs from site to site and from date to date with no consistent pattern. As a result, the effect of inconsistencies in the sampling pattern on the overall distributions is very difficult to assess. These inconsistencies include (1) measurements were collected in July 1990 only once at four sites in Upper Klamath Lake and not at all at one site in Agency Lake, (2) measurements were collected, at most, twice in July 1991, and at four stations only once, and (3) 1993 and 1994 measurements were collected from one to seven times, depending on the site. Only in 1992 was sampling done on the same three dates consistently at each site. Given these inconsistencies, and that dissolved oxygen concentrations were highly variable, analyses based on its distribution, such as the frequency data in table 12, may be misleading and probably are not a valid basis for interannual comparisons.

There are conclusions, however, that seem justifiable in spite of the inconsistencies in sampling. One is water quality in July 1992 was particularly poor in terms of dissolved oxygen concentration. That year was notable not just for the number of measurements of dissolved oxygen concentration less than $4 \mathrm{mg} / \mathrm{L}$, but also for the fact that only in this year was low dissolved oxygen concentration measured near the surface in July. At Wocas Bay on 7/2/92 concentrations of 0.32 and $0.84 \mathrm{mg} / \mathrm{L}$ were measured at $0-$ and $1-\mathrm{m}$ depth, respectively, and 12 days later concentrations of 2.9 and $2.8 \mathrm{mg} / \mathrm{L}$ were measured at 0 - and 1-m depth respectively at Shoalwater Bay. In addition, the lower limit of dissolved oxygen concen- 


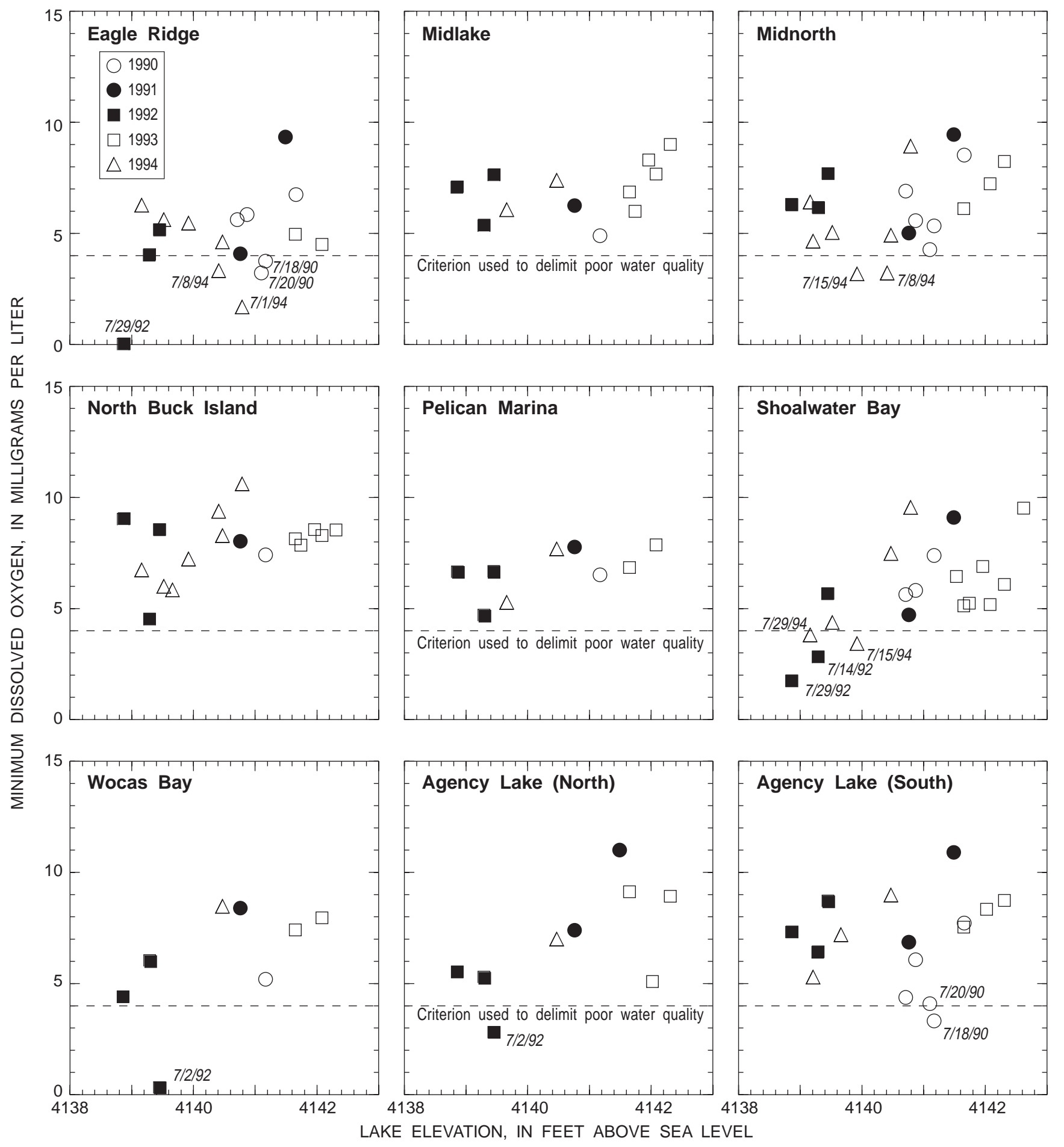

Figure 24. Relation of minimum dissolved oxygen concentration from depth-profile data at selected sites to lake elevation, Upper Klamath and Agency Lakes, Oregon, July 1990-94. The corresponding sampling date is noted next to data points falling below the criterion for poor water quality. 
tration in July 1992 was low in comparison to all of the other years (fig. 23). The 10th percentile was $1.5 \mathrm{mg} / \mathrm{L}$, which was lower than the lowest value measured in any other year. For comparison, in July 1990 the same number and percentage of measurements less than $4 \mathrm{mg} / \mathrm{L}$ were recorded, but none of those were made at a depth of $1 \mathrm{~m}$ or less, and the lowest value was $3.3 \mathrm{mg} / \mathrm{L}$. Therefore, 1992 is distinguished from the other years not just by the number of July measurements less than 4 $\mathrm{mg} / \mathrm{L}$ but also by their severity and location in the water column.

There are also enough data to conclude that some sites are probably more susceptible to extreme dissolved oxygen conditions than others. Both the hourly records (fig. 20) and the profile data (figs. 21 and 22), for example, suggest that concentrations less than $4 \mathrm{mg} / \mathrm{L}$ at $1 \mathrm{~m}$ are more likely to occur at Shoalwater Bay than at Midnorth.

In general, the dissolved oxygen data are not consistent with a relation between water quality and lake level, with the exception of the year of lowest lake level, 1992. In that year, some profile measurements of exceptionally low dissolved oxygen concentration were recorded as early as the first few days of July. In that same year, a particularly early, heavy bloom generated large quantities of algae. To the extent that early spring lake level played a role in determining the timing and magnitude of that bloom, it may also have played a role in determining July dissolved oxygen concentrations. Low July lake level may have made conditions worse by concentrating sediment oxygen demand over a smaller water column, or by increasing the frequency of mixing events that resuspended sediment that caused chemical and biological oxygen demand. As was noted in the discussion of the hourly data (fig. 20), however, there is no way to quantitatively assess the degree to which those oxygen demands, enhanced by low lake level, influenced the low extremes of the concentration distribution in this dataset.

\section{Total Phosphorus}

Phosphorus is not directly harmful to fish; rather, high concentrations of phosphorus can potentially lead to heavy algal blooms, high $\mathrm{pH}$ generated through photosynthesis, and low dissolved oxygen concentration when the bloom starts to decline. A general statement of the hypothesis relating total phosphorus to lake level is as follows:

\section{Hypothesis 7: Year-to-year differences in phosphorus concentration are related to year-to-year differences in lake level, such that phosphorus concentration is lower at higher lake levels.}

Phosphorus concentration is, at times, highly variable around the lake (fig. 25). Particularly notable is the occasionally large difference between the sites located in Agency Lake and those in Upper Klamath Lake (especially in 1993 and 1994), indicating that the loading to these two water bodies can be quite different. The magnitude and timing of the seasonal maximum concentrations of total phosphorus varied from year to year, so the interannual comparison changed depending on the time period considered.

In figure 26, the total phosphorus frequency distributions are shown by month and year. In June, and to some extent in July, there was a distinction between 1992 and the rest of the years in Upper Klamath Lake (in Agency Lake the distinction is between both 1992 and 1994 and the rest of the years). June 1992 concentrations in Upper Klamath Lake were much higher (approaching 500 $\mu \mathrm{g} / \mathrm{L}$ at the upper extreme) than in June of any other year. In Agency Lake, both 1992 and 1994 concentrations were high in comparison to those in the remaining 3 years. In July, concentrations in all years increased from June levels in Upper Klamath Lake, but 1992 continued to have the highest concentration. In Agency Lake, 1994 concentrations were higher than in all other years (one measurement as high as $700 \mu \mathrm{g} / \mathrm{L}$ ), and were higher than any measurements in Upper Klamath Lake.

The 2 years that sustained heavy blooms through the season, 1990 and 1991, had distinctly higher total phosphorus concentrations starting in August and persisting through September. August 1992 concentrations were down from July values, whereas 1991 and 1990 concentrations were up from July values. Examination of the progression of the total phosphorus distributions in Upper Klamath Lake from month to month shows that total phosphorus remained fairly steady or fell through 

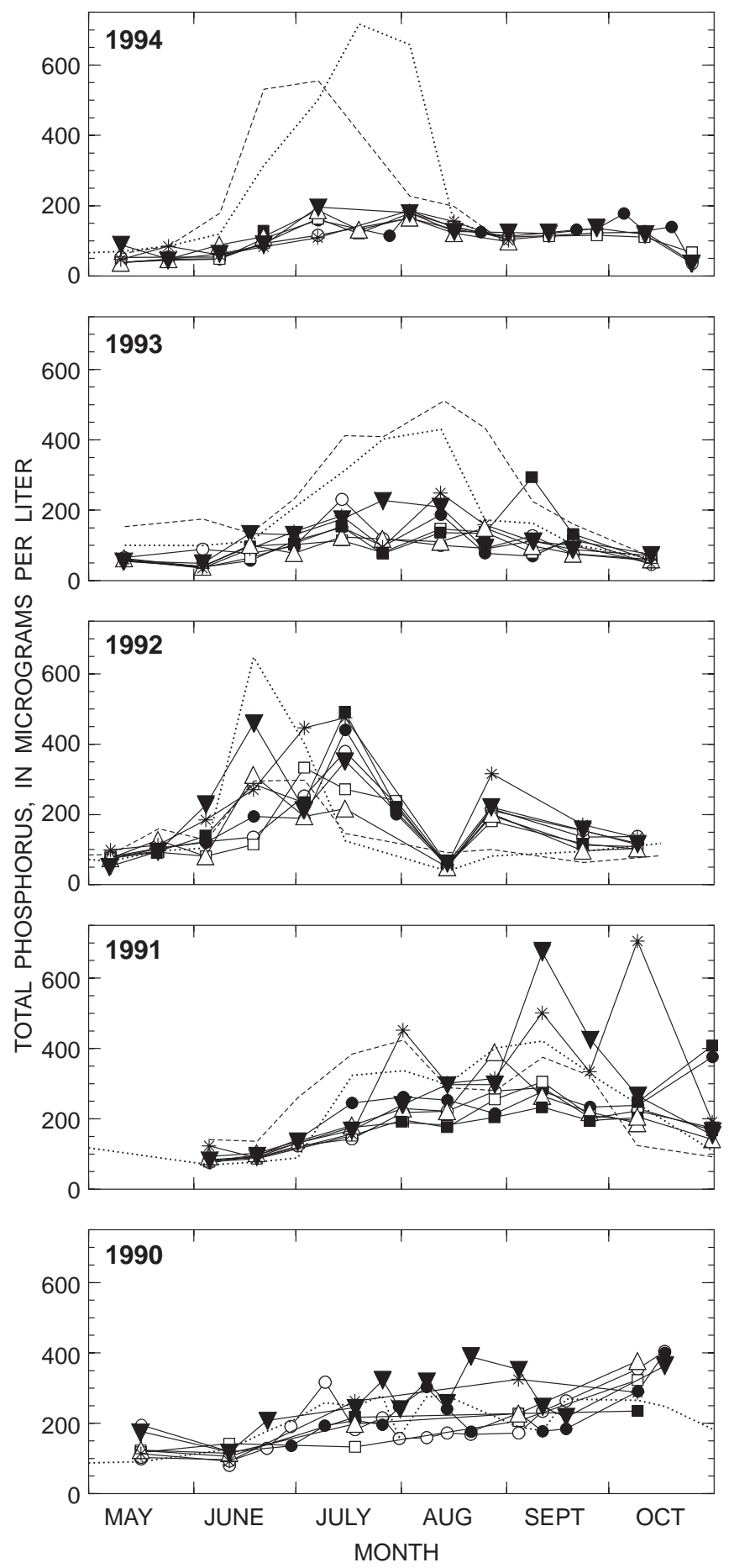

EXPLANATION

\begin{tabular}{|c|c|c|c|}
\hline \multicolumn{4}{|c|}{ Sampling location } \\
\hline & Agency Lake North & $\triangle$ & North Buck Island \\
\hline & Agency Lake South & घ & Pelican Marina \\
\hline O & Eagle Ridge & $\nabla$ & Shoalwater Bay \\
\hline$\square$ & Midlake & * & Wocas Bay \\
\hline - & Midnorth & & \\
\hline
\end{tabular}

Figure 25. Total phosphorus concentration at selected sites, Upper Klamath Lake, Oregon, May-October 1990-94.

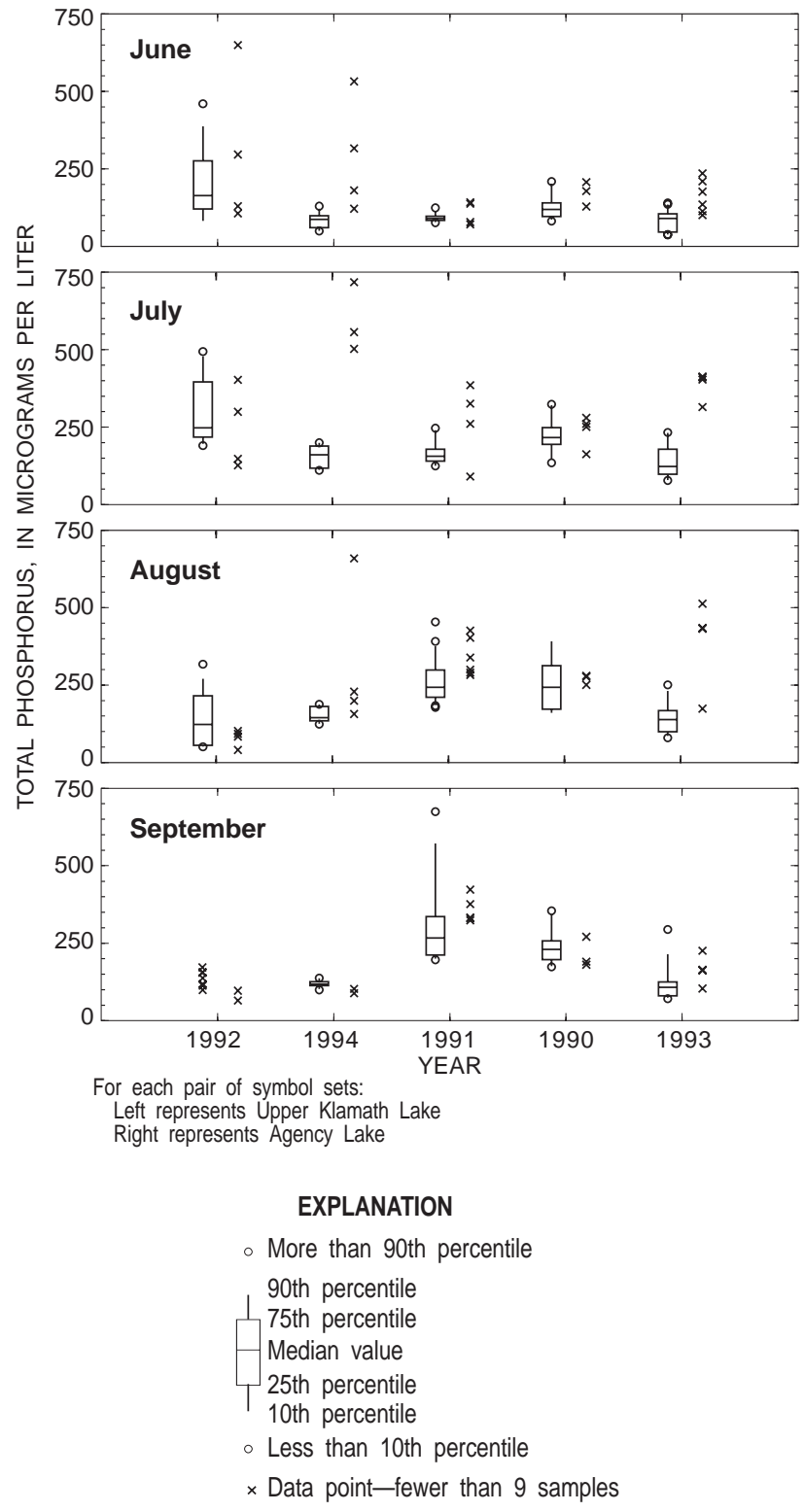

Figure 26. Frequency distributions of lakewide total phosphorus concentration data, Upper Klamath and Agency Lakes, Oregon, May through October, 1990-94. The years are ranked in order of increasing lake elevation.

the course of the season in 1992, 1993, and 1994, but total phosphorus distributions rose steadily through the season in 1990 and 1991. This pattern suggests that phosphorus loads during 1990 and 1991 differed markedly from those in the other 3 years. In Agency Lake the pattern is similar except that 1993 concentrations did not fall as quickly through August and September as they did in Upper Klamath Lake.

The discussion of chlorophyll- $a, \mathrm{pH}$, and dissolved oxygen established that the critical time period for examining the relation between declin- 
ing lake level and deteriorating water quality is early in the season, just before and during the first bloom of the year. Total phosphorus concentration in June is correlated with chlorophyll- $a$ concentration in June (fig. 27), suggesting that the strength of the first bloom is influenced by phosphorus concentration. In particular, the extremely high concentrations of phosphorus in June in both Upper Klamath and Agency Lakes coincided with an exceptionally heavy bloom in June in 1992.

In Upper Klamath Lake, higher June phosphorus concentrations were measured in 1992, the

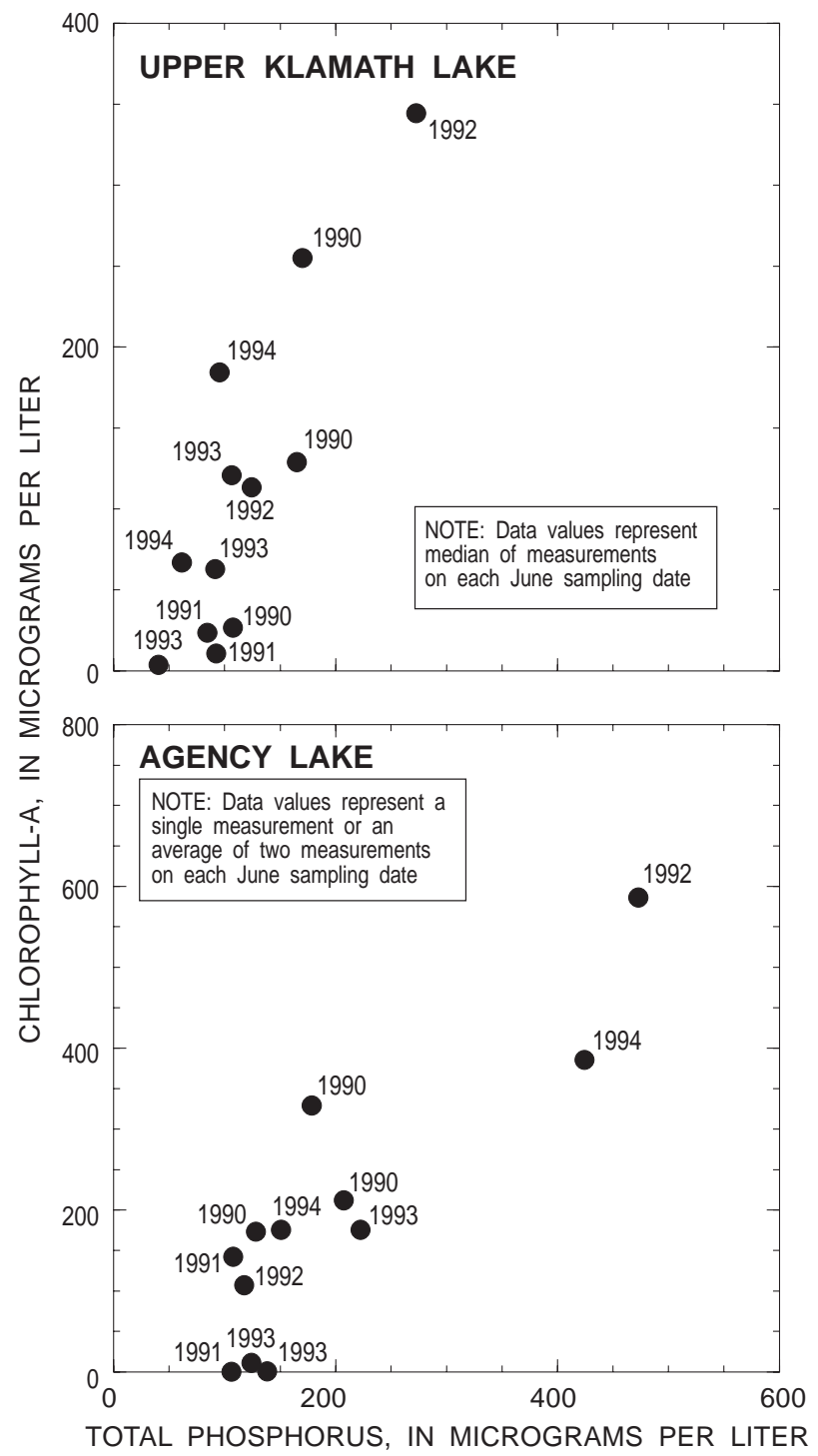

Figure 27. Relation of lakewide median chlorophyll-a concentration to lakewide median total phosphorus concentration, Upper Klamath and Agency Lakes, Oregon, June 1990-94. On two dates in 1990, only two sites were sampled in Upper Klamath Lake; for all other dates the number of sites contributing to the median value was at least seven. lowest-lake-level year, than in any other year. When this year is removed from the comparison, however, there is no conclusive relation between phosphorus concentration and lake level among the other 4 years (fig. 28). In Agency Lake, high phosphorus concentrations were measured in both 1992 and the next-highest-lake-level year, 1994, and June 1994 chlorophyll- $a$ measurements indicated a heavier bloom in Agency Lake than in Upper Klamath Lake (fig. 13). Given that 1992 had both an exceptionally high phosphorus concentration and an exceptionally heavy bloom, a possible connection between the low lake levels in 1992 and the high phosphorus concentration has important implications for water quality. In Agency Lake, which is shallower than Upper Klamath Lake, the connection may also apply to 1994.

In Upper Klamath Lake, phosphorus concentration was already higher at the beginning of June in 1992 than it was on the last June sampling date in other years (fig. 28). External loading from spring runoff could be an important factor in determining the phosphorus concentration in the lake at that time. An estimate of the significance of external loading, however, is beyond the scope of this report. Nonetheless, it is unlikely that external loading alone could account for the large increase in total phosphorus between 6/3/92 and 6/17/92, and internal loading almost certainly was important.

Internal loading of phosphorus by means of aerobic solubilization of sorbed phosphorus requires, at the very least, high $\mathrm{pH}$ (Stumm and Morgan, 1981) and sediment resuspension to be effective. A low lake level could enhance this process by increasing the bottom shear stress generated by a wind of a given magnitude. Theoretical estimates using Upper Klamath Lake bathymetry indicated that the bottom shear stress created by a $10 \mathrm{mph}$ wind at lake elevations as low as $4137 \mathrm{ft}$ could be very effective at resuspending sediment (an areally weighted shear stress of 3.0 dynes $/ \mathrm{cm}^{2}$ was calculated; Laenen and LeTourneau, 1996). The same analysis indicated that the areally weighted bottom shear stress at $4140 \mathrm{ft}$ elevation would be about one-half that at $4137 \mathrm{ft}$ (1.6 dynes/ $\mathrm{cm}^{2}$ ), but still at a value that could effectively resuspend sediment. Subsequent analyses during this study indicated that bottom shear stress decreases rapidly for lake elevations above $4140 \mathrm{ft}$, 


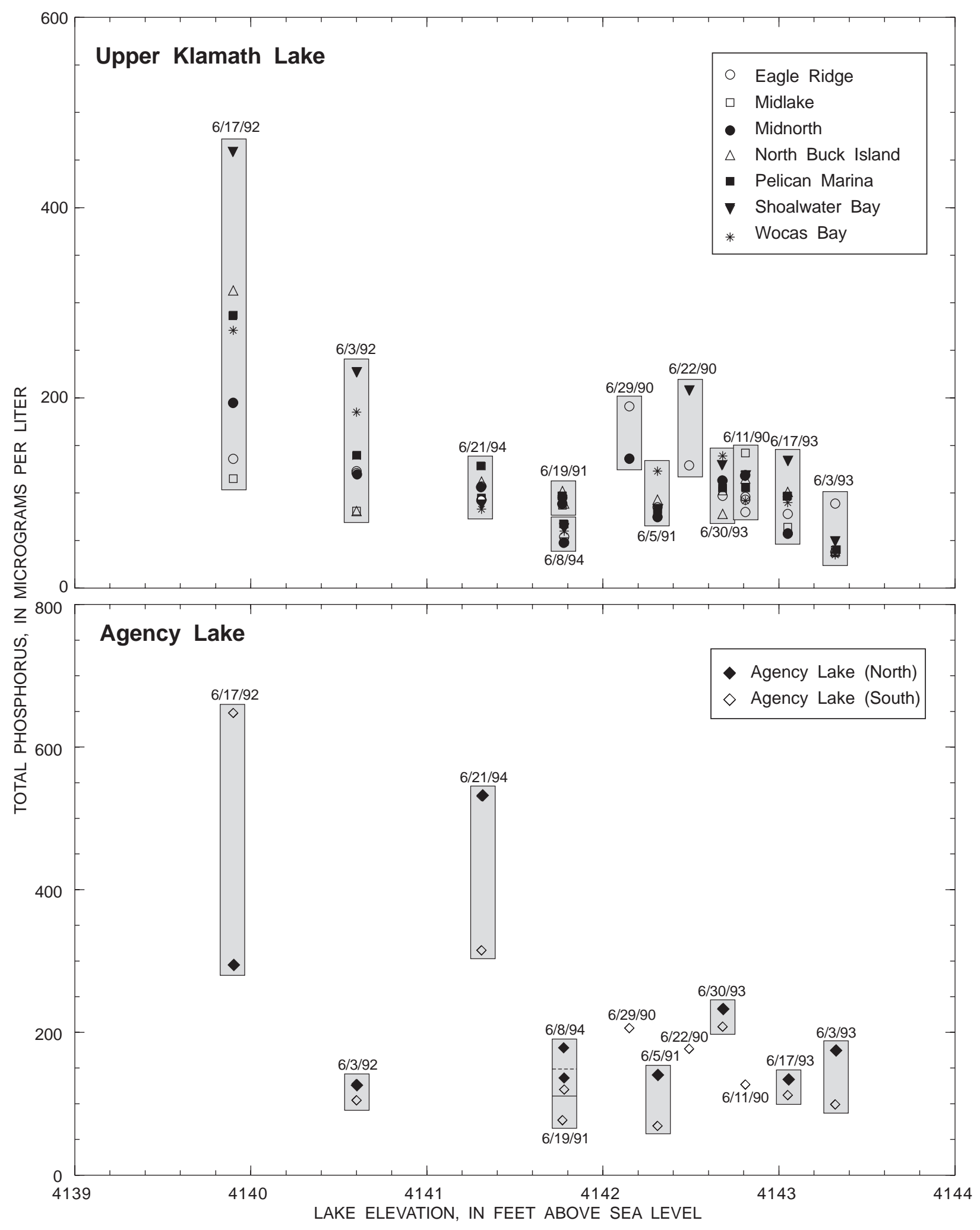

Figure 28. Relation of total phosphorus concentration to lake elevation, Upper Klamath and Agency Lakes, Oregon, June 1990-94. The corresponding sampling date is noted next to each group of data points. 
however, being approximately $0.35 \mathrm{dynes} / \mathrm{cm}^{2}$ at an elevation of $4141 \mathrm{ft}$.

These shear stresses cannot be translated to accurate phosphorus loading estimates, but they do suggest that internal loading would increase as lake level is lowered. The available data, however, are not sufficient to evaluate the relative importance of wind magnitude, high $\mathrm{pH}$, and lake level in determining internal phosphorus loading, and these are only the three most easily identified relevant variables. For example, in both Upper Klamath and Agency Lakes, high $\mathrm{pH}$ values were generated by blooms substantially lighter than that of 1992 (fig. 18); specifically, pH in June was very high in 1994 and 1990 as well as in 1992, but did not result in the same high phosphorus concentrations as in 1992, the lowest-lake-level year. Lake level could obviously have played a role, but wind data for 1992, 1993, and 1994 show that the frequency of windy days in June was highest in 1992 (fig. 29). It is impossible with this dataset to quantify the additional phosphorus concentration attributable to one variable or the other.

It is noteworthy that phosphorus concentration increased through the season (as lake level dropped) only during 1990 and 1991, with the result that, in August and September, phosphorus concentrations were lowest in both the lowestlake-level years (1992 and 1994) and the highest-lake-level year (1993). In Agency Lake, August 1993 concentrations were still high but dropped in September (fig. 26). This was curious because theoretical bottom stress calculations indicate that, given the right wind conditions, resuspension would increase dramatically at the lower lake levels of August and September, compared to earlier in the season. Winds were similar in July, August, and September in each of 1992, 1993, and 1994 (fig. 29), but important information-wind data for 1990 and 1991 — was not available. It is clear, however, that a critical set of circumstances is required to initiate internal loading of phosphorus, that lake level is only one of those circumstances, and that the relative importance of lake level compared to other variables is unknown.

Over most of the range in lake level represented, the data are not consistent with Hypothesis 7. The year of lowest lake level (1992) was exceptional in that concentrations of phosphorus in June

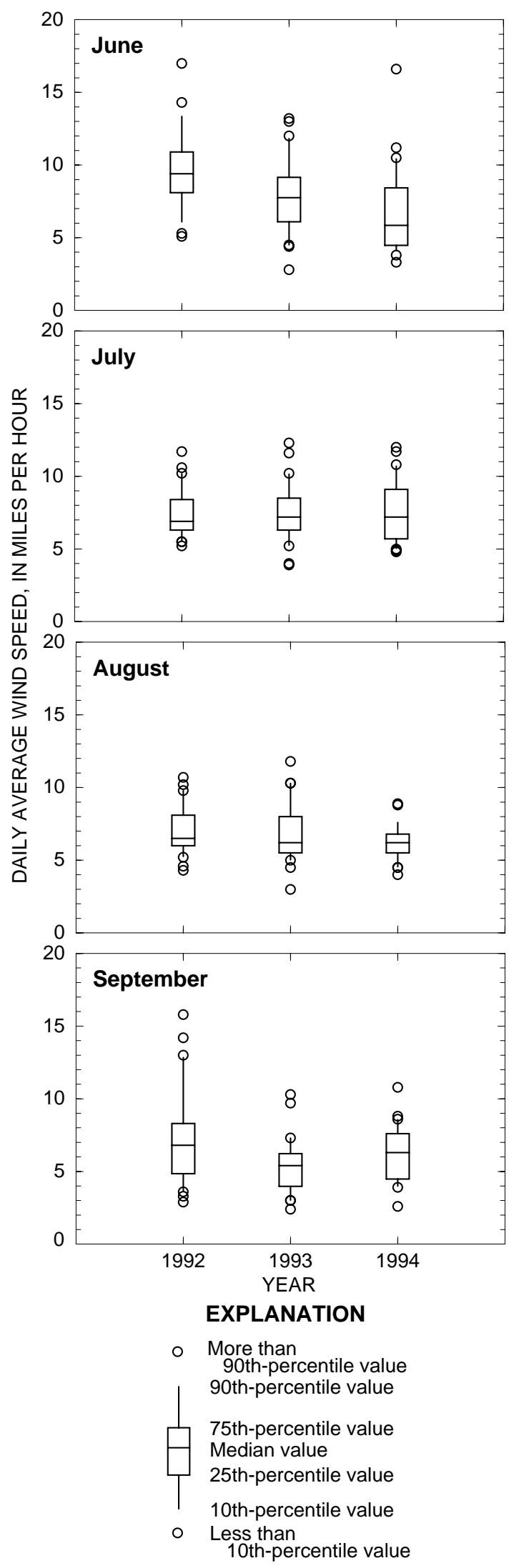

Figure 29. Frequency distribution of daily average wind speed recorded at Klamath Falls airport, Oregon, June 1992-94. 
were very high relative to the other years. It is possible that in that year, a synergistic combination of low lake level with other factors resulted in very high phosphorus concentrations. Later in the year, however, in September, concentrations were highest in 1990 and 1991, and in 1991 the concentrations were even higher in Upper Klamath Lake than they were in June of 1992. In September, phosphorus concentrations were lowest in both the lowest-lake-level years (1992 and 1994) and the highest-lake-level year (1993).

\section{Water Temperature}

A general statement of the hypothesis relating water temperature to lake level is as follows:

Hypothesis 8: Year-to-year differences in the rate of spring warming of the lake are related to year-to-year differences in lake level, such that water temperature increases more slowly when the lake level is higher.

The median surface water temperature associated with each of the depth-profile sampling dates indicates that the lake was warmer in 1992 and 1994 than in the other 3 years during May and the early part of June (fig. 30). Unfortunately, pro- file data were not available for May of 1991, but it is useful to recall that, through May, 1994 was closer to 1991 than to 1992 in terms of the volume of water in the lake. It is unlikely, therefore, that the early spring temperature of the lake is significantly affected by the volume of water in the lake. More likely, a combination of climatic factors, as well as the temperature of inflows and groundwater inputs, determines the overall temperature.

Hypothesis 8 is, however, designed to test the rate at which the lake temperature changes, not its absolute magnitude. This is a difficult hypothesis to test directly because it involves the derivative of temperature rather than temperature itself. It is easier to test the hypothesis indirectly by examining the relation between weather and temperature in the lake. One climatic variable, minimum and maximum daily air temperature, was available to investigate this relation. The frequency with which the depth profiles were taken was not adequate to closely examine the relation between temperature in the lake and air temperature, but the 1-m depth hourly records, while sporadic, do have the frequency of sampling required to capture day-to-day changes in water temperature. These records are available from only a few locations, but water temperature was found to be highly correlated around the lake, so that data

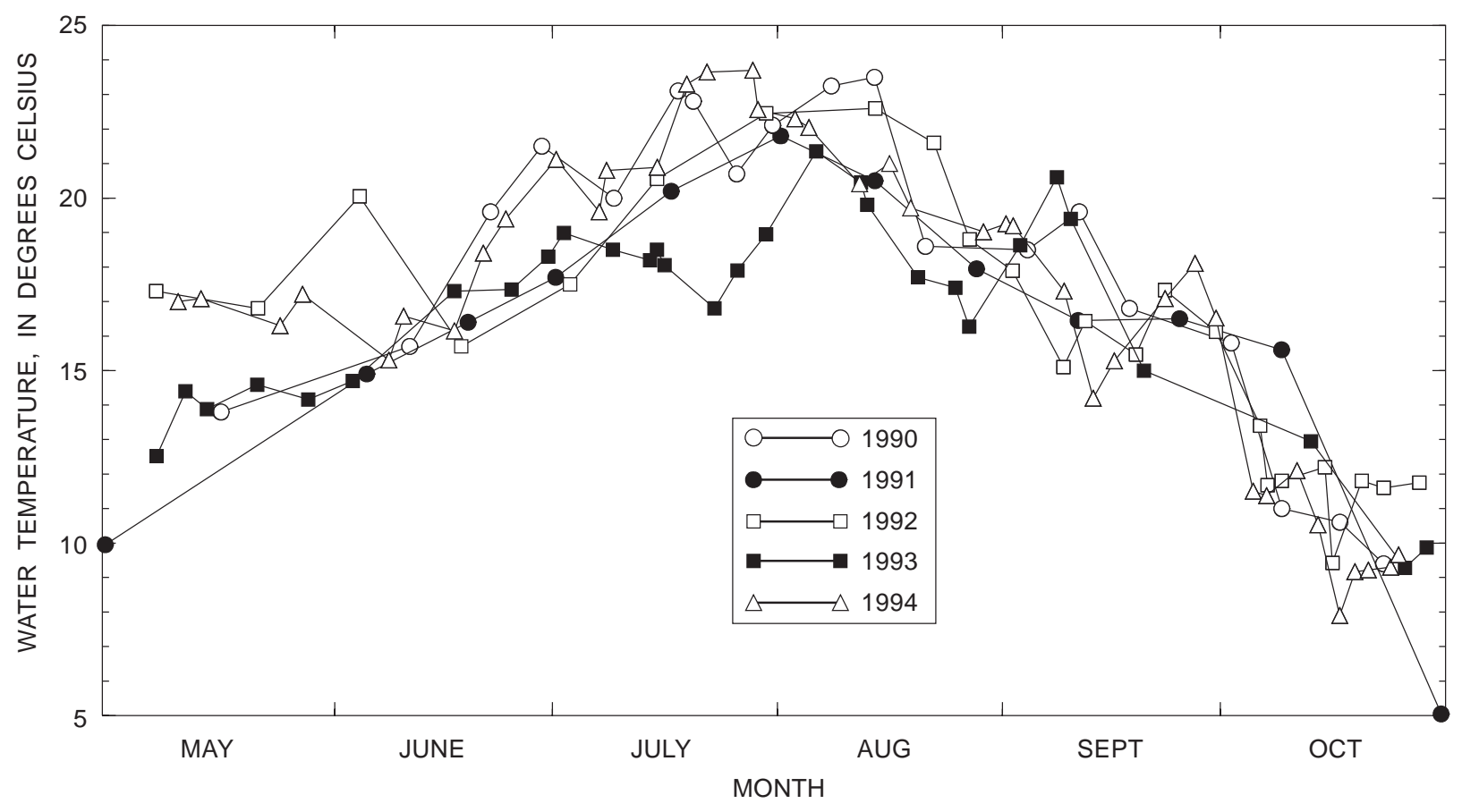

Figure 30. Lakewide median of depth-profile water temperature data, Upper Klamath and Agency Lakes, Oregon, May-October 1990-94. Measurements from all depths were included in the median. 
from a single station will provide a good indication of the lakewide response to air temperature.

The daily average of the available water temperature records from Midnorth and Shoalwater Bay were plotted with the average of the daily maximum and minimum air temperature (fig. 31). The air temperature data have been smoothed with a 7-day running average. It is quite clear from these records that air temperature exerts a strong influence on the temperature in the lake because the daily to weekly fluctuations in the 1-m water temperature records parallel the air temperature, with a lag of a few days. This does not mean that air temperature determines the absolute temperature in the lake; the absolute temperature is determined by the overall heat budget, of which air temperature is only one component.

Given the strong correspondence between fluctuations in lake temperature and air temperature, it is unlikely that a slightly deeper lake would have a substantially different response time than a slightly shallower one. Indeed, there is no evidence of increased "thermal inertia" in the 1993 records, because the response time during that year appears to be about the same as in the other two. Thus, the data do not support Hypothesis 8, and it is unlikely that a higher lake level is effective in slowing down the spring warming of the lake.

\section{HYPOTHESES RELATING WATER QUALITY TO CLIMATIC VARIABLES}

The connection between algal growth, $\mathrm{pH}$, and dissolved oxygen was established in the previous section. It was also established that algal growth shows an apparent relation with lake level, particularly in terms of the timing of the first bloom, and that the timing of the first bloom determines, in large part, water quality conditions (especially $\mathrm{pH}$ ) in June. In that section, however, the issue of causality was not addressed. Establishing an apparent relation with lake level does not establish a cause-and-effect relation.

Investigating the dependence of water-quality variables on independent variables other than lake level provides important perspective. The independent variables discussed below-air temperature and an index derived from cloud cover data-also show an apparent relation with June algal growth, both the timing of the bloom and June chlorophyll- $a$ concentration. Because these variables are, to some extent, correlated with lake level, there is no way to separate their relative causal effects on water quality. Lake level and climate variables may act concurrently or in conjunction with each other to affect water quality, or one of them may be a real causal factor whereas the other is not.

The hypotheses that relate air temperature to June algal growth can be stated as follows:

Hypothesis 9: Year-to-year differences in the timing of the first bloom are related to year-to-year differences in the number of degree-days between April 1 and May 15, such that the bloom occurs earlier at a higher number of degree-days.

\section{Hypothesis 10: Year-to-year differences in June chlorophyll-a concentration are related to year-to-year differences in the number of degree-days between April 1 and May 15, such that concentrations are higher at a higher number of degree-days.}

Air temperature was available for the entire period of analysis, was collected with daily resolution, and therefore provides a good indication of the relative warmth of the spring of each year. A comparison of overlapping air and water temperature data (both the biweekly profiles and the hourly $1-\mathrm{m}$ records) showed that the air temperature data was probably a better indicator of the relative differences in water temperature between years than was the water temperature data itself, because air temperature was measured daily. Therefore Hypotheses 9 and 10 also address the dependence of early spring algal growth on water temperature.

A cumulative number of degree-days from April 1 to May 15 was calculated from the average of the minimum and maximum daily temperature to use as a measure of the integrated heat put into the system over that time period. The number of days to the first bloom, using a $20 \mu \mathrm{g} / \mathrm{L}$ chlorophyll- $a$ criterion, and the median June chlorophyll- $a$ concentration, were then plotted against the cumulative degree-days in figs. 32 and 33, respectively. The "error bars" shown in figure 33 are the values of the 10th and 90th percentiles of the June distributions. 

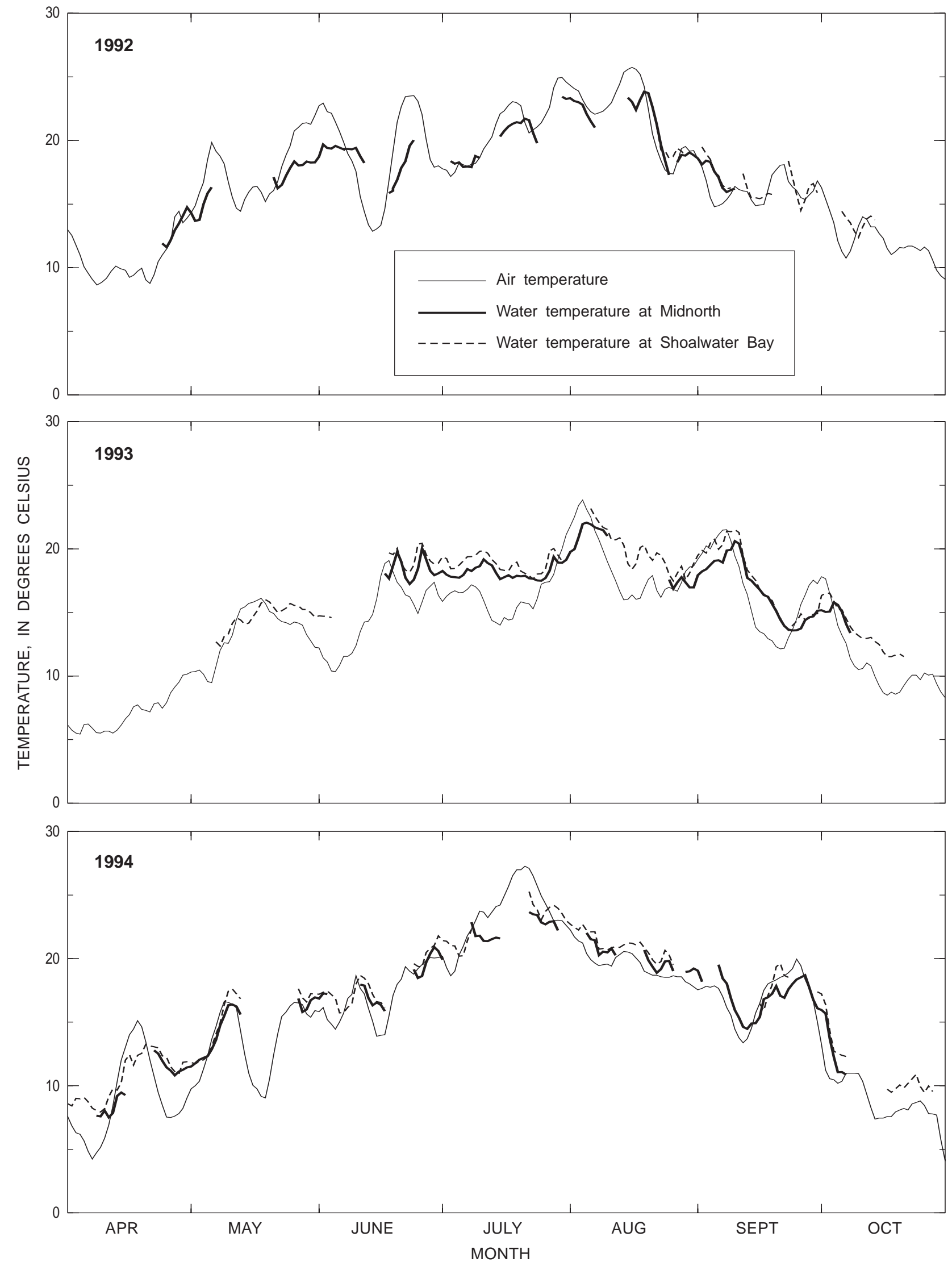

Figure 31. Daily average water temperature from hourly records at Midnorth and Shoalwater Bay superimposed on the average of the daily maximum and minimum air temperatures recorded at Klamath Falls airport, Upper Klamath Lake, Oregon, April-October, 1992-94. The air temperature has been smoothed with a 7-day running average. 


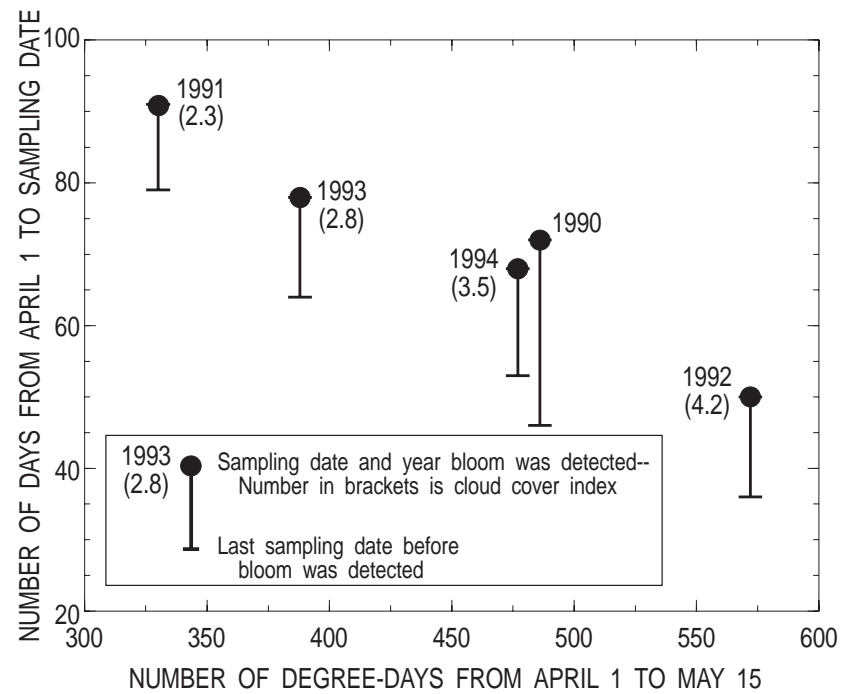

Figure 32. Relation of number of days from April 1 to the sampling date on which the algal bloom was first detected to the number of degree-days from April 1 to May 15, Upper Klamath Lake, Oregon, 1990-94. The criterion used for bloom detection was a chlorophyll-a concentration of 20 micrograms per liter or higher. The number of degree-days is calculated by integrating the daily temperature values over the time period of April 1 to May 15. The daily temperature values are an average of the daily minimum and maximum temperature values.

Insolation data were not available, but cloud cover data collected at the Klamath Falls airport were. These data consisted of a numerical value from 1 to 7, indicating conditions ranging from cloudy to sunny. An average cloud cover index was calculated from these data by summing the daily values and dividing by the number of days. Cloud cover data were not available for May 1990; therefore an index could not be calculated for that year. The cloud cover index corresponding to the same time period over which degree-days were calculated is noted on the figures next to the corresponding year.

The year that did not fit the pattern with lake level (fig. 12), 1991, appears to fit the pattern with degree-days well (fig. 32), and it may be that particularly cold weather arrested what otherwise would have been an early bloom start in that year (1991 was the year in which chlorophyll- $a$ rose to $20 \mu \mathrm{g} / \mathrm{L}$ early, and then fell again to low levels). The cloud cover index corresponds well with the

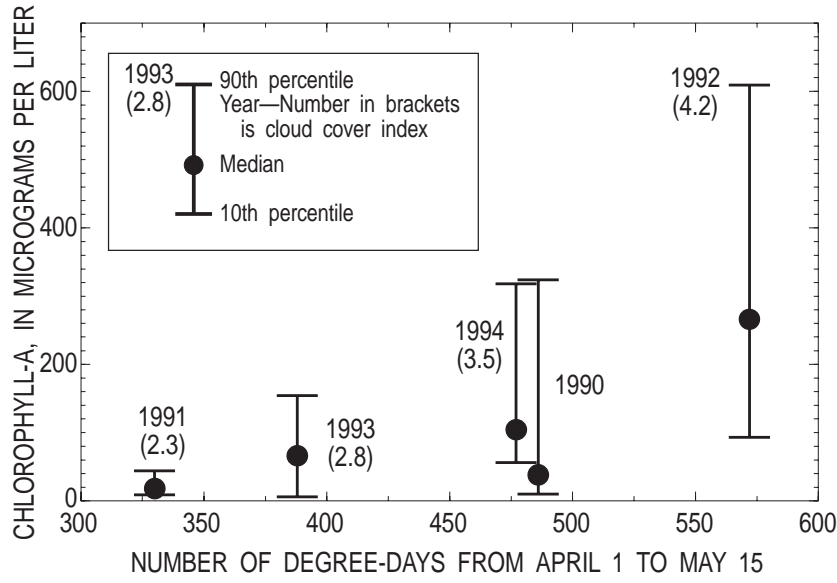

Figure 33. Relation of median June chlorophyll-a concentration to the number of degree-days from April 1 to May 15, Upper Klamath and Agency Lakes, Oregon, 1990-94. The number of degree-days is calculated by integrating the daily temperature values over the time period of April 1 to May 15. The daily temperature values are an average of the daily minimum and maximum temperature values.

number of degree-days, with a higher number of degree-days being associated with more sunshine and a higher index. The data are consistent with Hypothesis 9, but this conclusion must be tempered by the imprecision in the timing of the detection of $20 \mu \mathrm{g} / \mathrm{L}$ that was caused by the biweekly sampling.

The data presented in figure 33 simply compare the distributions of June chlorophyll- $a$ by year, in effect ranking the years by accumulated degreedays rather than by lake level as was done in figure 13. By degree-days, the 5 years rank from highest to lowest as 1991, 1993, 1994, 1990, and 1992. There is a relatively even distance in degree-days between most of the years, with the exception that 1994 and 1990 rank approximately the same. Except for 1990 , the median values of the distributions increase with an increasing number of degree-days and with de- creasing cloud cover. As discussed previously, there is a possibility that June chlorophyll- $a$ concentration was underestimated in 1990. The overall progression from lower to higher June chlorophyll- $a$ distributions as the number of degree-days increases indicates that the data are consistent with Hypothesis 10. 


\section{REFERENCES CITED}

Barbiero, R.P., 1993, A contribution to the life history of the planktonic cyanophyte, Gloeotrichia echinulata: Archives für Hydrobiologia, v. 127, p. 87-100.

Barbiero, R.P., and Kann J., 1994, The importance of benthic recruitment to the population development of Aphanizomenon flos-aquae and internal loading in a shallow lake: Journal of Plankton Research, v. 16, no. 11, p. 1581-1588.

Bellerud, B., and Saiki, M.K., 1995, Tolerance of larval and juvenile Lost River and shortnose suckers to high $\mathrm{pH}$, ammonia concentration, and temperature, and to low dissolved oxygen concentration-Draft final report: Dixon, California, National Biological ServiceCalifornia Pacific Science Center, 103 p.

Bortleson, G.C., and Fretwell, M.O., 1993, A review of possible causes of nutrient enrichment and decline of endangered sucker populations in Upper Klamath Lake, Oregon: U.S. Geological Survey Water-Resources Investigations Report 93-4087, $31 \mathrm{p}$.

Bowie, G.L., Mills, W.B., Porcella, D.B., Campbell, C.L., Pagenkopf, J.R., Rupp, G.L., Johnson, K.M., Chan, P.W.H., and Gherini, S.A., 1985, Rates, constants, and kinetics formulations in surface water quality modeling ( $2 \mathrm{~d}$ ed.): U.S. Environmental Protection Agency, Office of Research and Development, Environmental Research Laboratory, $455 \mathrm{p}$.

Buettner, Mark, and Scoppettone, G.G., 1990, Life history and status of catostomids in Upper Klamath Lake, Oregon: Reno, Nevada, U.S. Fish and Wildlife Service, National Fisheries Research Center, Completion Report, 108 p.

Carmichael, W.W., 1986, Algal toxins: Advances in Botanical Research, v. 12, p. 47-101.

Davis, J.C., 1975, Minimal dissolved oxygen requirements of aquatic life with emphasis on Canadian species-A review: Journal of the Fisheries Research Board of Canada, v. 32, no. 12 , p. 2295-2331.

Falter, M.A., and Cech, J.J., 1991, Maximum pH tolerance of three Klamath Basin fishes: Copeia, v. 4, p. 1109-1111.

Gentile, J.H., and Maloney, T.E., 1969, Toxicity and environmental requirements of a strain of Aphanizomenon flos-aquae: Canadian Journal of Microbiology, v. 15, p. 165-173.

Jacoby, J.M., Lynch, D.D., Welch, E.B., and Perkins, M.A., 1982, Internal phosphorus loading in a shallow eutrophic lake: Water Resources Research, v. 16, p. 911-919.
Jensen, H.S., and Anderson, F.O., 1992, Importance of temperature, nitrate, and $\mathrm{pH}$ for phosphate release from aerobic sediments of four shallow, eutrophic lakes: Limnology and Oceanography, v. 37, p. 577-589.

Kann, Jacob, and Falter, C.M., 1987, Development of toxic blue-green algal blooms in Black Lake, Kootenai County, Idaho: Lake and Reservoir Management, v. 3, p. 99-108.

Laenen, Antonius, and LeTourneau, A. P., 1996, Upper Klamath Basin nutrient-loading study-Estimates of wind-induced resuspension of bed sediment during periods of low lake elevations: U.S. Geological Survey Open-File Report 95-414, 11 p.

Monda, D.P., and Saiki, M.K., 1994, Tolerance of larval Lost River sucker to high $\mathrm{pH}$, ammonia concentration, and temperature, and to low dissolved oxygen concentration: Dixon, California, National Biological Service-National Fish Contamination Research Center, 67 p.

Monda, D.P., and Saiki, M.K., 1993, Tolerance of juvenile Lost River and shortnose suckers to high $\mathrm{pH}$, ammonia concentration, temperature, and to low dissolved oxygen concentration, chap. 8 in Campbell, S. G., ed., Environmental research in the Klamath Basin, Oregon: Bureau of Reclamation 1992 Annual Report, R-93-16, $341 \mathrm{p}$.

Mortenson, E., Jeppesen, E., Sondergaard, M., Nielsen, L.K., eds., 1994, Nutrient dynamics and biological structure in shallow freshwater and brackish lakes: Boston, Kluwer Academic Publications, p. 267276.

Repavich, W.M., Sonzogni, W.C., Standridge, J.H., Wedepohl, R.E., and Meisner, L.F., 1990, Cyanobacteria (blue-green algae) in Wisconsin waters-Acute and chronic toxicity: Water Resources Research, v. 24, no. 2, p. 224-231.

Simon, D.C., Markle, D.F., and Hoff, G.R., 1995, Larval and juvenile ecology of Upper Klamath Lake suckers: Annual Report submitted to Klamath Project, Bureau of Reclamation.

Stumm, W., and J.J., Morgan, 1981, Aquatic Chemistry ( 2 d ed.): New York, Wiley and Sons, chap. 10, p. 599-684.

U.S. Environmental Protection Agency, 1986, Quality criteria for water 1986: EPA 440-5-86-001, unpaginated.

Welch, E.B., DeGasperi, C.L., and Spyridakis, D.E., 1988, Sources for internal phosphorus loading in a shallow lake: Verhandlung Internationale Vereinigung Limnologie, v. 23, p. 307-314. 